\title{
Atlantic Canadian Representation in the National Gallery of Canada's Biennial Exhibitions of Canadian Art (1953-1968)
}

\author{
by \\ Suzanne A. Crowdis, BFA (Concordia University, 2004) \\ School for Studies in Art and Culture, Department of Art History \\ A thesis submitted to the Faculty of \\ Graduate Studies and Research in partial fulfillment of \\ the requirements for the degree of \\ Master of Arts \\ in Art History
}

Carleton University

OTTAWA, Ontario

(C) 2010, Suzanne A. Crowdis 


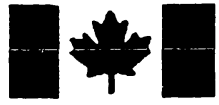

Library and Archives

Canada

Published Heritage

Branch

395 Wellington Street

Ottawa ON K1A ON4

Canada
Bibliothèque et

Archives Canada

Direction du

Patrimoine de l'édition

395, rue Wellington

Ottawa ON K1A ON4

Canada
Your file Votre référence

ISBN: 978-0-494-71604-5

Our file Notre référence

ISBN: 978-0-494-71604-5

\section{NOTICE:}

The author has granted a nonexclusive license allowing Library and Archives Canada to reproduce, publish, archive, preserve, conserve, communicate to the public by telecommunication or on the Internet, loan, distribute and sell theses worldwide, for commercial or noncommercial purposes, in microform, paper, electronic and/or any other formats.

The author retains copyright ownership and moral rights in this thesis. Neither the thesis nor substantial extracts from it may be printed or otherwise reproduced without the author's permission.
AVIS:

L'auteur a accordé une licence non exclusive permettant à la Bibliothèque et Archives Canada de reproduire, publier, archiver, sauvegarder, conserver, transmettre au public par télécommunication ou par l'Internet, prêter, distribuer et vendre des thèses partout dans le monde, à des fins commerciales ou autres, sur support microforme, papier, électronique et/ou autres formats.

L'auteur conserve la propriété du droit d'auteur et des droits moraux qui protège cette thèse. $\mathrm{Ni}$ la thèse ni des extraits substantiels de celle-ci ne doivent être imprimés ou autrement reproduits sans son autorisation.
In compliance with the Canadian Privacy Act some supporting forms may have been removed from this thesis.

While these forms may be included in the document page count, their removal does not represent any loss of content from the thesis.
Conformément à la loi canadienne sur la protection de la vie privée, quelques formulaires secondaires ont été enlevés de cette thèse.

Bien que ces formulaires aient inclus dans la pagination, il n'y aura aucun contenu manquant.

\section{Canadä}




\begin{abstract}
This thesis examines Atlantic Canadian representation in the eight biennial exhibitions of Canadian art organized by the National Gallery of Canada. From 1953 to 1968, the biennial series surveyed contemporary Canadian art using various selection methods to discover new developments. Regional committees were formed to identify and alert biennial exhibition organizers to innovative activity and artists. Organizers also personally toured Atlantic artists' studios, yet the region was consistently inadequately represented in the series' exhibitions and touring schedules. When Atlantic art was exhibited, it was negatively characterized as unequivocally representational and traditional.

I argue that Atlantic Canada's frequent under-representation and characterization in the series was affected by several factors. Provincial governments and several individuals in the region, for example, diligently cultivated a traditional identity and can be held responsible for promoting an anti-modern image. Also, the National Gallery's growing involvement in the international art community impacted regional representation in the series.
\end{abstract}




\section{Acknowledgements}

I would particularly like to thank my advisors, Brian Foss and Carol Payne, for encouraging me throughout this process. I am grateful for their guidance, careful reflection, and keen editing. Their enthusiasm for my research has inspired me to continue asking questions and go on writing.

The archival research I conducted would not have been possible without the assistance of several individuals. Cyndie Campbell at the National Gallery of Canada Library and Archives was instrumental in providing access to biennial exhibition material. She assured me that a great deal of archival material existed on the biennial series before I even arrived in Ottawa, helping me solidify my intent to study these exhibitions. My time at Nova Scotia Archives and Records Management was most efficient thanks to the kind and thorough staff who assisted me in my research preparations and eagerly facilitated my visit.

The encouragement and assistance of my APAGA colleagues is also appreciated. Bruce Johnson and Marie Maltais kindly sent me exhibition catalogues and information. John Murchie thoughtfully steered my topic in the right direction when I began thinking about my thesis. Much thanks to each of you and the curators who cheered me on.

My heartfelt appreciation is sent to my family and friends for their patience, good humour, and wisdom. They may not have realized how important they (and at times, their absence) were to the process, but I could not have completed this thesis without their support and love. My partner Paul helped me navigate the excitement and worries that accompanied this new project, delighted in my triumphs, and reliably lifted my spirits. Thank you. 


\section{Contents}

Abstract

Acknowledgements iii

Contents iv

$\begin{array}{lr}\text { Introduction } & 1\end{array}$

Chapter 1. A Survey of the Visual Arts Infrastructure 16 in Atlantic Canada from 1955 to 1968

Chapter 2. The Biennial Exhibitions of Canadian Art and 54 Atlantic Canadian Representation (1953-1957) and the Demise of the Biennial Exhibitions of Canadian Art (1959-1968)

Conclusion

Appendix I

Bibliography 


\section{Introduction}

When the topic of Canadian survey exhibitions arises, Atlantic Canadian artists and cultural workers are quick to cite the region's past under-representation in National Gallery of Canada shows. Atlantic Canada's low representation in large-scale survey exhibitions, such as the National Gallery of Canada's Songs of Experience (1986) and the more recent Canadian biennial in 1989, still has the ability to generate heated discussion on the East Coast twenty years later. ${ }^{1}$ Was there a legacy of Atlantic Canadian underrepresentation in similar exhibitions? The National Gallery of Canada's biennial exhibitions of Canadian art dating from the 1950s and 1960s provide a particularly effective art historical case study for addressing that question.

From 1953 to 1968, the National Gallery organized and circulated eight biennial exhibitions of Canadian art. The series attempted to survey the currents of contemporary Canadian painting, from coast to coast, and employed different methods to do so most effectively. Exhibition mandates, regional jury members and curators changed over those years, as did the National Gallery itself, which led to varying amounts of Atlantic Canadian art being shown. In each exhibition, however, the region with the fewest works was Atlantic Canada.

As Charles Comfort writes in the foreword to the Fifth Biennial Exhibition of

Canadian Painting's catalogue:

In Canada, we place considerable value upon these exhibitions, in the light of what each successive survey reveals to us in the regional and individual development, and in the discovery of new trends and new directions. $^{2}$ 
But what did each successive survey reveal about Atlantic Canadian art? What did these exhibitions communicate about the region to the rest of Canada and the international art community? How was Atlantic Canadian art production positioned in relation to art produced in major urban centres during the mid-twentieth century? How was Atlantic Canadian production characterized and represented on this national platform and who was responsible for promoting and circulating myths about Atlantic Canadian art and, by extension, Atlantic Canadian identity? These questions drove my thesis research.

I was also curious to see if characterizations communicated in biennial exhibition literature were byproducts of Atlantic Canadian efforts. To answer this question, I explored the motivation for conceiving and promoting a traditional, anti-modern perspective about New Brunswick, Nova Scotia, Prince Edward Island, and Newfoundland and Labrador. Several prominent Atlantic Canadians were instrumental in actively branding the region, especially in the biennial exhibition era. I found that these individuals played significant roles in regional myth-making and influenced the subsequent critical esteem in which Atlantic visual art was held at the time. If politics within the region dictated this stance, why would we expect anything else from civil servants in Ottawa? Did artists combat this stereotype? Were biennial exhibition organizers aware of the hurdles Atlantic Canadian artists faced in their cultural development and their promotion?

Using a series of national exhibitions as a case study, this thesis examines regional inclusion, studies the history of Atlantic Canadian art infrastructure, and considers the characterization of the region and its art in the mid-twentieth century. Rather than merely recognizing regionally imbalanced representation or cursorily 
suggesting why the National Gallery of Canada may have misunderstood and misrepresented Atlantic Canada in its biennial exhibition series (as Natalie LimbosBomberg and John Murchie have), ${ }^{3}$ I suggest that if Atlantic Canadian visual arts were indeed under-represented in national survey exhibitions and inaccurately portrayed as representational and 'traditional', cultural producers and provincial governments from within the region share some of the burden of responsibility for this biased history. On the other hand, pointing to the complex nature of representing regions, I offer evidence that the arts infrastructure in Atlantic Canada, although varied among the four provinces, was significant. The artists working there were often highly trained, serious, and worthy of greater investigation and acknowledgement in the series.

My interest in this topic stems from my personal link to Atlantic Canada. Growing up in Nova Scotia, one is exposed from a young age to the oft-heard criticisms of Ottawa's lack of understanding about the area's needs and its ignorance of the breadth and value of its cultures and cultural expressions. I was interested in how the National Gallery of Canada's biennial exhibitions of Canadian art advanced or contradicted this potentially myopic view of federal institutions and their response to the region. Did this exhibition series bolster or destabilize the popular regional sentiment that Ottawa-based institutions are historically unresponsive or indifferent to Atlantic Canada? My cultural background both tempered my research and provided me with personal insights into the questions outlined above.

I was especially aware of the need to remain objective, make no assumptions, and avoid demonizing Ottawa or automatically assigning judgment to any regional underrepresentation I found in my investigation. I noticed during my research on this 
exhibition series that many other so-called "peripheral" communities were also omitted. Research has yet to be done, for example, on Northern Canada's complete absence from the Biennial Exhibitions of Canadian Art.

I note the distinction between the terms 'Maritimes' and 'Atlantic Canada', noninterchangeable definitions whose subtleties are well known within the region but seem to cause confusion among some outside the region, including biennial organizers and jury members. 'Atlantic Canada' includes all four provinces with substantial borders on the Atlantic Ocean including New Brunswick, Nova Scotia, Prince Edward Island and Newfoundland and Labrador (referred to as such since 1964 and constitutionally recognized in 2001 as the province's official name, incorporating its island and mainland segments). The Maritime region comprises all provinces but Newfoundland and Labrador, thus excluding a major geographical and social portion of the region.

\section{State of the Literature}

A survey of the scholarly literature related to the National Gallery of Canada's biennial exhibitions of Canadian art series reveals few sources on my specific topic. "The Ideal and the Pragmatic: The National Gallery of Canada's Biennial Exhibitions of Canada Art, 1953-1968", by Nathalie Limbos-Bomberg, is the most useful study of the biennial exhibitions of Canadian art available. Limbos-Bomberg skillfully narrates the history of the program by examining and presenting primary source material drawn from the National Gallery of Canada's Library and Archives and the Library and Archives

Canada. Her account of the program relies on the Gallery's archival exhibition files and exhibition catalogue essays, Jean Sutherland Boggs' history of the National Gallery of Canada, as well as the personal papers of former National Gallery trustee Lawren S. 
Harris, and directors H.O. McCurry and Charles Fraser Comfort. It also utilizes Robin Endres and John Porter's Marxist perspectives and elite theory, respectively, for a theoretical framework which focuses on the relationship of the arts and the state. ${ }^{4}$

The detailed history in "The Ideal and the Pragmatic" of the biennial series provided a point of departure for my own thesis. I explore a particular aspect - Atlantic Canadian representation - of the biennial exhibition series in depth and do not recount its entire general history. I address how the series' development and execution has affected, characterized, and promoted the identity of a region. Unlike Limbos-Bomberg, who discusses regional inclusion solely in quantitative terms (for example, as percentages of work exhibited and purchased during the series and the time each exhibition spent touring each area of Canada), this thesis studies Atlantic Canadian inclusion in the biennials against a complex backdrop of provincial art infrastructure.

Douglas Ord's The National Gallery of Canada provides an in-depth examination of the National Gallery of Canada's history. Particularly useful for this thesis were Parts Two of Ord's monograph- "The Field Before (1910-65)" - and Three - "The Evolution of a Style (1966-90)", which followed the development of the National Gallery during the biennial exhibition years. ${ }^{5}$ Ord's depiction of seminal figures such as Eric Brown, H.O. McCurry, and Alan Jarvis has informed this thesis as well.

Texts which contextualize the origins of the biennial exhibitions and demonstrate the National Gallery's contribution to building Canadian identity include Paul Litt's The Muses, the Masses and the Massey Commission, Joyce Zemans" "Establishing the Canon: Nationhood, Identity and the National Gallery's First Reproduction Programme of 
Canadian Art," Maud Brown's Breaking Barriers, and Lynda Jessup's “Bushwackers in the Gallery: Antimodernism and the Group of Seven". 6

The Muses, the Masses and the Massey Commission explicitly portrays the Canadian political and cultural climate in the years leading up to development of the Royal Commission on National Development in the Arts, Letters and Sciences commonly know as the Massey Commission - in 1949. Litt's study recounts the events leading to the 1951 publication of its report on varied aspects of Canadian culture. In presenting the Commission in its historical context - particularly in Chapters 6 and 9: "Liberal Humanism" and "Cultivating the Hinterland", respectively - Litt articulates nationalistic ideologies of pride and unity operating of this time and documents the vital role federal institutions such as the National Gallery played in promoting them.

Zemans' case study of the National Gallery's influential role and wide-reaching capacity for shaping national identity and national consciousness is important for this author's thesis. Zemans demonstrates the Gallery's ambition to foster a Canadian culture and national identity and documents the lengths the Gallery went to in order to secure a nationalistic role. Maud Brown's discussion of her husband's work and legacy in Breaking Barriers positions the National Gallery's role in nation-building within the earliest years of the Gallery's development as an important federal tool for disseminating culture and bolstering identity. This information and the perspective it provides regarding the National Gallery's early educational efforts and its history as creator and repository of Canadian identity is valuable to a study of the institution.

Lynda Jessup's discussion of the National Gallery of Canada's hegemonic portrayal of Canadian culture in "Bushwackers in the Gallery: Antimodernism and the 
Group of Seven" provides an understanding of the National Gallery's views on Canadian art in the years leading up to and following the biennial exhibitions of Canadian art. Jessup emphasizes that the art the National Gallery (Eric Brown) championed as "Canadian" - the Group of Seven's work - was in fact Ontario regionalism, highly promoted and held up as exemplary of the whole nation. She notes that institutions such as the National Gallery with " "national' mandates...were instrumental in legitimating the cultural authority of this regional identity on a national scale." " Understanding the Gallery's history of promoting one central region is crucial to studying the inclusion of the Atlantic region in the biennial series.

Examples of the National Gallery of Canada's cultural hegemony are also elaborated upon in Museum Policy, Museum Practices and Cultural Change by Laurence Grant, which examines fifty years of Canadian museum policy using the National Gallery as a backdrop. Grant's historical analysis of the Miers-Markham report (published in 1932 as A Report on the Museums of Canada to the Carnegie Corporation of New York) and the influence of the Royal Commission on National Development in the Arts, Letters, and Sciences has been useful. This analysis highlights the centralizing tendencies in the Massey Report: tendencies which contradict the earlier Miers-Markham Report's recommendations to decentralize. Grant is informed by Italian philosopher Antonio Gramsci's writing on hegemony and anthropologist Victor Turner's investigation of the culturally transformative power of liminal moments in the institution. The relationship of the National Gallery of Canada to federal policies is further explored by Martha King in The National Gallery of Canada at Arm's Length from the Government of Canada: A Precarious Balancing Act. King's discussion of the significant role exhibitions played 
for the federal government by proving and promoting Canada's identity abroad are important for the assessing the biennial exhibitions' rise and fall and the place of international figures as jury members in the program. Other literature demonstrating the National Gallery's broader functions in Canada includes Anne Whitelaw's articles "Whiffs of Balsam, Pine, and Spruce: Art Museums and the Production of a Canadian Aesthetic" and "Statistical Imperatives: Representing the Nation in Exhibitions of Contemporary Art". ${ }^{8}$ While my study addresses a very specific and decidedly Canadian case study, it is informed by a broader body of international scholarly literature investigating the authority of the museum.

Seminal studies of the museum in society are included in Grasping the World: The Idea of the Museum, for example Tony Bennett's "The Exhibitionary Complex," Hans Haacke's “Museums: Managers of Consciousness," and Annie E. Coombes' "Museums and the Formation of National and Cultural Identities". Carol Duncan's influential "Art Museums and the Ritual of Citizenship" further illuminates museum representation and its roles in state and society. ${ }^{9}$ As a group, these authors approach museum representation from a new museological perspective. They address the narratives of inclusion and exclusion of social groups and examine museums' viewpoints. These authors note the influential role of the museum in informing and impacting national and social consciousness over a broad period.

In addition to texts investigating the cultural milieu in which the biennial series occurred, the National Gallery's history, and the role of museums in general, studies into other disciplines have been informative. Federal and regional political and economic histories and well as theories on nationalism have isolated factors at play in the creation 
of this exhibition series. These fields make valid contributions to this art historical study, as Newfoundland, Nova Scotia, Prince Edward Island, and New Brunswick's economic concerns and political affiliations have positioned Atlantic Canada as a specific geopolitical region understood in particular economic and political terms by the federal government. Federal policies of economic centralization shaped the economic and social history of the region, which in turn affected arts infrastructure.

To elucidate this politicized regional-federal history, several texts have been useful. Benedict Anderson's conceptualization of the nation as an "imagined community", expounded in Imagined Communities: Reflections on the Origin and Spread of Nationalism, grounds readers in the concept of nationalism, through examining what modes it has come into existence, what tools perpetuate this sense of communal consciousness, and how it is experienced. This text has been highly influential to studies of identity and representation across multiple disciplines. In "Regionalism and National Identity: Canada," Richard Preston extends Anderson's model to discuss regionalism, questioning how regionalism affects the ways in which Canadians think about their national identity and examines this issue by recounting several authors' perspectives on this topic. The contribution of Preston's article to the thesis research is the concept that regionalism, like nationalism, is arbitrary and malleable, made up of several factors that can be amalgamated to suit particular purposes and ignored when they are deemed unsuitable. Donald J. Savoie's "All Things Canadian are now Regional” discusses contemporary central-regional economic and political relations by looking at modes laid down in the 1960s, while James Bickerton's "Regionalism in Canada" draws on his 
background in historic and contemporary Ottawa - Nova Scotia relations to illustrate the history of federal-regional tensions. ${ }^{10}$

These scholars provide critical background for discerning the ideologies operating federally and regionally during the biennial years. In exploring Atlantic Canada's responsibility for articulating and disseminating a particular identity, the notion of the imagined community is important, as are writings on consciously anti-modernist approaches, particularly those utilized within Atlantic Canada. Several articles in Antimodernism and the Artistic Experience: Policing the Boundaries of Modernity, edited by Lynda Jessup, are pertinent to this study, particularly Ian McKay's "Handicrafts and the Logic of 'Commercial Antimodernism': the Nova Scotia Case." To understand Atlantic regional identity, McKay's The Quest of the Folk: Antimodernism and Cultural Selection in Twentieth Century Nova Scotia proved essential. Over four chapters, McKay documents the concept of the Folk and why it was highly inapplicable to the region, as well as the many individuals who manipulated and promoted a traditional, folk identity. ${ }^{11}$ McKay's book The Quest of the Folk: Antimodernism and Cultural Selection in Twentieth-Century Nova Scotia examines in depth the ways in which this identity was fashioned and promoted in one particular Atlantic province. ${ }^{12}$

One must delve further into Atlantic Canadian culture to understand the multifaceted identities comprising the Atlantic Provinces and the various artistic productions and communities found in the region preceding and during the biennial exhibition era. In art, regionalism can refer to an American movement or its Canadian equivalent. It is generally agreed that in the United States, the regionalist movement of the 1930s and 1940s was a reaction against an influx of European work into the 
American market and a lack of support for American artists. ${ }^{13}$ Canadian art historians have had a more difficult time delineating the exact meaning of that movement's Canadian counterpart. In Canada, the term "regionalism" has often been used to describe representational art representing an artist's immediate environment. For some art historians (such as R.H. Hubbard) this specificity clashed with a paradigm of universality as indicator of progress. ${ }^{14}$ This negative specter of regionalism clung to Atlantic art well into the 1950s and 1960s and affected its characterization as traditional and stagnant. Articles such as John Murchie's “Here \& There, Now and Agin (sic): Regions End Where Countries Begin" demonstrate the breadth of visual art created in this region during the biennial years. ${ }^{15}$

\section{Methodology}

Recent scholarship on regional and national identity, and museological representation, as discussed above, has provided the theoretical groundwork for my study. An examination of regional representation in the National Gallery's biennial series would not be possible if a precedent had not set by the aforementioned scholars. They have introduced institutional critique and highlighted the cultural necessity of critically examining exhibitions. My approach is in keeping with this development in museological scholarship and develops a critical historical narrative drawing upon my detailed, archival-based survey of the Atlantic region's representation in the biennial series. Rather than drawing on quantitative data, as Nathalie Limbos-Bomberg has, I have based my argument on institutional histories of the National Gallery and components of Atlantic Canadian arts infrastructure such as universities, art galleries, and arts organizations. Although quantitative data has a place in examining Atlantic 
representation in this thesis, this information does not point to the complex issues leading to that representation. The critical, qualitative method I used, however, illustrates the myriad factors involved in Atlantic Canadian art production and in representing a region in nation-wide survey exhibitions.

Materials at the core of this historical survey were the primary sources from the biennial exhibitions found at the National Gallery of Canada Library and Archives. Extensive biennial files contain administrative records for each exhibition, letters and other correspondence between committee members and gallery staff, telegrams, shipping records detailing the works submitted for selection, those rejected and those accepted, announcements and notes, and exhibition catalogues. These primary sources document the administrative and curatorial planning occurring throughout the series, providing valuable insights and clues into the project's rationale and symbolic structure.

Archival work was conducted in Atlantic Canada to determine and accurately discuss artistic production and arts infrastructure in the region during the biennial years. Files from the Maritime Art Association, the Nova Scotia Museum of Fine Arts, and the Nova Scotia Society of Artists include correspondence, meeting minutes, membership lists, newsletters, exhibition catalogues, and clippings pertaining to Atlantic Canadian artists and art societies. This material was indispensible in assembling a history of the region's visual arts infrastructure during the 1950s and 1960s.

\section{Chapter Breakdown}

The thesis' first chapter was designed to establish an understanding of the complex conditions in each Atlantic province before introducing the reader to the biennial series itself and the Atlantic region's participation in it. After the apparatus supporting the 
development and exhibition of Atlantic Canadian art in the biennial era is introduced, the region's representation in the seven exhibitions is examined over two chapters. The conclusion summarizes my findings and responses to the questions I posed during this project's initial phase.

Chapter One studies arts infrastructure in Atlantic Canada from the 1950s to late 1960s, coinciding with the biennial exhibition period. The history of art galleries, universities and schools offering fine arts education, and art societies is documented, as is the anti-modern impetus which swept the region. Key figures who advanced an antimodern view of Atlantic Canada, and their reasons for doing so, are discussed here as well.

Chapter Two explores the developments leading up to the Annual Exhibition of 1953 - the precursor to and first survey of the biennial series - and the first two biennial exhibitions of 1955 and 1957. Figures shaping the series, as well as the goals and obstacles facing it are discussed and Atlantic Canadian representation is assessed. Although initially well-represented in the series, by 1957 Atlantic Canadian artists contended with dwindling inclusion in the biennial exhibitions, difficulty securing locations to host the touring biennial exhibitions, increasingly negative characterization of the region's culture, and the escalating international path of National Gallery of Canada (under the direction of Alan Jarvis).

Chapter Three follows the National Gallery's attempt to reach out to Atlantic Canada after 1957 through travelling exhibitions, the creation of an Eastern liaison officer, and an exhibition devoted entirely to trends in contemporary Atlantic Canadian art. The region's continued representation in the biennial series is summarized to the 
series' demise in 1968 and factors leading to the series' end are discussed. In Chapters Two and Three, the views of organizers, artists, and the press are included to illuminate the strengths, weaknesses, and impressions of the series.

\section{Conclusion}

By consulting and synthesizing the primary and secondary research materials indicated above and organizing them in the fashion indicated by the preceding chapter summary, this thesis sheds light on how Canadians came to know Atlantic Canada and its art through the lens of the National Gallery of Canada's biennial exhibitions of Canadian art. Through its exploration of the infrastructure supporting art in Atlantic Canada, of the multifaceted ways in which the Atlantic region's art became characterized as traditional and anti-modern, and of how the National Gallery supported this view through the biennial exhibitions, this thesis explores Canadian art of this period from a unique perspective. 
Endnotes

${ }^{1}$ No Atlantic artists were included in Songs of Experience and no venues east of Montréal were scheduled to host the National Gallery's biennial exhibition in 1989. This biennial was slated to be the first in a series, but only one exhibition occurred. My first introduction to this under-representation came at an Atlantic Provinces Art Gallery Association (APAGA) annual general meeting in St. John's in 2005. Stephen Godfrey, "Exclusion from Biennial Prompts Protest," The Globe and Mail (6 December 1989). 2 Charles Comfort, "Foreword," $5^{\text {th }}$ Biennial Exhibition of Canadian Painting: 1963 (Organized and Circulated by the National Gallery (Ottawa: National Gallery of Canada, 1963), 1.

${ }^{3}$ Nathalie Limbos-Bomberg, The Ideal and the Pragmatic: The National Gallery of Canada's Biennial Exhibitions of Canadian Art, 1953-1968 (master's thesis, Carleton University, 2000). John Murchie, "Here \& There, Now and Agin (sic): Regions End Where Countries Begin," Art Libraries Journal 22, no. 4 (1997): 16-23.

${ }^{4}$ Limbos-Bomberg, 5-7.

${ }^{5}$ Douglas Ord, The National Gallery of Canada: Ideas, Art, Architecture (Montréal and Kingston: McGillQueens University Press, 2003).

${ }^{6}$ Paul Litt, The Muses, the Masses and the Massey Commission (Toronto: University of Toronto Press, 1992). Joyce Zemans, "Establishing the Canon: Nationhood, Identity and the National Gallery's First Reproduction Programme of Canadian Art," Journal of Canadian Art History 16, no. 2 (1995): 6-35. Maud F. Brown, Breaking Barriers: Eric Brown and the National Gallery (Ottawa: Society for Art Publications, 1964). Lynda Jessup, "Bushwackers in the Gallery: Antimodernism and the Group of Seven," in Antimodernism and the Artistic Experience, ed. Lynda Jessup (Toronto: University of Toronto, 2001), 130-152.

${ }^{7}$ Jessup, 136.

${ }^{8}$ Anne Whitelaw, "Whiffs of Balsam, Pine, and Spruce: Art Museums and the Production of a Canadian Aesthetic," in Beyond Wilderness, ed. John O'Brian and Peter White (Montréal and Kingston: McGillQueen's University Press, 2007), 175-180.

Anne Whitelaw, "Statistical Imperatives: Representing the Nation in Exhibitions of Contemporary Art," Topia: A Canadian Journal of Cultural Studies 1, no. 1 (Spring 1997): 22-41.

9 Tony Bennett, "The Exhibitionary Complex," in Grasping the World: The Idea of the Museum, ed. Donald Preziosi and Claire Farago (Hants: Ashgate Publishing Ltd., 2004), 413-441.

Hans Haacke, "Museums: Managers of Consciousness," in Grasping the World: The Idea of the Museum, ed. Donald Preziosi and Claire Farago (Hants: Ashgate Publishing Ltd., 2004), 400-412. Annie E. Coombes, "Museums and the Formation of National and Cultural Identities," Oxford Art Journal 11, no. 2 (1988): 57-68. Carol Duncan, "Art Museums and the Ritual of Citizenship," in Exhibiting Cultures: The Poetics and Politics of Museum Display, ed. Ivan Karp and Steven D. Lavine (Washington and London: Smithsonian Institution Press, 1991), 88-103.

${ }^{10}$ Benedict Anderson, Imagined Communities: Reflections on the Origin and Spread of Nationalism (London and New York: Verso, 2006). Richard Preston, "Regionalism and National Identity: Canada,' in Regionalism and National Identity: Multi-Disciplinary Essays on Canada, Australia and New Zealand, ed. Reginald John Berry and James Acheson (Christchurch, N.Z.: Association for Canadian Studies in Australia and New Zealand, 1985), 3-13. Donald J. Savoie, "All Things Canadian Are Now Regional," Journal of Canadian Studies, 35, no. 1 (Spring 2000): 203-217. James Bickerton, "Regionalism in Canada," in Canadian Politics, $3{ }^{\text {rd }}$ ed., ed. James Bickerton and Alain G.-Gagnon (Peterborough: Broadview Press, 1999), 209-238.

${ }^{11}$ See also Benedict Anderson, "Introduction to Part Two: Staging Antimodernism in the Age of High Capitalist Nationalism," in Antimodernism and the Artistic Experience: Policing the Boundaries of Modernity, ed. Lynda Jessup (Toronto: University of Toronto Press, Inc., 2001), 117-129.

Ian McKay, "Handicrafts and the Logic of 'Commercial Antimodernism': the Nova Scotia Case," in Antimodernism and the Artistic Experience: Policing the Boundaries of Modernity, ed. Lynda Jessup (Toronto: University of Toronto Press, Inc., 2001), 117-129. Ian MacKay, The Quest of the Folk: Antimodernism and Cultural Selection in Twentieth-Century Nova Scotia (Montréal and Kingston: Queen's University Press, 2006).

${ }^{12}$ Ian McKay, The Quest of the Folk: Antimodernism and Cultural Selection in Twentieth-Century Nova Scotia (Montréal and Kingston: Queen's University Press, 2006). 
${ }^{13}$ Virginia Nixon, "The Concept of 'Regionalism' in Canadian Art History," Journal of Canadian Art History 10, no. 1 (1987), 35.

${ }^{14}$ Ibid., 31-34.

${ }^{15}$ Murchie, 16-23. 


\section{Chapter 1}

\section{A Survey of the Visual Arts Infrastructure in Atlantic Canada from 1955 to 1968}

Cultural and economic conditions in Atlantic Canada during the 1950s and 1960s impacted artists' opportunities for development, exhibition, and recognition both within their provinces and region, and on national and international platforms. These obstacles limited Atlantic Canadian artists' prospects and played roles in characterizing the region's art (and people) in the mid-twentieth century as conservative, traditional, and out of touch with contemporary currents. This chapter documents the structures supporting Atlantic Canadian art education and exhibition and illuminates the complex conditions Biennial Exhibition organizers and artists confronted in New Brunswick, Nova Scotia, Prince Edward Island, and Newfoundland. This survey documents the region's substantial and often sophisticated but provincially-imbalanced fine arts infrastructure, including art galleries, art schools, and artists' associations. In presenting this history, I wish to underscore the diverse issues surrounding art production in the Atlantic region. This is fundamental in examining Atlantic Canadian inclusion in the National Gallery's biennial exhibitions, as the series' literature does not readily communicate these conditions of production.

\section{Obstacles and Issues Facing Atlantic Canadian Artists}

While the region was home to many professional artists and numerous arts societies, which fostered artistic talent and had varied political goals, imbalances existed in some provinces' abilities to showcase and develop these individuals as well as encourage and support the public's understanding and appreciation of visual art. A lack of public 
galleries and forward-looking art educators existed in Nova Scotia, Prince Edward Island and Newfoundland. New Brunswick was home to the majority of fine art galleries in the region during the biennial exhibition period with four such institutions. Among the region's galleries, a limited number met National Gallery exhibition standards for fire protection and professional administration, ${ }^{1}$ thereby prohibiting many provinces including Nova Scotia, Prince Edward Island, and Newfoundland from hosting the Biennial exhibitions from which they were often (or in the case of Prince Edward Island, always) excluded.

Frustratingly for both the region and the National Gallery, which attempted to reach out to Canada's more peripheral areas though its extension services, ${ }^{2}$ the lack of reliable exhibition space in some Atlantic provinces prevented many areas from accessing any travelling exhibitions organized and circulated by the National Gallery. In some instances, reproductions were the best "art" some provinces could expect to receive. ${ }^{3}$ Several artists who had exhibited abroad had not shown work in their home cities for this very reason. ${ }^{4}$ Regional exhibition networks and makeshift galleries (set up exclusively to cater to tourists in some cases) addressed this problem during these decades but were only stop-gaps until more permanent venues and dependable arrangements could be made.

Isolation and distance from cultural hubs were also problems artists in the region faced. ${ }^{5}$ These factors affected not only exhibition opportunities, but access to art education as well as patronage. The region's universities were crucial sites for fine art education and often provided the only exhibition space in a given town or city. They increasingly married liberal arts philosophies with facilities and programs for the 
creation, exhibition, and teaching of visual art and its history. This relationship was believed to be worth cultivating in order to develop critically inquisitive and knowledgeable citizens; by studying art, individuals developed the intellectual discipline necessary to a successful liberal education. ${ }^{6}$

Accessing the services and benefitting from the opportunities universities offered could be problematic, though, as these facilities were located in the southern New Brunswick city centres of Fredericton, Moncton, and Sackville, as well as Halifax and St. John's. Rural dwellers, who during this period accounted for the majority of the region's citizens, found it difficult to travel to these hubs with any regularity. ${ }^{7}$ Community art classes and summer workshops filled gaps in local instruction, but limited contact with actively evolving artists and avant-garde practices impacted the results of these programs.

Saint John artist Jack Humphrey devoted an article in Canadian Art to the problems facing Atlantic Canadian artists in 1955. He highlighted isolation as one of the greatest problems plaguing artists in the region, noting that even the region's metropolitan areas were distant from the nearest Canadian art centres: Montreal and Toronto. This distance, Humphrey believed, illuminated Atlantic artists' lack of a "mental atmosphere" of creative camaraderie and the sustained visual and mental stimulus necessary for creative production.

In practical terms, Humphrey believed that limited financial support for the region's artists was due to a lack of public art education, a quickly saturated local art market, and difficulties selling work in large Canadian art centres. ${ }^{8}$ The level of private patronage in art hubs such as Montreal, Toronto, and Vancouver was much greater than 
in Atlantic Canadian city centres, where the economic downturn which swept the region in the 1920 s continued into the 1960 s. $^{9}$

The poor economic outlook in Atlantic Canada was brightened by other regions' fortunes. Prosperity in other parts of the country encouraged tourists to flock to Atlantic Canada for recreation. The tourism industry was a major force driving the economy in New Brunswick, Nova Scotia, and Newfoundland as early as the turn of the twentieth century. An integral facet of the tourism industry was cultivating a primitive, antimodern image of the region, a place where "weary brain workers" could escape city pressures and rejuvenate. ${ }^{10}$ Tourism was important to Prince Edward Island as well, but the province did not begin developing a targeted plan for improving this industry until the mid 1960s. ${ }^{11}$ Since 1870 , tourism had figured as a significant part of Newfoundland's economy. Twentieth-century economic difficulties made profits from tourism even more imperative in the province. ${ }^{12}$

Promoting traditional handcrafts, such as rug hooking ("the art of the people"), ${ }^{13}$ was paramount to providing an authentic tourist experience in Nova Scotia and New Brunswick. In 1942 the Nova Scotia government hired Mary Black, an occupational therapist born in Nova Scotia who had worked in the United States, to head the province's Handcrafts Division. ${ }^{14}$ Black believed that to satiate tourists' desire for articles which were "evocative" of the province, goods had to reflect the Maritime environment using a variety of designs which appealed to both the "discriminating purchaser and the souvenir hunter." ${ }^{\prime 5}$ In 1946, the New Brunswick government also realized the link between promoting handcrafts and improving the tourist experience. The provincial government established a Handicrafts Branch under the Department of 
Industry and Development to train more people to make saleable crafts or "authentic souvenirs". ${ }^{16}$ Hand-made crafts embodied the quaintness of the anti-modern while providing commodities for tourists. However, by 1930 the design and production of hooked rugs in Nova Scotia's famous hooking village, Cheticamp, was guided not by the weavers themselves but by an American occupational therapist, Lilian Burke, who altered traditional colours and patterns and dictated where and how rugs were sold. In New Brunswick, patterns were stamped onto burlap so hooked rugs could be "sold by the thousands". ${ }^{17}$ The production of these goods in fact occurred under very modern conditions.

Dartmouth-born folklorist Helen Creighton was instrumental in shaping a folk view of the region. ${ }^{18}$ Creighton was born into a well-off family which was prominent in Halifax's business community. This community maintained a Victorian conception of the Maritimes as a place integrated into the modern world, a region which was fertile, garden-like, and contained. In her work, though, she devised and promoted an opposing view of the region, characterizing it as primitive, rugged, and barren. ${ }^{19}$

Her work as a folklorist began in 1928 when she travelled to the outskirts of Dartmouth and Lunenberg, gathering fishermen's pirate and working songs, ballads and tales. She did so because she feared these people at the heart of the "authentic" folk Maritime experience were disappearing. She selectively met with people in Nova Scotia and New Brunswick who were not - supposedly - modern and not working in modern industries, but instead lived in rural communities, in particular those who worked on the sea. $^{20}$ 
Through articles, books, radio and television broadcasts, Creighton painted these individuals and communities in which they lived with the brush of "The Folk," defining them at their essence as decent, deferent, humble, modest, loyal and homogenized, and locating them at the core of every Nova Scotian's cultural identity. ${ }^{21}$ After working for twenty years (from 1947 to 1967) at the National Museum of Canada in Ottawa and disseminating her view of the region throughout the country, Creighton received the Order of Canada in 1976 for "valuable service to the nation". 22

Despite these obstacles (and the occasional, inevitable internal squabbles), ${ }^{23}$ community and regional art societies, along with artists and arts administrators, persevered and contemporary visual arts began thriving in the region in the 1970s and 1980s. Throughout the biennial exhibition years, the provinces actively supported each other and encouraged the continued development of the arts in Atlantic Canada with exhibitions and regional tours as well as through annual Maritime Art Association meetings where artists and arts administrators would unite to share information and overcome mutual problems. ${ }^{24}$ Avant-garde practices, such as conceptual art which was new to the Atlantic region, were introduced during the final year of the Biennial Exhibition program. Throughout the span of the Biennial Exhibition program, the Atlantic region was associated with representational painting. After the appointment of Garry Neill Kennedy as president of the Nova Scotia College of Art in 1967, conceptual art began drawing international attention to Halifax, in particular. ${ }^{25}$

\section{New Brunswick}

The Beaverbrook Art Gallery, the University of New Brunswick Art Centre, the New Brunswick Museum, the Université de Moncton, and the Mount Allison University Art 
Gallery served New Brunswickers in Fredericton, Saint John, Moncton, and Sackville. The Beaverbrook Art Gallery opened on September 16, 1959, thanks to the generosity of philanthropist Lord Beaverbrook (William Maxwell Aitken), who donated the gallery and its contents with the goal of guiding and encouraging new talents and giving people, especially youth, the opportunity to interact regularly with visual art. ${ }^{26}$ After opening, the Beaverbrook Art Gallery was a preferred Atlantic Canadian venue for hosting travelling exhibitions from the National Gallery of Canada, including the Biennial Exhibitions intermittently (the third in 1959 and the sixth in 1965). The facility boasted a separate Travelling Exhibition Room for such purposes. ${ }^{27}$ Its curators often requested the Biennial Exhibitions and secured them for their schedule well in advance. It became the provincial art gallery in 1983.

The New Brunswick Museum, the official provincial museum since 1929, was originally founded in 1842 as Gesner's Museum of Natural History. Its haphazard development parallels the foundation and formation of other museums in the region. Geologist and Cornwallis, Nova Scotia native Dr. Abraham Gesner (1797-1864) opened it to showcase his collection of natural history specimens and "curiosities" - from both New Brunswick and the Atlantic region as well as from abroad ${ }^{28}$ - after the provincial government failed to fund his proposed museum. His inability to secure revenue led to the museum's contents being turned over to the Saint John Mechanics' Institute in 1846. The Institute was developed by the New Brunswick Philosophical Society but later dissolved and its collections went to the Natural History Society of New Brunswick. ${ }^{29}$ This society acquired new specimens for its growing collection and moved the museum's contents several times, eventually settling in a new location in 1934, the province's one 
hundred and fiftieth anniversary. The museum later found new housing for its exhibition centre in uptown Saint John in $1996 .^{30}$

Art works have been acquired and displayed throughout the Museum's history, with a particular focus on New Brunswick artists, exemplified in its Know Your Own Artists series beginning in 1949, featuring ten artists in ten exhibitions. Miller Brittain, Ted Campbell, Julia Crawford, Violet Gillett, Jack Humphrey, Lucy Jarvis, Fred Ross, Alex Colville, and Elizabeth Sutherland each had a solo exhibition including a catalogue. $^{31}$ The New Brunswick Museum also hosted the first and fourth biennial exhibitions in 1955 and 1961.

Three major universities in the province had both fine arts faculties as well as exhibition space. Mount Allison University's School of Fine and Applied Arts (the oldest department of its kind in the country, established in 1869) served students and faculty in this department first and foremost, but also extended its role into the wider university community, and the general community, and also served Nova Scotia citizens due to its relative closeness to the provincial border.

In 1867, Saint John shipbuilder, merchant, and philanthropist John Owens bequeathed a donation to the city for religious and artistic youth education. These funds eventually allowed the Owens Art Institution to develop in Saint John in the early 1880s. ${ }^{32}$ The Institution's first principal and art instructor, John Hammond, was a prominent painter from Montreal and was responsible for acquiring artworks for the Institution's permanent collection during his international travels.

By 1893, the Owens Art Institution had grown short of funds despite a handsome enrolment, just as the Mount Allison Board of Governors believed the creation of an "Art 
Hall" in the Ladies' College was a worthy undertaking. Students at Mount Allison's Ladies' College had already studied painting and drawing with John Warren Gray, appointed to the Fine Arts Faculty in 1869. He remained at the school until 1873, when his salary became higher than the College's profits. Although the College began a fouryear diploma course in art in 1887 instructing students in drawing, watercolour and oil painting, design, and composition as well as "china modelling" and decorative work, ${ }^{33}$ there was no professor of fine arts until, through a circuitous and serendipitous route, Mount Allison University absorbed the Owens Art Institution.

After quick negotiations between board members, the University began constructing a new art gallery and John Hammond brought the Owens collection and his skills as a painter to Sackville. Hammond taught at the Ladies' College as its professor of fine arts from the Institution's move in 1893 until his retirement in 1916. He brought considerable distinction to the school, due to the admirable collection he had amassed and his prestige, witnessed by his exhibition history (at the Paris Salon, London's Royal Academy, and National Academy of Design in New York City), his association with important European artists such as J.M. Whistler and Jean-François Millet, and patrons such as Sir William Van Horne. ${ }^{34}$

Hammond was eventually replaced by the English painter Stanley Royle in 1936. During Royle's tenure, the Ladies' College was absorbed into the university, which began granting Bachelor of Fine Arts degrees. ${ }^{35}$ In 1946, Lawren P. Harris took over as Department Director and Owens Art Gallery administrator, positions he held until 1975 and 1973, respectively. ${ }^{36}$ In addition to his teaching duties, Harris undertook an 
expansive review and augmented the academic requirements and scope of the bachelor of fine arts program.

As a result of Harris' tour of central Canadian and American art schools in the summer of 1949 , the University began offering courses in graphic arts and sculpture and instituted programs to train commercial artists, industrial designers, and arts educators. A two-year diploma in handicrafts was added to the University's offerings, aimed at the budding craftsperson or art teacher. ${ }^{37}$ The efforts of newly-hired assistant professors and former students Alex Colville and Edward B. (Ted) Pulford, did much to advance the work of the expanded Fine Arts Department and produced many notable graduates, some of whom were Atlantic Canadians as well, highlighting the University's important place as a training ground for artists from the region. ${ }^{38}$ During the Biennial Exhibition era, the artists most readily associated with Mount Allison University painted in a representational manner. Graduates such as Hugh MacKenzie, Mary and Christopher Pratt, Bruce St. Clair, Ken Tolmie, Hugh MacKenzie, D.P. Brown and Tom Forrestall painted landscapes, figures, and domestic subjects exclusively. ${ }^{39}$ Mary and Christopher Pratt in particular are celebrated for their painstakingly techniques, and markedly different results, which record interior domestic scenes and portraits of the world and people around them. ${ }^{40}$

The University of New Brunswick Art Centre in Fredericton was founded by Pegi Nicol MacLeod, Lucy Jarvis, and Margaret MacKenzie (wife of the University's president, Norman MacKenzie) in 1941, making it the oldest university art centre in Atlantic Canada and the first visual arts institution in the city. Nicol MacLeod's husband was born in the city and she spent summers in Fredericton organizing exhibitions, 
teaching art classes at the University in the summer art program she developed, and working with local artists and artisans. ${ }^{41}$ Nova Scotian and fellow painter Lucy Jarvis served as the Centre's first director. Under Jarvis' direction, the Art Centre held art classes, and hosted meetings and temporary exhibitions by local and Canadian artists as well as travelling exhibitions and concerts. Jarvis is remembered as an eclectic woman who imbued the Art Centre with a personal touch by playing records on a student-built high fidelity stereo and serving tea. She took a genuine interest in the centre's patrons and made the space part art centre and part student drop-in centre. ${ }^{42}$

The story of the Art Centre's founding demonstrates the tenacity of visual arts supporters in the region. Jarvis, quoted in A Pictorial History of the University of New Brunswick, recalled MacKenzie's curiosity about the "funny little building" on campus. This curiosity led MacLeod, Jarvis and MacKenzie to clamoring over bushes and cross the threshold of the dilapidated Brydone Jack Observatory. This small, neglected observatory - Canada's first, erected in 1851 - became the UNB Art Centre after a lot of repair, and a national historic site in $1955 .{ }^{43}$ The Art Centre was moved to Memorial Hall, a more central location on campus to better serve its primary audiences (students and faculty) in $1960 .{ }^{44}$

Jarvis retired in 1960 to paint full-time and was replaced in 1962 by Bruno Bobak. Bobak was the second participant in the University of New Brunswick's progressive artist-in-residence program, following Goodridge Roberts, who had been appointed in 1959. The University attempted to distinguish itself as an ardent supporter of arts education and champion of well-rounded and continuing intellectual development by claiming to be the first university in the country to launch this type of program. ${ }^{45}$ In 
fact, the University of Saskatchewan had been the first to do so nearly forty years earlier with the appointment of English artist Augustus Kenderdine, but the University of New Brunswick's claim highlighted the increasingly important role the arts played in drawing individuals to institutions. ${ }^{46}$ Bobak remained the Art Centre's director until 1986 and attracted an impressive group of artists and instructors to the University during his tenure. These included Alfred Pinsky, Fritz Brandtner, Goodridge Roberts, Donald Reichert, and his wife Molly Lamb Bobak. ${ }^{47}$

A third New Brunswick university, the Universite de Moncton, played an important role in fostering an Acadian renaissance in the province and the region, and in establishing a strategic place in visual art education and development in the province. Amalgamating three francophone colleges into its administrative structure meant that this institution welcomed students from smaller centres served by these original schools (Memramcook, Edmundston, and Bathurst) and exposed rural Acadian students to a new world. The school launched a visual arts department when it opened in 1963 and created an Arts Centre in 1965 due in large part to the efforts of Claude Roussel, a sculptor born in Edmunston. Roussel was a former art teacher in the francophone schools in northern New Brunswick and later became a founding professor and director of the Université de Moncton's visual arts department after working as assistant curator at the Beaverbrook Art Gallery from 1959 to 1961. Roussel worked tirelessly as an advocate, professor, and curator to advance the careers of Acadian artists, establishing the Université's art centre and showcasing Acadian visual art through such exhibitions as Sélection '65 and Sélection ' $67 .^{48}$ 
In addition to universities, artists' societies and art associations supported local emerging and established artists, and the cultural work that museums and galleries performed in the Atlantic provinces. New Brunswick was home to the Edmunston Art Club, the Fredericton Art Club, the Fredericton Society of Artists, the Sackville Art Association, the St. Andrews Art and Study Club, the Music, Art and Drama Society of St. Andrews, the St. Croix Art Association, the Moncton Society of Art, the Saint John Art Club, and the Woodstock Art Club. Several schools in the province also counted themselves among the Maritime Art Association's member groups, indicating that the study and creation of art was vital not only to universities but to vocational school students and teachers alike. ${ }^{49}$

The Saint John Vocational School, for example, actively supported travelling Maritime Art Association exhibitions and art education initiatives through its Department of Fine and Applied Art and worked in cooperation with provincial and regional art clubs and associations to bring artwork and lectures to the city, although the school was under no formal obligation to do so. ${ }^{50}$ The determination and partnership of culturally-minded groups such as these worked in concert (unofficially) with groups and museums to bring greater awareness of the visual arts to the public.

\section{Nova Scotia}

Nova Scotia was home to several art associations which were integral to visual arts in the province, including the Louisbourg Chapter of the Imperial Order of the Daughters of the Empire on Cape Breton Island, the Port Hawkesbury Art Club, the New Glasgow Arts and Letters Club, the Amherst Art Association, the Nova Scotia Museum of Fine Arts, the Halifax Picture Loan Society, the Nova Scotia Society of Artists, the Atlantic 
Amateur Painters, the South Shore Art Association, and the Yarmouth Art Association. ${ }^{51}$ These groups organized sketching and painting outings for their members, displayed their works in makeshift locations ranging from church halls to schools and fly-by-night art centres, ${ }^{52}$ and provided a dose of camaraderie for like-minded individuals. Larger groups such as the Nova Scotia Society of Artists linked members across the province through information bulletins and members-only annual spring and autumn exhibitions. ${ }^{53}$ Members located outside Halifax gathered to overcome the isolation of working in smaller centres and encourage healthy competition with each other. ${ }^{54}$

The Nova Scotia Museum of Fine Arts was an active organization founded in 1908 with the express purpose of encouraging the visual arts in Nova Scotia and fostering the creation of a provincial gallery in Halifax. ${ }^{55}$ Its executive and members met regularly in each other's homes to socialize, paint, learn about art through member lectures and guest speakers, and discuss ways in which to lobby government, business leaders, and philanthropists, such as Lady Dunn (Marcia Christoforides), to build a proper museum. The English-born Dunn was well known in Halifax as Dalhousie University's benefactor after the death of her husband, the financier Sir James Hamet Dunn. Sir James was born in New Brunswick and graduated in 1898 from Dalhousie University's School of Law. The young Lady Dunn was eager to memorialize her husband after his 1956 death, and rumours soon abounded in Halifax that this would materialize as a cultural centre. Such a memorial would come, but in the form of a stateof-the-art science building for Dalhousie University. ${ }^{56}$

The Nova Scotia Museum of Fine Arts, the Nova Scotia Society of Artists and the Halifax Picture Loan Society banded together in search of suitable venues and 
lobbied the provincial government for assistance. A letter to the deputy minister of Education, signed by the above groups, summarizes the frustration within the province, the battle its artists faced for exhibition venues and subsequent recognition, and the feeling that Halifax in particular and Nova Scotia in general were "slipping behind other cities and provinces": ${ }^{57}$

For many years the several Art Societies in Nova Scotia have been struggling to find the physical facilities essential to the development of their work...So far their efforts have been unsuccessful... with the result that the cause of art in the province has greatly suffered. There is little doubt that the general impression in Canada that Nova Scotia is very backward in the field of creative art is largely due to this lack of facilities. There is in fact a great deal of creative work being done in the plastic arts in Nova Scotia but it will probably not be recognized elsewhere until some means can be found to exhibit it more freely. ${ }^{58}$

Until 1988, when the Art Gallery of Nova Scotia moved into a space in the Dominion Building, temporary exhibitions of its collection as well as work by children and local artists were held at various locations, most notably the Halifax Memorial Library in the 1950s and 1960s. Opened in 1951, the Library was lauded as the first fireproof exhibition space in Halifax and boasted an "art room with twelve movable screens for hanging pictures. ${ }^{.59}$ Its budget enabled approximately six exhibitions to be hosted annually, some of which were circulated by the National Gallery of Canada. ${ }^{60}$

To some members of the Maritime Art Association, Halifax was in "an enviable position" and was considered "a metropolis, where one has greater opportunities for displaying art such as [the] Memorial Library." ${ }^{\circ 1}$ This idea that a room with moveable panels constituted an enviable site for exhibition demonstrates how inadequate visual arts venues were in some Atlantic communities. Commercial galleries, particularly the longstanding Zwicker's Gallery, supported the cultural framework of the city, but were not venues driven by educational mandates or public tax dollars. 
The Dalhousie University Art Gallery and the Nova Scotia College of Art (NSCA) were important centres for critical, contemporary, professional exhibitions in the province. The Dalhousie Art Gallery opened in October 1953 with a speech by British art critic Eric Newton in a newly constructed arts and administration building. The art gallery consisted of a small space with one hundred running feet of wall space where the permanent collection and local artists' exhibitions were hung. The Dalhousie Art Gallery hosted gallery talks and lectures and began for the University an internal loans program consisting of framed reproductions. ${ }^{62}$ Notably, the gallery made great efforts to support local artists within its programming, which included Know Your Artists, a series of exhibitions begun in 1955, designed in concert with the Maritime Art Association and modeled on the New Brunswick Museum's series Know Your Own Artists, to promote artists from Nova Scotia through exhibitions and detailed exhibition catalogues. ${ }^{63}$ The Dalhousie Art Gallery moved into the Dalhousie Arts Centre, its current and more spacious home, in $1971 .^{64}$

The Nova Scotia College of Art (formerly the Victoria School of Art and Design and now the Nova Scotia College of Art and Design University) was, in addition to Mount Allison University, a key site for artistic training for Maritime students. The Victoria School was established in Halifax in 1887 by educator and author Anna Leonowens to instruct students in the fine and industrial arts, bring the arts $-\mathrm{a}$ force of spiritual good - to Victorian Halifax, and link the city with other art centres in North America. ${ }^{65}$

Under the direction of English-born artist and member of Group of Seven Arthur Lismer (principal from 1916 to 1919 and lone faculty member for some time), the school 
charted a more focused and energized course than it had been on since its founding. NSCA added design courses, pronounced its inclusiveness in a series of advertising pamphlets aimed at parents, teachers, employers, and youth, and boosted enrolment thanks to Lismer's grassroots recruitment campaign within community schools. Lismer organized courses in art appreciation to stimulate and broaden the public's awareness of the arts and encouraged public school teachers to register in the school's art education program. While the Saturday morning children's art classes he taught were not a first for the school, his inclusive philosophy was. ${ }^{66}$ Lismer significantly bolstered the Halifax public's relationship with art and fostered art appreciation in a new generation of Haligonians.

Donald C. MacKay, a Fredericton native and 1928 graduate of the Nova Scotia College of Art, became principal in 1945 after serving as a naval war artist. MacKay was an educated, well-travelled, and regularly exhibited artist and art historian who was once a student of Lismer's at the University of Toronto and shared his views on democratizing art education. During MacKay's tenure, the College saw enrollment soar to a historical peak as returning veterans flooded Halifax. This influx demanded more space for the College's existing programs and it was believed that meeting this obligation could also serve the needs of the Halifax arts community by incorporating an art gallery into a new structure.

In 1954 MacKay negotiated unsuccessfully with the provincial government and the Halifax City Council to erect a building suitable for these purposes: one which would harmoniously satisfy the needs of the school, the Nova Scotia Society of Artists, and the Nova Scotia Museum of Fine Arts. Instead, three years later, the College moved into a 
former church hall near Dalhousie University, purchased with a Halifax City Council grant and provincial funding. After occupying multiple sites in the city, the three-story Coburg Road campus seemed to meet the needs of the College and the broader community and was described by Halifax Mayor Leonard Kitz as "the cultural heart of the province." ${ }^{67}$

The campus, with its nine classrooms, offices, library and lecture hall, was considerably enhanced by the presence of a space devoted entirely to exhibitions. Here the College could professionally mount and host exhibitions of its students' work and exhibitions loaned from various Canadian art societies, such as the Canadian Society of Painters in Water Colour, and those organized by the Nova Scotia Society of Artists, the Nova Scotia Museum of Fine Arts, and the Maritime Art Association. ${ }^{68}$ This extra space for exhibitions was a boon to the city's multiple groups, who did not have sufficient space for their many projects. This space better supported the juried Annual Exhibitions held by the Nova Scotia Society of Artists since 1926 and which the NSCA customarily hosted ${ }^{69}$ MacKay actively liaised with the Nova Scotia Society of Artists and the Nova Scotia Museum of Fine Arts to lobby for a provincial art gallery or, at the very least, a public space devoted to art exhibition and collection, as, by the mid-1960s, the new campus was quickly becoming cramped. ${ }^{70}$

In 1962 the Nova Scotia College of Art became affiliated with nearby Dalhousie University and offered its first fine art degree (which proved unsuccessful graduating no students from the program). In the same year, the College began offering a four year commercial art diploma, with government support for vocational training, and an applied art diploma program consisting of craft-based practices. An art education diploma was 
also offered, which, attractively, allowed students to qualify for the provincial teachers' certificate and increased the number of specialized art instructors in Nova Scotia. ${ }^{71}$

Garry Neill Kennedy shook up the school and the city and, arguably, the entire Atlantic region, upon his arrival from Wisconsin in 1967. Although MacKay stayed on in an honorary position at the College until 1970, the young Kennedy was hired to fill the newly-coined position of president, part of an administrative transformation the board of governors made in response to the challenges of the College's growing student body and its expanding complexity as an institution in need of direction. ${ }^{72}$ Until Kennedy arrived and recruited a cohort of contemporary conceptual artists to teach at the school, the NSCA had encouraged traditional artmaking in Nova Scotia. As late as the mid-1960s, NSCA students began their day with prayers before learning to naturalistically represent still lifes, landscapes, and marine scenes in oil paint, watercolour, and print. Life drawing from the nude had only recently been introduced ${ }^{73}$ and art history courses did not cover art production after the early twentieth century. Faculty and administration looked no further than Ontario for inspiration in formulating curricula and class structure. ${ }^{74}$

Artists from around the world took notice of the small school during the late 1960s and into the 1970s when under Kennedy's guidance the Nova Scotia College of Art and Design (the name was changed yet again in 1969) became an international locus for conceptual art. Instead of turning to Ontario, Quebec, or Europe for artistic models (late-nineteenth and early-twentieth century models specifically), students were inspired by and oriented towards New York and the United States' minimalist, conceptual, and performance artists. ${ }^{75}$ However, these transformative, avant-garde practices did not take root in the city or the region until after the Biennial Exhibition program ended. 
Stewards of the Halifax art community and, in particular, faculty members whose contracts were not renewed in 1968, were enraged by their replacement by American instructors (such as Gerald Ferguson, David Askevold, and John Pearson) practising what they felt to be ludicrous art forms. Their work was often devoid of representational imagery; these creators were not satisfied with realistic depictions of the Maritime landscape, essential subject matter in much of the region at the time. ${ }^{76}$ Kennedy saw that by 1968 in Halifax (and perhaps the entire province and region) "The notion of abstract art was still a controversial topic greeted with equal measures of ignorance and skepticism." 77 Some students protested these actions by taking to the streets while others were optimistic about the changes occurring. ${ }^{78}$

Although the Halifax public was not ignorant of modern art, thanks to various lectures, debates, and exhibitions on the topic, avant-garde art - especially non-traditional forms of expression - was something they were entirely unaccustomed to. ${ }^{79}$ Indeed, many in the city were left reeling from their encounters with abstract and expressive offerings by a handful of local artists, such as Ruth Wainwright, LeRoy Zwicker and Robert Annand. ${ }^{80}$ When Kennedy arrived, he noted that the College's programs "were tied to the past, emphasizing traditional form and content continuous with traditional Nova Scotia arts and crafts styles."

Provoked to radically alter the staid but promising environment of the College, Kennedy felt a "fresh start" could be made which would positively impact the school and even the province. ${ }^{82}$ The sweeping changes Kennedy implemented at the institution alienated many local people who had associated the Nova Scotia College of Art with representative art (underlining the conservative tastes encountered in the region) but 
brought prestige, important contemporary thinkers, and international attention to Halifax. ${ }^{83}$

\section{Prince Edward Island}

Until 1964, two active art groups on the Island made do with the spaces they could find to exhibit members' work and travelling exhibitions. Although the National Gallery of Canada offered to send exhibitions, including the Biennial Exhibitions, to the province, the Prince Edward Island Art Society failed in its efforts to secure suitable space for them. ${ }^{84}$ A major coup for the Prince Edward Island Art Association came in 1958 when the City of Charlottetown allowed the Society's members to use one of its heated rooms for exhibitions, free of charge, on the condition that some of its members paint backdrops for the city's centennial celebrations. ${ }^{85}$ Although this meant Island artists could not be exposed to the caliber of exhibitions they wanted, they still had a space to exhibit their own work.

Like Nova Scotia artists and art institutions, who were associated with conventional subject matter and styles of painting and who lobbied for permanent spaces to display and create a dialogue about art, Prince Edward Island was linked with the past and searched for adequate exhibition space. But this small Atlantic province had played an important role in the nation's birth and its capital was in no risk of being ignored as Canada's centennial celebrations approached. In 1964, the Confederation Centre was constructed in Charlottetown as a national memorial to the fathers of confederation who had gathered in the city 1864 . Funded by the federal and all the provincial governments, the Centre, housed within a stylish, modern façade a memorial hall, theatre, library, lecture theatre, restaurant, meeting rooms and an art gallery and museum. ${ }^{86}$ 
The Confederation Centre Art Gallery opened its doors in June 1964 in a ceremony presided over by Vincent Massey, former Governor-General of Canada, former chairman of the Royal Commission on National Development in the Arts, Letters, and Sciences (commonly known as the Massey Commission), and former chairman of the National Gallery of Canada's board of trustees, among other distinguished roles. ${ }^{87}$ The exhibition presented was A Century of Colonial Painting, assembled by the National Gallery for the occasion. Four murals Jack Shadbolt, John Fox, Jean-Paul Lemieux, and Ronald Bloore were commissioned and donated by the Molson family, the Montreal Star, Mr. and Mrs. S. Bronfman, and Bloore himself for the grand opening. These were placed in the centre's main concourse. ${ }^{88}$

After moving into the Fathers of Confederation Memorial Building, the gallery began assembling a collection through purchase and donation. By 1969 , this collection consisted of approximately two hundred works, including paintings, watercolours, drawings, graphic work and sculptures, by historic and contemporary Canadian artists from all regions, from Cornelius Krieghoff to Joyce Wieland. In 1965 the contents of the Robert Harris Trust were donated to the Gallery and contained over fifteen hundred works by the Island-born artist. ${ }^{89}$ The gallery also commissioned Canadian artists to create a series of twelve banners for Memorial Hall. Participating artists, including Takao Tanabe, Kenneth Lochhead, Jack Bush, Peter Bell, and Roy Kiyooka, were flown to Charlottetown for the June 1968 unveiling. The gallery also hosted national and international travelling exhibitions, by artists such as Henry Moore. ${ }^{90}$ Despite the province's previous lack of first-hand exposure to contemporary Canadian art, the Confederation Centre Art Gallery immersed itself in the currents of Canadian and 
international art and brought Prince Edward Island into contact with the contemporary art world.

The Centre's first curator, Moncrieff Williamson, who held the position from 1964 to 1982 , was heavily involved with Canadian craft in the 1960 s and ambitiously envisioned a national fine craft museum in Charlottetown. Although the Scottish-born Williamson came to Prince Edward Island through Western Canada (Calgary and Victoria), London, and the United States, ${ }^{91}$ he was a strong proponent of the Atlantic region's crafts and craftspeople. His knowledge and acceptance of "conceptual craft objects" as legitimate forms of visual art opened the door for craftspeople in the region to have their work viewed not as traditional, regional, and anti-modern, but as contemporary, Canadian, and sophisticated. ${ }^{92}$ He believed the 1960 s brought technological advances which would help artists in the region shed the restrictive identity shrouding their craft and expand beyond the isolating borders which had plagued artists and kept their work bound with a reductive and marginalized regionalism. ${ }^{93}$

Williamson did not consider "regional" a derogatory term, yet he did not believe (as other craft advocates in the region, such as Mary Black, had done) that craftspeople should romanticize their geographic ties. Although well aware of the term's tarnished use Canadian art history, Williamson believed that regions' cultural richness was important and could be a source of national pride. ${ }^{94}$ Unfortunately, in spite of curating important craft exhibitions such as Canadian Fine Crafts for Expo 67's Canadian pavilion, Canada Crafts for the Canadian Guild of Crafts in 1967, as well as Canadian Fine Crafts (with friend Norah McCullough) at the National Gallery of Canada in 1966, and building a collection of sixty-nine craft objects for the Confederation Centre Art Gallery's 
permanent collection, Williamson's national craft museum never materialized. The objects he acquired remained at the Confederation Centre Art Gallery as uneasy artifacts from a time when boundaries between art and craft, concept and tradition, national and local were blurring. ${ }^{95}$

\section{Newfoundland}

Canada's newest province, although culturally vibrant, had the least amount of cultural infrastructure in the Atlantic region throughout the 1950s and 1960s. Newfoundland artists were especially isolated in comparison to their regional peers, both geographically and psychologically. ${ }^{96}$ Unlike Saint John, where Ted Campbell's studio in the 1940s became a refuge for artists, musicians, poets, and authors working in the then-isolated city, the few artists working in Newfoundland were spread out and regular moral support was hard to come by. ${ }^{97}$ Memorial University in St. John's, like other universities in the region, offered a hub for visual art education and exhibition and became a beacon for artists across the province.

Although it opened its doors in 1925, Memorial University did not offer a fine arts diploma or degree program as many of its regional counterparts did. However, even in its early years the school employed visiting lecturers to teach art appreciation courses and train artistically minded teachers in the public school system. Eventually, a Specialist in Art was hired to teach non-credit courses through the University's Extension Service.

The art classes at Memorial University filled the void left by the Newfoundland Academy of the Arts, founded by Reginald and Helen Parsons Shepherd, which closed in 1961. Curator Patricia Grattan attributes the Shepherds' 1949 return to Newfoundland 
from the Ontario College of Art with the birth of professional artmaking in the province. ${ }^{98}$ Upon returning to St. John's, the couple opened their own arts academy modeled on the Ontario College of Art and an academy operated by two former classmates in Toronto.

The Newfoundland Academy of the Arts offered courses in portraiture (Helen's specialty), and drawing and painting for beginning children and adults as well as more seasoned artists, taught by the Shepherds and invited guest instructors; an art supply store; and living quarters for the Shepherds and their young son. ${ }^{99}$ The Shepherds took students outdoors to paint when weather permitted and exhibited their students' work at the Academy. ${ }^{100}$ The school was seen as a godsend for students, who would otherwise have had to travel quite some distance to study at the nearest art school in the region, the Nova Scotia College of Art in Halifax.

Reginald Shepherd, in addition to operating and teaching at the Academy, was Memorial University's first Specialist in Art from 1951 to 1961 and began an art therapy class at the nearby Waterford Hospital. Helen Shepherd's numerous portrait commissions kept her very busy during this time. In 1961 the couple closed the Academy to focus on their individual artistic pursuits, although Reginald continued to teach at Prince of Wales Collegiate until 1980. ${ }^{101}$

The Shepherds "generated a new level of interest in art in the province."102 That is not to say there were no supporters or artists before they arrived. More often than not, however, professional artists in Newfoundland before the 1950s were tourists, seasonal residents, or war artists. ${ }^{103}$ This could be why cultural producers in this isolated and independent province looked suspiciously upon central Canadians and the attempts of 
"Wise Men from Toronto," as former premier Joey Smallwood said, "bringing light into the wilderness." 104 Although art societies existed, such as the Old Colony Club (formerly the Ladies' Reading Room and Current Events Club, founded in 1899) and the Newfoundland Society of Art, their activities were sporadic and unsustained. During the Biennial Exhibition era, visual artists banded together in the St. John's Art Club (a loosely organization founded in 1940 with approximately forty active members and eighty associates as of 1949), centered on Memorial University, where a modest collection of art books, prints, and reproductions were maintained. ${ }^{105}$

The University opened an art gallery in its Arts and Culture Centre in 1961, and there exhibited work by its teachers and other Newfoundland artists, and travelling exhibitions drawn from the Maritime Art Association and other groups in the region. ${ }^{106}$ Christopher Pratt, a graduate of Mount Allison University and the future "Mondrian of Newfoundland", ${ }^{107}$ was the gallery's first director. In addition to curating, Pratt became the University's Specialist in Art and taught evening art lessons in a "dark, semisubterranean room" until 1963, when he quit to paint full-time at his studio in St. Mary's Bay on the south shore of the Avalon Peninsula. ${ }^{108}$

As urban centre, though, St. John's was relatively "rural" in comparison with urban centres in the rest of the country and groups here could not be compared to groups in metropolises elsewhere. ${ }^{109}$ Changes to transportation and communication infrastructure in the 1950s and 1960s decreased isolation within Newfoundland and brought the province into the fold of Canadian and American culture through radio and television programming. ${ }^{110}$ Greater cohesion among cultural producers led to increased activism for more and better visual arts infrastructure in Newfoundland and Labrador 
towards the end of the 1960's and into the 1970's, after the final biennial exhibition of Canadian art.

\section{Linking the Provinces}

The Maritime Art Association (MAA) was intrinsic to the tenacity and evolution of the visual arts in Atlantic Canada. This group single-handedly connected the four Atlantic provinces and attempted to educate the rest of the country on developments in Atlantic Canadian art. The MAA's development was part of a long chain of arts associations in the region, some of which can claim to be the first of their sort in the country. The Halifax Chess, Pencil and Brush Club, for example, founded in 1787 and active until 1817 , is considered the first artists' organization in Canada. ${ }^{111}$

The Maritime Art Association was founded in 1935 by seventeen art societies, university and college art departments, and galleries in the region to pool limited, Depression-era resources and support artists through networking and public education. Under the guidance of Walter Abell, who conducted a survey on member needs and became its first president, the MAA sponsored travelling regional and national exhibitions (with accompanying guidebooks) as well as lectures by art historians, and in 1940 commenced publishing the magazine Maritime Art, with Abell as editor. ${ }^{12}$

Abell, an American hailing from Philadelphia, had plans to augment and improve Maritimers' exposure to broader artistic developments and disseminate information on the region's artists to the rest of Canada. He became Acadia University's first professor of Art and Aesthetics in 1928, a position sponsored by the Carnegie Corporation. ${ }^{113}$ Abell brought a teaching collection of artwork to Acadia University and acquired works 
for its permanent collection before leaving in 1944. These were added to the portraits the University had accumulated of governors and prominent Wolfville residents. ${ }^{114}$

Initially, Maritime Art was "aggressively populist" and reflected its roots in the region through its subtitle: "The Journal of the Maritime Art Association". ${ }^{115}$ Carnegie Corporation funding supported a low per issue price (twenty-five cents), which permitted its sale to both the arts professional and the curious layman. Each issue included an original wood-block print. Articles and editorials discussed Maritime artists alongside Ontario ones, the Canadian Group of Painters and children's art, gave directions for techniques, posted calls for exhibition submissions and MAA news, and also called for government and private support of the arts. ${ }^{116}$ It seemed clear by the second volume that, eventually, the magazine would outgrow its local ties and focus more on Canadian art beyond the region when the subtitle became "A Canadian Art Magazine" in $1941 .{ }^{117}$

As editor, Abell championed art which was socially relevant in its subject matter, which to him was representational and described social and political reality. ${ }^{118}$ Over time, though, Abell's growing acceptance of abstract art saw Maritime Art reflect a broader community and feature, more heavily than regional artists, Canadian artists, including Paul-Émile Borduas, who were influenced by avant-garde European movements. ${ }^{119}$ This shift in Abell's stance signaled the demise of Maritime Art. Three years after its inception, the journal was no longer reflective of the MAA's regional constituency. Editing and publishing headquarters moved to Ottawa where the National Gallery of Canada (after numerous requests from Abell to gallery director H.O. McCurry to transform Maritime Art into a national periodical) assumed an administrative function 
and the journal was renamed Canadian Art. ${ }^{120}$ In its place, The Maritime Bulletin became the lone publication for arts in the easternmost provinces. ${ }^{121}$

The Maritime Art Association continued its work of uniting artists and educating the public. It received funding from New Brunswick, Nova Scotia, Prince Edward Island, and Newfoundland, as well as from the federal government to hold public art lecture series, publish The Maritime Bulletin monthly, organize an annual MAA travelling exhibition, and build a slide collection featuring Maritime fine arts and crafts. ${ }^{122}$ The Association held annual general meetings in various centres through the region, allowing individuals to get behind-the-scenes tours of member galleries and soak in the culture of cities and towns across the Atlantic provinces. The Association worked in conjunction with the National Gallery of Canada, regional art galleries, and local art clubs to bring travelling exhibitions to appropriate venues. This integral partnership and service brought professionally curated exhibitions of painting and sculpture to such isolated places as Woodstock New Brunswick's Fisher Memorial Library, Bridgewater's Centennial Des Brisay Museum, and Cape Breton's Sydney Academy in the 1960s. ${ }^{123}$ Travelling exhibitions were an important facet of art education in Atlantic Canada. They drew isolated artists together and connected them with other artists from their province, their region, and from across the country. Nova Scotia was particularly active in sending exhibitions to "almost every city, town, unincorporated village, and crossroad settlement" ${ }^{\prime 24}$ in the province through the Travelling Exhibitions of Nova Scotian Paintings program begun in 1947 and jointly sponsored by the Nova Scotia Society of Artists, the Nova Scotia College of Art and the Adult Education Division of the Department of Education. In this same year, the Nova Scotia College of Art began 
organizing and circulating its own travelling exhibitions throughout the province as the Nova Scotia Society of Artists had done since 1926. ${ }^{125}$

Exhibition exchanges from across the country also connected artists and communities. For example, in 1949 the Maritime Art Association and the Western Art Circuit cooperated to exchange exhibitions, giving two regions a chance to examine each other's visual art. Each region deemed to the other's art to be conservative. ${ }^{126}$ Apart from some National Gallery of Canada travelling exhibitions, during the 1950s and 1960s Atlantic Canada received exhibitions from the Canadian Society of Painters in Water Colour as well as UNESCO and the C.I.L. corporate collection. ${ }^{127}$

In some instances, invitations to exhibit came from unusual sources. A letter from Nova Scotia's chief hotel inspector, Jean Ross, to NSSA president Ralph Cowen urged artists to exhibit their work in motels and hotels throughout the province in order to draw tourists' attention to painting in the province. To encourage cooperation and dialogue between artists and hotel operators, Ross offered artists an exhibition booth in a hotel operator's training session for a fee. ${ }^{128}$

Summer workshops were a way for artists in the region who, for various reasons, could not travel for training, to maintain contact with contemporary artists and currents in art and learn new techniques. Montreal artist Gentile Tondino was an arts educator who drew artists to the small town of Tatamagouche, outside Halifax. His workshops were popular and filled quickly. ${ }^{129}$ Many of the universities previously discussed offered summer workshops as well. At the University of New Brunswick, for example, Pegi Nicol MacLeod led groups of student outdoors to paint. ${ }^{130}$ It is unfortunate that a remote 
area in Atlantic Canada did not become a major centre for cutting edge art education and critical exploration. Such a situation could have been encouraging and stimulating.

\section{Impact of Mid-Twentieth Century Arts Infrastructure in Atlantic Canada}

In the 1950s and 1960s Nova Scotia, Prince Edward Island, and Newfoundland could have benefitted from plans to decentralize the National Gallery, as proposed by Lawren Harris on behalf of the Federation of Canadian Artists. Had the region relied on Ottawa to provide its cultural infrastructure, however, the determination of visual artists and their supporters in these provinces may not have taken the diverse, intertwined forms it did. In Atlantic Canada today, university, provincial, artist-run, and commercial art galleries work together. Such cooperation is a direct result of the sincere desire and ingenuity of individuals who wished to see the visual arts flourish in the region.

During the mid-twentieth century, however, the "undercurrent of activity"131 discernable throughout the region had yet to manifest itself in substantial ways such as state-of-the-art museums or large exhibitions that attracted attention from beyond the region. The provincial governments in Atlantic Canada worked hard to ensure other Canadians viewed the region as anti-modern and traditional in an effort to encourage tourism. The tourism industry was far more financially important at the time than contemporary fine arts. As this chapter has demonstrated, though, many individuals and associations in the region made or were making significant progress in bringing visual arts to the Atlantic Canadian public through exhibitions, classes, and lectures. These influential players also made efforts to inform other Canadians about the region's art through exhibition exchanges and by inviting artists to have a presence at universities and teach workshops. It is vital to recognize this rich history of arts infrastructure in Atlantic 
Canada before examining the region's inclusion in the biennial exhibitions of Canadian art. 
Endnotes

'Grade "A" Galleries are defined as having both elements. excerpt from letter to Charles Comfort from unknown, 30 January 1951, Annual Exhibition of Canadian Art 1953, File 5, Exhibitions in Gallery, NGC fonds, National Gallery of Canada Library and Archives (hereafter cited as NGA).

${ }^{2}$ Attempts by the NGC to reach out to the regions were successful only in areas that had galleries. Doris Shadbolt, "Coast to Coast in Art: An Important Conference on Galleries and Art Education," Canadian Art 14, no. 1 (Autumn Number, 1957): 35. Failing the ability to borrow actual art, the NGC made slides and films on art available for up to six months or a year for the cost of transportation. Minutes of the Annual Convention of the Maritime Art Association (hereafter cited as MAA) 1962-63, MG 20, Vol. 501, File 5, Nova Scotia Archives and Records Management (hereafter cited as NSARM).

${ }^{3}$ Claude Picher to the MAA Conference, 1957-1965 Report of MAA Conference Moncton to Nova Scotia Society of Artists (hereafter cited as NSSA), 19 May 1961, Vol. 501, File 5: NSSA, MAA Annual Conference, NSARM.

${ }^{4}$ Lola Mould, for example, notes in an invitation to her Halifax show at the Granville Art Galleries in April 1966, "I've exhibited in centres across Canada and in Boston and New York but this will be the first time in Halifax." Letter from Lola Mould to President of NSSA, 3 February 1966, MG 20, Vol. 500, File 4, NSARM. In the 1920's Jack Humphrey had exhibited with the New York Water Color Society and the Philadelphia Water Color Club before his first exhibition at the New Brunswick Museum in 1949. Russell Harper, Jack Humphrey: A Painter in the Maritimes (Fredericton: The Beaverbrook Art Gallery, n.d.), 1012. LeRoy Zwicker had by 1945 exhibited in Paris and London. Information Form, NGC, 2 April 1945: < http://cybermuse.gallery.ca/cybermuse/servlet/imageserver?src=DO9375\&ext=x.pdf.>

${ }^{5}$ Alfred Whitehead of the Amherst Art Society notes, in a letter to Mrs. Keddy, Secretary of NSSA, his displeasure over the inconveniences faced by painters living in remote areas. For example, suitable framing was difficult to acquire and the inability to secure this was a factor affecting submissions to juried exhibitions. 14 February 1957, MG 20, vol. 499, File 5, NSARM.

${ }^{6}$ A. Whitney Griswold, "The Natural Allies," in The Fine Arts and the University (Toronto: The MacMillan Company of Canada Limited, 1965), 9. This was originally printed in The Atlantic Monthly under the title "The Fine Arts and the University".

${ }^{7}$ Canada, Dominion Bureau of Statistics, 1961 Census of Canada: General Review: Rural and Urban Population, Bulletin 7.1-2 (Ottawa: The Minister of Trade and Commerce, 1963), 2-7, Table IV.

${ }^{8}$ Jack Humphrey, "The Problem of the Artist in the Maritimes," Canadian Art 12, no. 2 (Winter 1955): 6972.

9 John G. Reid, "The 1920's: Decade of Struggle," in The Challenge of Modernity: A Reader on PostConfederation Canada, ed. Ian McKay (Toronto: McGraw-Hill Ryerson Ltd., 1992), 246-257.

${ }^{10}$ Ian McKay has written extensively about the pre-modern, nostalgic, and touristic narrative developed in Nova Scotia to support tourism. McKay notes that this mythologizing developed "partly in response to a public hungry for a reassuring presence of the past... a narrative which acquired the cumulative force of truth, as one generation's invented tradition became the next generation's commonsense reality." Ian McKay, "History and the Tourist Gaze: The Politics of Commemoration in Nova Scotia, 1935-1964," in Atlantic Canada after Confederation, ed. P.A. Buckner, Gail G. Campbell, and David Frank, The Acadiensis Reader, vol. 2, 3rd ed. (Fredericton: Acadiensis Press, 1999), 414-416.

James Overton notes that Nova Scotia and Newfoundland's tourism promotion was nearly identical into the 1920s. After that decade, Newfoundland placed more emphasis on becoming a health-restoring, therapeutic space rather than a recreational one. James Overton Making a World of Difference: Essays on Tourism, Culture and Development in Newfoundland (St. John's: Memorial University of Newfoundland Institute of Social and Economic Research, 1996), 12-19.

${ }^{11}$ Andrew S. Harvey and W. Stephen Macdonald, Evaluation of the Brudenell-Mill River Tourist and Recreation Complexes Embodied in the Prince Edward Island Development Plan (Halifax: Dalhousie University Institute of Public Affairs: Regional and Urban Studies Centre, 1974), I-1.

${ }^{12}$ Overton, 11.

${ }^{13}$ Huia Ryder, "Contemporary Handicrafts," in Arts in New Brunswick (Fredericton: University Press of New Brunswick Ltd., 1967), 268. McKay, "Handicrafts," 119. 
${ }^{14}$ Along with emphasizing traditional hand crafts, exaggerating Scottish ties and the relevance of Scottish forms such as tartan (historically worn only by clans) to all Nova Scotian citizens occurred. Mary Black, Nova Scotia premier Angus L. MacDonald, and English embroiderer Bessie Murray (who was hired by Black), actively promoted the province's romanticized association with Scotland by creating a Nova Scotian tartan in 1953. Devising, weaving, advertising, and selling this tartan (which had financial value not only in Nova Scotia but in England and New York) exemplified the invented link between regional crafts, commerce, and tourism in the province. McKay, "Handicrafts," 117-129.

${ }^{15}$ Ian MacKay, The Quest of the Folk: Antimodernism and Cultural Selection in Twentieth-Century Nova Scotia (Montreal and Kingston: Queen's University Press, 2006), 185.

${ }^{16}$ Ryder, "Contemporary Handicrafts," 119.

${ }^{17}$ Ian McKay "Handicrafts and the Logic of 'Commercial Antimodernism': The Nova Scotia Case," in Antimodernism and Artistic Experience: Policing the Boundaries of Modernity, ed. Lynda Jessup (Toronto: University of Toronto Press, 2001), 119-122. See also Huia Ryder, "History of Handicrafts," Arts in New Brunswick (Fredericton: University Press of New Brunswick Ltd., 1967): 237.

${ }^{18}$ Creighton was actively promoting these views to Canadians through the CBC show Telescope as late as 1966. Helen Creighton, A Life in Folklore (Toronto: McGraw-Hill Ryerson Limited, 1975), 232.

${ }^{19}$ Ian McKay, "Helen Creighton and the Politics of Antimodernism," in Myth and Milieu: Atlantic Literature and Culture - 1918-1939, ed. Gwendolyn Davis (Fredericton: Acadiensis Press, 1993), 4-6. ${ }^{20}$ Ibid., 6-8.

${ }^{21}$ To safeguard the supposed purity of these isolated Folk people from the modern world, Creighton promoted the Folk through the very modern mediums of radio and magazines, as well as published books of ghost stories, songs, and tales and bemoaned the rise of industries which would bring work and comfort to her "Folk" but dilute their purity in her mind. Further demonstrating the purity she sought in these people, Creighton deleted "lewd" words and phrases recorded during her sessions with these folk people which did not suit her tastes. Ibid., 8-9.

${ }^{22}$ Creighton, 238.

${ }^{23}$ A review of the histories of the Nova Scotia College of Art and Design University and the Nova Scotia Society of Art shows a long history of assorted squabbles and disagreements within both groups on the best approaches to meeting shared art education and exhibition goals. See Donald Soucy and Harold Pearse, The First Hundred Years: A History of the Nova Scotia College of Art and Design (Fredericton and Halifax: University of New Brunswick and NSCAD, 1993) and MG 20, Vols. 207 - 503, NSARM. ${ }^{24}$ The founding of the MAA in 1935 and the Atlantic Provinces Art Gallery Association in 1975 were major events influencing the communal support and assistance art galleries and artists.

${ }^{25}$ For Garry Neill Kennedy's account of his perception of the College and Nova Scotian art in 1967 see Kennedy's "NSCAD and the Sixties," Conceptual Art: The NSCAD Connection 1967-1973, ed. Bruce Barber (Halifax: Nova Scotia College of Art and Design, 2001), 20-31.

${ }^{26}$ Lord Beaverbrook, 26 October 1959. Beaverbrook Art Gallery, "50th Anniversary Celebrations": $<\mathrm{http} / / / \mathrm{www}$. beaverbrookartgallery.org/main-e.asp?207>.

${ }^{27}$ This room was used to host travelling regional exhibitions as well. Letter from R.A. Tweedie to Mrs. M.J. Keddy, 18 November 1957, MG 20, Vol. 499, File 5, NSARM.

${ }^{28}$ New Brunswick Museum, "Humanities Collection: Beyond New Brunswick - International" (Saint John, New Brunswick: New Brunswick Museum, 2008). <http://www.nbm-mnb.ca/index.php?option= com_wrapper\&view $=$ wrapper\&Itemid $=563>$.

${ }^{29}$ See Lianne McTavish's study of the the National History Society's pedagogical methods, "Learning to See in New Brunswick, 1862-1929," The Canadian Historical Review 87, no. 4 (December 2006): 553581.

${ }^{30}$ New Brunswick Museum, "New Brunswick Museum History" (Saint John, New Brunswick: New Brunswick Museum, 2008). <http://www.nbm-mnb.ca/index.php?option=com_content\&view=article\&id= 59\&Itemid $=251>$.

${ }^{31}$ Avery Shaw, "Painters of New Brunswick," Canadian Art 11, no. 4 (Summer 1954): 151.

${ }^{32}$ John G. Reid, Mount Alison University: A History, to 1963, Vol. 1: 1843-1914 (Toronto: University of Toronto Press for Mount Allison University, 1984), 208.

${ }^{33}$ Ibid., 112-113, 174.

${ }^{34}$ Ibid., Vol. 1, 208-210 and Vol II: 1914-1963, 19.

${ }^{35}$ Ibid., Vol I, 197, 258. 
${ }^{36}$ Owens Art Gallery, History (Sackville: Mount Allison University, 2010):

$<$ http://www.mta.ca/owens/history/index.php>.

${ }^{37}$ This effort would have paired brilliantly with the tourism promotions developed in the region by the provincial governments. Reid, Vol. I, 258.

${ }^{38}$ Ibid.

${ }^{39}$ Dennis Reid, A Concise History of Canadian Painting, $2^{\text {nd }}$ ed (Toronto: Oxford University Press, 1988), 273, 338. See also Cliff Eyland, ATQUE ARS, catalogue essay for Tantramar City: Contemporary Painting by Mount Allison Associates, curated by Cliff Eyland, Charlotte Townsend Gault and Gemey Kelly (Sackville: Owens Art Gallery, 1989).

${ }^{40}$ Josée Drouin-Brisebois, "Christopher Pratt in the Political Landscape," in Josée Drouin-Brisebois Christopher Pratt: All My Own Work (Ottawa: National Gallery of Canada / Douglas \& McIntyre, 2005), 40.

${ }^{41}$ Pegi Nicol MacLeod taught summer art classes in Fredericton from 1941-1948. The artist is buried in the nearby Forest Hill Cemetery. Susan Montague, A Pictorial History of the University of New Brunswick (Fredericton: The University of New Brunswick, 1992), 130, 138.

${ }^{42}$ NSSA, MAA - Minutes of Annual and Executive Meetings, 1954-1961; MAA Reports and Minutes of the Annual Meeting, Year 1954-55, MG 20, Vol. 501, File 6, NSARM. See also Montague, 186.

${ }^{43}$ Montague, 148, 186.

${ }^{44}$ Desmond Pacey, "Coast to Coast in Art: The Maritimes," Canadian Art 18, no. 6 (November/December 1961): 424.

${ }^{45}$ UNB Art Centre, Fact Sheet, sent to author by Marie Maltais (Fredericton: UNB Art Centre, 2010).

${ }^{46}$ Saskatchewan Council for Archives and Archivists, "Educational Institutions: University of

Saskatchewan," Saskatchewan and the Visual Arts: an Exhibit, online exhibition (Saskatoon: Saskatchewan Council for Archives and Archivists, 2001): < http://scaa.sk.ca/gallery/art/educational-uofs.html>.

${ }^{47}$ UNB Art Centre, Fact Sheet.

${ }^{48}$ Galerie d'art Louise-et-Ruben Cohen de l'Université de Moncton, "Claude Roussel," in Artothèque : Overview of Contemporary Art in Acadia (Moncton: RCIP and Galerie d'art Louise-et-Ruben Cohen de l'Université de Moncton, 2006): <http://www2.umoncton.ca/cfdocs/artotheque/EN/18/Biographie.pdf>. See also Benjamin Higgins, Impact of the Université of Moncton on the Regions of Moncton, Edmunston and Shippagan (Moncton: Institut Canadien de Recherche sur le Développement Régional, 1988), 7-8 for a brief discussion of the University's involvement with French films, theatre and music.

${ }^{49}$ Bulletin of Maritime Art News, March 1964, MG 20, Vol. 501, File 2, NSARM.

${ }^{50}$ Letter D. Edwin Campbell to Mrs. F.G. Welland, 24 January 1958, MG 20, Vol. 499, File 6, NSARM.

${ }^{51}$ Bulletin of Maritime Art News, March 1964, MG 20, Vol. 501, File 2, NSARM; NSSA, MAAConstitution, Membership Lists, Correspondence 1957-1967, MG 20, Vol. 501,File 7, NSARM. See also Annual Reports 1961-1964 and NSSA 1961-1962 reports, MG 20, Vol. 499, File 1, NSARM.

${ }_{52}$ The South Shore Art Centre's existence was recorded for posterity through correspondence with the Nova Scotia Artists' Association in 1958, although no other information can be traced about it. Letter from Mary Elizabeth Goodell to Mr. [sic, Mrs.] Wellard, n.d., predates a 1958 Annual NSSA Exhibition, MG 20, Vol. 499, File 7, NSARM.

${ }^{53}$ See NSSA Minute Books \& Scrapbooks 1922-1972, MG 20, Vol. 502 and Exhibition Notices and Catalogues 1938-1972, MG 20 Vol. 503, NSARM.

${ }^{54}$ Artist and NSSA President, Catherine Beecher Weld wrote "I really believe that most of our members are very serious in their artistic efforts and that the errors of carelessness and inertia that have crept in are due mostly to our isolated position, and that a good many of them would be much sharper artists in a more competitive area." Letter from C. Beecher Weld to Prof. Martin Kemp, 18 February 1966, MG 20, Vol. 500 , File 4, NSARM.

${ }^{55}$ Marjorie H. Webber, President of the Nova Scotia Museum of Fine Arts (hereafter cited as NSMFA) noted that "Since acquiring more paintings we are ever mindful of the fact that we need a proper fireproof Gallery of our own." November Meeting Minutes, 1957, NSMFA Book Volume III, Vol. IV, MG.20, vol. 208, NSARM. 
${ }^{56}$ Donald Crowdis, Director of the Nova Scotia Museum, spoke to NSMFA members of the rumors circulating in Nova Scotia about a possible Sir James Dunn Art Centre being built in Halifax. He noted that the word from abroad was that this was not a possibility. Instead, Dalhousie University was the recipient of the goodwill of Lady Dunn (a fascinating figure tied to Atlantic Canada through her marriages to New Brunswick natives, Sir James Hamet Dunn and Lord Beaverbrook) and saw the Sir James Dunn Science Building constructed in 1960 instead. Executive Meeting Minutes, 18 March 1960, NSMFA Minutes Vol. VI, MC 20, Vol. 209, NSARM. See Dalhousie University, "The Buildings of Dalhousie University: Sir James Dunn Building," Dalhousie University Archives and Special Collections, Digital Collections: <http://www.library.dal.ca/duasc/buildings/Dunn.htm> and also Peter B. Waite, The Lives of Dalhousie University: Volume II: 1925-1980, The Old College Transformed (Montreal: McGill-Queen's University Press, 1997), 206-227.

${ }^{57}$ Letter from Verna Holmes to Prof. M. A. Usiami, 30 September 1964, MG 20, Vol. 500, File 3, NSARM.

${ }^{58}$ Letter from The Nova Scotia Museum of Fine Arts, the Nova Scotia Society of Artists, and the Halifax Picture Loan Society to Dr. H.P. Moffat, Deputy Minister of Education, 21 September 1962, MG 20, Vol. 499, File 11, NSARM.

59 "Coast to Coast in Art," Canadian Art 11, no. 2 (Winter 1954): 76.

${ }^{60}$ Ibid.

${ }^{61}$ Letter from Marjorie H. Webber to NSMFA reporting on MAA Annual General Meeting, St. John, 26-27 May 1955, MG.20 vol. 208, NSMFA Book Volume III, Vol. IV, NSARM.

62 "Coast to Coast in Art," Canadian Art 11, no. 2 (Winter 1954): 76.

${ }^{63}$ Ruth Wainwright was the first artist featured in this series, followed by Robert Annand, both of whom were featured in the Biennial Exhibitions of Canadian Art. For more information on this series, see NSSA Exhibition Catalogues and Invitations 1942-59, MG 20, Vol. 500, File 1, NSARM. See also letter from Mirko A. Usmiani to Grace Keddy, 18 January 1961, MG 20, Vol. 499, File 10, NSARM.

${ }^{64}$ The Dalhousie Arts Centre was the first cultural centre in the province since the 1700's. See Dalhousie University, "The Buildings of Dalhousie University: Dalhousie Arts Centre," Dalhousie University Archives and Special Collections, Digital Collections:

<http://www.library.dal.ca/duasc/buildings/ArtsCentre.htm>

${ }^{65}$ Soucy, 4.

${ }^{66}$ Ibid., 71-75.

${ }^{67}$ Ibid., 141. Leonard Kitz originally quoted in The Christian Science Monitor, March 15, 1957.

${ }^{68}$ NSSA Correspondence 1958-1959, MG 20, Vol.499, File 7, NSARM.

${ }^{69}$ See NSSA Exhibition Catalogues, Annual Exhibitions 1961-1964, MG 20, Vol. 500, File 11, NSARM.

${ }^{70}$ Soucy, 144.

${ }^{71}$ Ibid.

${ }^{72}$ Ibid., 144, 147.

${ }^{73}$ Ibid., 144.

${ }^{74}$ Kennedy, 20-22.

${ }^{75}$ Mora Dianne O'Neill, Paintings of Nova Scotia: From the Collection of the Art Gallery of Nova Scotia (Halifax: Art Gallery of Nova Scotia, 2004), xi-xiii and Soucy, 149.

${ }^{76}$ O'Neill sees the landscape as the essence and raison d'être of Nova Scotian painting before the 1970's.

${ }^{77}$ Kennedy, 20.

${ }^{78}$ Soucy, 148-149 and Kennedy, 20.

${ }^{79}$ Discussions and debates on the aesthetic value of Modern art were held in Halifax in the 1950's and 1960's. One meeting saw the NSMFA debate the NSSA on this topic. See Annual Meeting, 12 January 1950 and General Meeting Notes 8 April 1958, President's Report, MG.20, vol. 208, NSMFA Book Volume III, NSARM. Eric Newton lectured on Modern Art at Dalhousie University and the MAA solicited further lectures in the region on his behalf. See Minutes of General Meeting, 8 October 1955, MG.20, vol. 208, NSMFA Book Vol. IV, NSARM.

${ }^{80}$ Dalhousie University Art Gallery celebrated and educated on local abstract art through its "Know Your Artists" exhibition series which included these Nova Scotian artists.

${ }^{81}$ Kennedy, 20.

${ }^{82}$ Kennedy, 20-22. 
${ }^{83}$ Soucy, 144-149. See Kennedy's account of The Halifax Conference in Kennedy, 22-23.

${ }^{84}$ Laura A. Master (NGC) to Mrs. Henderson (PEISA), 15 August 1955, First Biennial Exhibition of Canadian Painting, Box 178, File 3, NGA.

${ }^{85}$ Frieda I. Crulman to Mrs. F. G. Welland, 9 February 1958, MG 20, Vol. 499, File 6, NSARM.

${ }^{86}$ Confederation Centre Art Gallery and Museum (Charlottetown: Confederation Art Gallery, 1969), 1.

${ }^{87}$ A.L. Tunnell, Canadian Who's Who: 1961-1963, Vol IX (Toronto: University of Toronto Press, 1963), 726.

${ }^{88}$ Confederation Centre Art Gallery and Museum, 11.

${ }^{89}$ Ibid., 1 and catalogue section, 24-37.

${ }^{90}$ Ibid., 4-15.

${ }^{91}$ See Kieran Simpson, Canadian Who's Who: 1985, Volume XX (Toronto: University of Toronto Press, 1985): 1317.

${ }_{92}$ It could also be argued that, like many cultural administrators before him who "came from away", Williamson bore a patronizing attitude towards Atlantic craftspeople. He had characterized some of their work as gimmicky, but was aware of the anti-modern folk myth surrounding them and sensed that this was restrictive and imposed. Sandra Alfoldy, "Moncrieff Williamson, Maritime Regionalism, and the Dream of a National Craft Museum," Journal of Canadian Art History 28 (2007): 42, 50.

${ }^{93}$ Ibid., 43.

${ }^{94}$ Ibid., 43-47.

${ }^{95}$ Ibid., 47, 49.

${ }^{96}$ By 1971 there were fewer than twenty-four professional artists in the province's capital. Patricia Grattan, The Power of Place: St. Michael's Printshop and 30 Years of Printmaking in Newfoundland (St. John's:

Art Gallery of Newfoundland and Labrador/St. Michael's Printshop, 2004), 56.

${ }^{97}$ Tom Smart, The Art of Fred Ross (Fredericton: The Beaverbrook Art Gallery, 1993), 15-17.

${ }^{98}$ Patricia Grattan, "Foreword," in Rethinking the Rural in Contemporary Art (St. John's: Art Gallery of Newfoundland and Labrador, 1997), 4. Published in conjunction with Rethinking the Rural in Contemporary Art shown at the Art Gallery of Newfoundland and Labrador, St. John's.

${ }^{99}$ Peter Gard, "Reginald and Helen Parsons Shepherd," in Helen Parsons Shepherd and Reginald Shepherd: Four Decades (St. John's: Art Gallery, Memorial University of Newfoundland, 1989), 6.

Published in conjunction with Helen Parsons Shepherd and Reginald Shepherd: Four Decades shown at the Art Gallery, Memorial University of Newfoundland.

${ }^{100}$ Ibid.

${ }^{101}$ Ibid., 6-8.

${ }^{102}$ Ibid., 6.

${ }^{103}$ Robert Ayre, “Art in Newfoundland," Canadian Art 7, no. 1 (Autumn 1949): 18-19.

${ }^{104}$ Mavor Moore, "No Province is an Island, Entire of Itself," The Globe and Mail, June 2, 1984.

${ }^{105}$ Ayre:19-20. No dates are given for the dissolution of the Ladies' Club or the founding and demise of the Newfoundland Society of Art.

${ }^{106}$ Christopher Pratt was Memorial University's Specialist in Painting and was selected to serve on the Fifth Biennial of Canadian Painting's Honorary Committee before leaving this post to paint full-time in 1963. Letter from Christopher Pratt to Russell Harper, 24 June 1963, Fifth Biennial Exhibition of Canadian Painting, Box 454, Volume 6, NGA.

${ }^{107}$ Jeffrey Spalding, "A Brief Foray into the World of Christopher Pratt," in Josée Drouin-Brisebois Christopher Pratt: All My Own Work (Ottawa: National Gallery of Canada / Douglas \& McIntyre, 2005), 16.

${ }^{108}$ Christopher Pratt: Personal Reflections on a Life in Art, introduction by David Silcox (Toronto: Key Porter Books Ltd., 1995), 25.

${ }^{109}$ Cliff Eyland, "Rethinking the Rural in Contemporary Newfoundland Art," in Rethinking the Rural in Contemporary Newfoundland Art (St. John's: Art Gallery of Newfoundland and Labrador, 1997), 6.

Published in conjunction with Rethinking the Rural in Contemporary Newfoundland Art shown at the Art Gallery of Newfoundland and Labrador, St. John's.

${ }^{110}$ For more information see Ralph Matthews, "The Smallwood Legacy: The Development of Underdevelopment in Newfoundland, 1949-1972”, Journal of Canadian Studies 13, no. 4 (1978-79): 89106. 
${ }^{111}$ Laurier Lacroix, "Artists' Organizations," The Canadian Encyclopedia (Historica Foundation, 2010): $<$ http://www.thecanadianencyclopedia.com/index.cfm?PgNm=TCE\&Params=a1 ARTA0000340>.

112 Julia Scalzo, "Walter Abell: From Maritime Art to Canadian Art," Vanguard 16, no. 1 (February-March 1987): 20.

${ }^{113}$ In "Coast to Coast in Art" Abell is said to have come to Canada to teach in 1937. Canadian Art 13, no. 3 (Spring 1956): 306. Scalzo's date of 1928 seems more accurate, considering he would have had more time to conduct research on Maritime art if arriving then. Scalzo, 20.

${ }^{114}$ Acadia University, although owner of a permanent collection, did not maintain an art gallery until 1978. Acadia University Art Gallery, "Permanent Collection History," Acadia University Art Gallery (Wolfville: Acadia University Art Gallery, 2010): <http://gallery.acadiau.ca/Acadia_Art_Gallery/history.html>.

${ }^{115}$ Scalzo, 20-21.

${ }^{116}$ Scalzo, 20.

${ }^{117}$ Ibid. See also the exhibition catalogue accompanying which attributes the subtitle's addition to Abell's active involvement in the Kingston Conference of Canadian Artists in 1941. Steven MacNeil, Library and Archives Exhibition No. 13: Maritime Art: Canada's First Art Magazine, 1940-1943 (Ottawa: National

Gallery of Canada, 2002), 3.

${ }^{118}$ Scalzo, 21-22.

${ }^{119}$ Scalzo, 22-23.

${ }^{120}$ MacNeil, 4.

${ }^{121}$ NSMFA Annual Report for Year Ending December 1943, MG 20, Vol. 207, Minute Book of NSMFA, Vol II, NSARM.

122 "Coast to Coast in Art," Canadian Art 10, no. 4 (Summer 1953): 167. According to this text, in 1953, financial support was divided as follows: $\$ 300$ from New Brunswick and Nova Scotia each, $\$ 100$ from Prince Edward Island, and $\$ 700$ from the Federal Government. The federal funding body is not noted. See also MAA Newsletters, Bulletins, 1964-1966 and MAA News, 30 September 1965, MG 20, Vol. 501, File 2, NSARM.

${ }^{123}$ MAA Newsletters, Bulletins, 1964-1966 and MAA News April 1966, MG 20, Vol. 501, File 2, NSARM.

${ }^{124}$ NSSA Exhibition Catalogues and Invitations 1942-59, MG 20, Vol. 500, File 1, NSARM.

125 Soucy, 141. See also NSSA Minute Books \& Scrapbooks 1922-1972, MG 20, Vol. 502, NSARM and NSSA Exhibition Notices and Catalogues 1938-1972, MG 20, Vol. 503, NSARM.

${ }^{126}$ Charles H. Scott and Lucy Jarvis, "Paintings from East and West," Canadian Art 6, no. 4 (Summer 1949): 167-170.

${ }^{127}$ Letter from Mirko A. Usmiani to Grace Keddy, 18 January 1961, Nova Scotia Society of Artists MG

20, Vol. 499, File 10, NSARM. See also MAA Newsletters, Bulletins, 1964-1966, MAA News April 1966,

MG 20, Vol. 501, File 2, NSARM. C.I.L. is a Canadian paint company in operation since 1926.

${ }^{128}$ Letter from Jean Ross to Ralph Cowen, 14 January 1958, MG 20, vol. 499, File 6, NSARM.

129 J. Patrick MacAdam, Division Secretary, NS Dept of Education, to "Friend" (form letter for NSAA members), February 9, 1959, MG 20, vol. 499, File 7, NSARM.

${ }^{130}$ Montague, 130.

${ }^{131}$ General Meeting Minutes, 12 November 1963, MG 20, NSMFA Minutes Vol. VI., NSARM. 


\section{Chapter 2}

\section{The Biennial Exhibitions of Canadian Art and Atlantic Canadian Representation} (1953-1957)

This chapter explores the origins of the forces shaping the National Gallery of Canada's seven biennial exhibitions of Canadian art and begins documenting Atlantic Canadian representation in the series from its inception in the Annual Exhibition of 1953 to the Second Biennial Exhibition of 1957. The major challenges plaguing the series take root during these these formative years when debates began among organizers about selection methods, quantity and types of works to include, and touring. The National Gallery's responses to these challenges reflected its changing status and the goals of its administration from 1953 to 1957 . Atlantic Canadian representation in these exhibitions reflects the Gallery's shifting priorities. Communication between organizers, regional selection committee members, and jurors, responses from artists and art critics on regional inclusion and characterization, along with catalogue texts and marginalia, are studied to give the reader an understanding of the unique circumstances surrounding these shows.

\section{The Biennial Exhibition Series is Conceived}

Although the First Biennial Exhibition of Canadian Painting occurred in 1955, its antecedent was the 1953 Annual Exhibition of Canadian Painting, which marked the beginning of the biennial series. The 1953 Annual Exhibition was a reincarnation of the annual exhibition series originally held from 1926 to 1933 . That series allowed the trustees to view a wide range of contemporary Canadian painting, sculpture, and graphic 
work for potential acquisition. Art was drawn from regional and national art society exhibitions and was chosen by an informal jury comprised of the National Gallery of Canada's director, a member of the National Gallery Board of trustees, and a senior representative from a Canadian art society. The program terminated during the Depression due to budgetary restrictions. ${ }^{1}$

Following the 1951 release of the momentous report written by the Royal Commission on National Development in the Arts, Letters, and Science (commonly referred to as the Massey Commission), the National Gallery was eager to capitalize on growing national awareness of the visual arts, generated by the Commission's nationwide interviews and its subsequent report. The Commission's report positioned the National Gallery as a beacon of Canadian culture for arts institutions across the country, demonstrating the role that visual arts could play in developing and confirming nationalist pride and unity. Through its programming, the report indicated that the Gallery would also become a status symbol for the country, providing "a value to the nation that extended beyond... particular cultural interests." ${ }^{2}$ A regular survey of contemporary Canadian art, like the annual exhibitions, would help satisfy this objective.

Several other developments in the early 1950s also fostered the revival of annual survey exhibitions of Canadian art. The Massey Commission's findings led to the 1951 creation of The National Gallery Act. The Act established an augmented post-war acquisition budget, gave the Gallery a more flexible purchase account which aided longterm acquisition planning, and increased the director's and board of trustees' authority to negotiate with the Treasury Board should important acquisition opportunities arise. ${ }^{3}$ The optimism encouraged by the Act, coupled with calls from trustee Dr. Robert Newton for 
increased purchases from Western Canadian artists, led the board of trustees to approve a reinvigorated incarnation of the annual exhibitions of Canadian art during its October 4, 1950 meeting. The series would encourage purchases of contemporary Canadian art (which the Gallery could now afford) and support the country's artists in a very visible manner.

The board of trustees appointed its newest member, distinguished painter Lawren S. Harris (appointed in 1950), as annual exhibition organizer in cooperation with Gallery director, Harry Orr McCurry. And although the ideological battles waged by these two seminal figures were repeated by diverse individuals throughout the series' life, they were never as fervently contested as they were between Harris and McCurry in the series' earliest days.

Preliminary meetings in 1950 between McCurry and Harris resulted in an outline of selection methods, criteria and hopes for the annual exhibition program. Conceptually, the program evolved (ambitiously) into a series of eight annual exhibitions designed to prompt public discussion on themes of art and nationalism, the interaction of artists and communities, and even the role of the National Gallery itself. ${ }^{4}$ Among the innovative strategies developed for this series, Harris recommended a new selection method that relied upon the guidance of local art experts in five culturally strategic Canadian regions: the Maritimes, Québec, Toronto, Ottawa, and the Prairies. By 1951, these regions were augmented to include British Columbia and Ontario along with the Maritime Provinces (or more accurately the Atlantic provinces, including Newfoundland), Québec, and the Prairies. ${ }^{5}$ Local experts including various curators, dealers, artists, and educators formed regional selection committees for the exhibition - for example artists Arthur Lismer and 
Jacques de Tonnancour in Québec; Sydney Key (curator of the Art Gallery of Toronto), Douglas Duncan, Gerard Brett (University of Toronto professor and director of the Royal Ontario Museum's Archeology Department) in Toronto; painters L.L.FitzGerald and Stanford Perrott (in Manitoba and Alberta, respectively); and Richard Simmins (curator of the Regina College Gallery) and painters Fred Amess, W.P. Weston, and Orville Fisher in British Columbia. ${ }^{6}$ Robert Newton challenged this method and called for an open invitation to Canadian artists instead (an idea later to be instituted in 1961 and promptly scrapped). ${ }^{7}$ Demonstrably, selecting works in a fair way was a challenging issue for exhibition organizers.

Trustees protested the lack of centralized authority in Harris and McCurry's proposed plan for regional selection committees, an authority which previous annual exhibition juries had enjoyed. McCurry and Harris felt strongly that cooperation with the country's regional art societies would be best supported by relying upon local experts, who would in turn give regional artists a stronger voice on this national platform. ${ }^{8}$ Harris argued that regional selection methods would also allow National Gallery trustees to view and acquire what they deemed to be the most outstanding and innovative works completed across Canada more efficiently than the previous, centrally-located juries had permitted.

In theory, reliance on regional committees, as initially designed, could have positively shaped the annual series. Regional experts could have communicated their vision of their best art and advanced their views of the role played by the regions in the development of Canadian art and nationalism. In practice, dialogue among the regions about art and nationalism never occurred and the National Gallery advanced its curators' 
views on these topics. A critical framework was certainly not suggested to the regional committees, which received "no special instruction" and were thought to operate best with "the freest possible hand". ${ }^{9}$ However, National Gallery trustees and exhibition organizers in fact maintained considerable control over the sort of work submitted for inspection and possible inclusion in the series, with selected trustees acting as regional selection committee chairmen in the annual exhibition of 1953 and the first biennial in 1955.

Furthermore, established networks of contacts were relied on by chairmen (including Jean Chauvin, A.Y. Jackson, Alvan C. Eastman, Norah McCullough, and Lawren S. Harris) when it came to forming committees, and a measure of exclusivity was thus involved in the selection process. ${ }^{10}$ No documented communication survives between trustees and the regional committees regarding why certain works were sent to Ottawa. From these submitted works, the trustees selected art demonstrating the undefined and subjective quality of "artistic merit" with no information regarding their importance within the region from which they originated. ${ }^{11}$

New Brunswick resident, Newfoundlander by birth, Mount Allison University president, and Gallery trustee Dr. William Thomas Ross Flemington acted as chairman of the Maritime selection committee and selected individuals to sit on his region's jury. His final committee consisted of Lawren P. Harris (Lawren S. Harris' son) in his capacity as an artist, instructor, and head of Mount Allison University's fine arts program, as well as Donald C. MacKay, principal of the Nova Scotia College of Art, also an arts educator and artist. It was originally suggested as planning began in 1950 that the Maritime Art Association (presumably its executive) should select six works from the region to send 
for jurying at the National Gallery. ${ }^{12}$ Instead, Flemington appointed Harris to his committee. This was unsurprising, since both Harris and Flemington worked at Mount Allison University and Lawren P. Harris came covertly recommended by his father (Lawren S.) who was actively organizing the exhibition. ${ }^{13}$ Saint John artist Miller Brittain was invited to sit on the Maritime selection committee as well but was unable to devote any time to this project due to an upcoming solo exhibition in New York. ${ }^{14}$ Another Saint John artist, Jack Humphrey, was requested to participate on the committee but was making plans to travel to France on a fellowship award (which would significantly redirect the course of his painting) and thus could not act in this capacity. ${ }^{15}$ MacKay - based in Halifax, Atlantic Canada's visual arts hub, and president of the Maritime Art Association - was theoretically able to share extensive knowledge of any work being produced throughout the Atlantic region. Yet he accepted his post as selection committee member with reservations and words of guidance to the Ottawa organizers about provincial representation within the Atlantic Provinces. MacKay warned that, had Brittain been able to accept the National Gallery's invitation, Nova Scotia artists were "very apt to consider that the jury is somewhat over weight in favour of New Brunswick." Marginalia written by Robert H. Hubbard, the Gallery's first curator of Canadian art and who was by 1954 chief curator, responded to this advice by suggesting adding Nova Scotian LeRoy Zwicker to the committee. ${ }^{16}$ Brittain's regrets came as a relief to McCurry, who found it "frankly, difficult to think of another suitable person" in Nova Scotia apart from Zwicker, highlighting the cultural elite's ties to educational institutions and their mutually beneficial knowledge of each other through educational channels. ${ }^{17}$ Other individuals could have been approached, such as painters 
John Cook, Arthur Lloy, Ruth Wainwright, Jack Gray, Joseph Purcell, Douglas Lawley, or Lola Froude Mould.

No one in Prince Edward Island was consulted regarding up-and-coming artists in that province and, originally, no one in Newfoundland was either. The Shepherds (either Reginald or Helen Parsons) in St. John's would have been ideal individuals to consult regarding new talent thanks to their art school's presence there. Having apparently been encouraged by MacKay to think about regional relations and prompted by a letter from trustee Robert Newton, H.O. McCurry decided to include Newfoundland in the selection process if at all possible. Disregarding Newton's suggestion that a culturally aware lawyer friend in Newfoundland act as a National Gallery representative for the exhibition, McCurry instead asked Dr. Flemington to go to St. John's to personally "survey the situation". ${ }^{18}$ In the end, however, Lawren P. Harris made the trip to Newfoundland alone, in Flemington's place, despite claiming "absolutely" no knowledge of its artists. Harris returned with only one work by Reginald Shepherd. ${ }^{19}$

Any regional disparity evident in the biennial series has its roots in the selection of works for Annual Exhibition of Canadian Painting in 1953. Whereas artists in other regions and in the other Atlantic Provinces were subjected to a selection process headed by committees of local art experts, Newfoundland artists were subjected to the opinion of a single, uninformed individual.

McCurry genuinely believed that Newfoundland had been the only province not covered by the original plans for the exhibition, suggesting he believed that art on Prince Edward Island was not worth even investigating. No correspondence between McCurry and Flemington survives wherein any mention is made of selecting art from Prince 
Edward Island. McCurry, in his role as National Gallery director, sought to maintain selection democracy and transparency, necessary principles his federal institution was obliged to follow. Yet, Newfoundland and Prince Edward Island's unique treatment - as afterthought and non-issue, respectively - was a breach of these principles.

Lawren S. Harris devised a precise number of works acceptable from each region, although the jury had difficulty staying within these numerical boundaries. Harris' limitation on the number of works he felt appropriate for a survey exhibition of this sort a maximum of sixty - was challenged during the planning process, but he insisted his figures were arrived at with respect for the limited spatial capabilities of regional galleries to host the exhibition. ${ }^{20}$ Initially, in 1950, he advocated that the Maritimes be represented by no more than six works, Québec by ten or twelve, Toronto (later broadened to Ontario) fifteen, the Prairies ten, and British Columbia twelve to fifteen. ${ }^{21}$ These specific numbers changed slightly as the planning process progressed, and by February 1951 the Maritimes were allotted six, Québec and Ontario seventeen each, the Prairies eight, and British Columbia twelve, reaching his calculated maximum of sixty works.

Harris posited that these quotas additionally reflected the actual number of groundbreaking and significant artists working in the country at the time, many of whom he believed resided in the new province to which he relocated in 1941 - British Columbia. He noted in a letter to McCurry that "what I know of the painting being done in the Maritimes and the prairie provinces would lead me to select as many from B.C. as from the Maritimes and Prairies together - if it is a question of merit". ${ }^{22}$ Although Harris certainly supported artists working in a variety of styles (as his work with the FCA 
indicates), for the purposes of the Annual Exhibition he seemed to equate competency with certain styles.

The "quantity versus quality" debate was a heated one. For selection committees, artists, jurors and audiences alike, this debate pitted trendy movements against traditional art and implied that new, abstract movements were inherently better than representational ones. From the start, Harris and McCurry were at odds over this issue, exemplifying a dynamic which recurred with varying levels of determinacy throughout the history of the biennial series. ${ }^{23}$

Harris supported the qualitative approach to selecting art for the Annual Exhibition and championed the work created in his adopted home province of British Columbia, while McCurry - ever aware of his highly political role - advocated proportional representation from the regions based on population. McCurry tried unsuccessfully to sway Harris from his fervent position and was suspicious of Harris' belief that British Columbia art demonstrated higher "artistic merit" than did the art of most regions. ${ }^{24}$

Until the establishment of the Canada Council in 1957, the National Gallery of Canada was the sole federal entity responsible for exhibiting and otherwise supporting Canadian artists, ${ }^{25}$ many of whom believed the Gallery was obliged to encourage them and take interest in their work. ${ }^{26}$ But over the thirteen years the biennial exhibitions were held, the National Gallery's role as sole supporter of Canadian artists changed. Harris believed the National Gallery should generously assist and support arts development in the regions (as his work with the Federation of Canadian Artists indicated), but his compassion for fellow artists did not encourage inclusion of all the regions in the biennial 
exhibitions. ${ }^{27}$ Harris and McCurry's clashing backgrounds, personalities, and personal histories undoubtedly fuelled this debate. ${ }^{28}$

Another crucial and original component of the 1953 Annual Exhibition (soon to become the biennial exhibition series) envisioned by McCurry and Harris was the concept of touring. Although the Annual Exhibition would open in Ottawa, touring it across the country after an allotted exhibition period at the National Gallery of Canada was believed to be effective on several levels. A tour shared the exhibition with the country's citizens, boosting the Gallery's national significance and the esteem in which artists and the public held it. Touring the exhibition promoted a national standard for artists and art exhibitions, was believed to inspire and educate regional artists who had limited access to major exhibitions of Canadian art, and promoted public awareness about contemporary art. ${ }^{29}$ The decision to tour the Annual Exhibition also responded to recommendations made by the Massey Commission report advocating an increase in the National Gallery’s travelling exhibition services. In light of these benefits, “ $\$ 3000$ or $\$ 1500$ would be well spent by the National Gallery this way." 30

\section{The Biennial is Born}

The Annual Exhibition of Canadian Painting opened in Ottawa on March 10, 1953 and featured seventy-seven works. Well over Harris' sixty-piece limit, the show featured one work completed within the past two years per artist. An accompanying catalogue provided a short biography of each artist, including hometown and education, and black and white reproductions of art select in the exhibition. In general, the pieces chosen roughly reflected the population of each region. However, British Columbia was represented by almost as many works as Ontario and Québec - sixteen for British 
Columbia, eighteen for Ontario, and sixteen for Québec - although its population was one fourth the populations of those provinces. Eleven pieces were drawn from Nova Scotia, New Brunswick and Newfoundland, which compared to the populations of these provinces was substantial representation, thanks in no small part to McCurry's insistence on ensuring representation from all regions. ${ }^{31}$ Similarly substantial representation would not occur in future biennial exhibitions.

The works chosen from Atlantic Canada were by some of the region's most important artists, including the increasingly experimental New Brunswick artists Miller Brittain and Jack Humphrey, figurative painter Fred Ross, along with Norman Eastman of St. Stephen. Lawren P. Harris, although he was part of the regional committee, also exhibited a work - Figure Composition. ${ }^{32}$ Nova Scotia was represented by marine painter Joseph Purcell, landscape painter Anthony Law, Donald C. MacKay, realist Edward Pulford, and LeRoy Zwicker, director of Zwicker's Gallery in Halifax and a largely abstract painter. Reginald Shepherd contributed a watercolour, Hibbs Cove, from Newfoundland. ${ }^{33}$

Shepherd, like Brittain, Humphrey, and many other artists in the region, tended to oscillate between naturalistic and more expressive - almost to the point of abstraction depictions of the natural environment surrounding him. Humphrey's South Wharf with Three Boats, Eastman's Late November, Purcell's Lunenburg, Law's Early Spring, Pulford's Autumn Composition, and Zwicker's Deepwater, Halifax are representational, if not downright mimetic in style. The title for Brittain's gouache painting - And God Made Two Great Lights -features a figure surrounded by abstract shapes and colours; it too is essentially representational. 
The work being produced in Atlantic Canada was not an affront to McCurry's beliefs (nor Eric Brown's before him) on what art should be. It was not suggestive, overly political, theoretical or conceptual. It maintained, predominately, the landscapebased representation which the National Gallery had championed so greatly in the past. Thus, it is not surprising that the region was well-represented in the Annual Exhibition.

While booking tour dates and cities for the Annual Exhibition, McCurry paid particular attention to invite areas which were under-represented in the National Gallery's permanent collection to host the exhibition. Centres such as Winnipeg, Regina, and Edmonton were offered the exhibition for greater time periods than better-represented areas. $^{34}$ Neither Québec nor any of the Atlantic provinces hosted the Annual Exhibition, although it could have travelled there during the four months the exhibition sat dormant after its Ottawa premiere, before it was sent west. Surely Harris believed the Atlantic region would have benefitted most from the "high standard" and "great stimulus" of the touring show. ${ }^{35}$ Due to the exhibition's failure to tour to truly peripheral areas, such as Prince Edward Island or Newfoundland, it is doubtful that excluded artists from these places were affected or encouraged by it.

Later exhibition organizers attempted to excuse McCurry for his regional bias and blamed a scheduling error for a lengthy display time in the Western provinces. Correspondence regarding scheduling indicates, however, that the Maritimes were never considered as hosts for the tour and that significant juggling (and regulation breaching) was done in order to send the exhibition to the prestigious Vancouver Art Gallery two months after the tour's scheduled end. Nearly a quarter of the works chosen for the Annual Exhibition were drawn from Vancouver. ${ }^{36}$ 
During the tour, positive exhibition reviews poured in from host cities, lauding the National Gallery for its support of young Canadian artists. The Gallery basked in the favourable publicity and the board of trustees acquired eight works for its permanent collection. Robert Newton's concerns about Western Canada's under-representation were addressed not only by British Columbia's extra-proportional representation but by purchases; of the eight acquisitions, four works were from British Columbia, three were from Ontario, and one was selected from New Brunswick (Humphrey's South Wharf with Three Boats). ${ }^{37}$

Not all individuals involved in the Annual Exhibition felt it was a resounding success. McCurry, who was frustrated by the selection process and pressured throughout the exhibition planning by the board, Gallery staff, and his responsibilities as the director of a federal institution, felt that a different process for the next show would ease the burden of planning such a mammoth survey. The trustees decided that a biennial program might be the answer to avoiding the pressing administrative woes brought on by organizing, circulating, and acquiring contemporary art from across the country. Lessons gleaned in 1953 indicate that time was a major obstacle to organizing a large, multifaceted, national survey exhibition. Although the Annual Exhibition's selection format had proven successful, both from public relations and acquisitional standpoints, the attention devoted to one exhibition was deemed too great for an already burdened National Gallery staff to face annually. ${ }^{38}$

With an extra year to plan these Canadian surveys, biennial debates occurred among curatorial staff and trustees over the fundamental format and selection methods of the exhibitions themselves. Each successive exhibition introduced a new element or, in 
several instances, underwent a complete overhaul. The series was continually perceived as lacking in some way and as being perpetually improvable.

\section{Exhibition Adjustments}

\section{"If the experiment is not successful, we can always change it."-H.O. McCurry ${ }^{39}$}

Over the thirteen-year span of the biennial exhibitions of Canadian art, various formations of regional selection committees and regional advisors, unofficial and honorary advisors, foreign curators, and juries - under the ultimate control of the National Gallery of Canada director and board of trustees - made decisions with long-term implications. How would works be selected? Who would be appointed as regional committee members or jurors, and why? What kinds of visual art would be selected? How many pieces would be shown? What criteria would signify the "best" in Canadian art? Which artists would be invited to participate? Where would exhibitions tour? Exhibition planners' responses to these questions alternately enraged and appeased artists and influenced public opinion of the National Gallery. ${ }^{40}$ These responses also appreciably reflected the leadership and direction of the National Gallery during these years.

Regional committees continued to suggest work for final selection during the First Biennial Exhibition of Canadian Painting in 1955. The fifth (1963) and sixth (1965) biennial exhibitions used regional advisors in an honorary capacity to assist organizers in locating potentially suitable artists and to direct travelling curators Russell Harper and William Townsend to promising studios. Art in the second (1957), third (1959), and seventh (1968) exhibitions was not chosen with the assistance of experts in the regions, but by National Gallery of Canada regional liaison officers, new professionals at the 
Gallery who were responsible for reaching out to the Atlantic and Prairie provinces. The Fourth Biennial (1961) was an anomaly whereby any and all Canadian artists were invited to submit up to two works for consideration. In all but two instances, the monumental task of final selection was made by juries comprised of Canadian and international art authorities. The sixth and seventh biennials relied on solo external jurors William Townsend (Fine Arts professor at the Slade School at University College in London ) and William Seitz (director of the Rose Art Museum at Brandeis University) respectively - to make their final selections unaided.

The announcement for the First Biennial Exhibition of Canadian Painting, to be held in 1955, stated the series would continue the principles of the annual showings begun in 1926 and use the same selection method as the Annual Exhibition of 1953. These principles included maintaining high selection standards - with only the very best works to be purchased by the Gallery - and soliciting a fixed percentage of paintings based on regional populations. ${ }^{41}$ But the 1955 exhibition announcement included a caveat: special consideration (or leniency with proportional representation) would be given to "several leading art centres in the country". 42

The First Biennial Exhibition of Canadian Painting was organized by McCurry, with later assistance from Hubbard. Five regional committees were appointed to cover British Columbia, the Prairie Provinces, Ontario, Québec, and the Maritimes, with trustees making the final selection. The regional committees were chaired by ex officio trustee members - such as Lawren S. Harris in British Columbia, H. G. Glyde in Alberta, C.P. Fell in Ontario, Jean Chauvin in Québec, and Ross Flemington in the Maritimes. Artists and arts administrators from these regions filled out the remaining seats on the 
committees. In British Columbia B.C. Binning, Charles H. Scott and Doris Shadbolt formed a committee with Harris, while work from the Prairie Provinces was chosen by L.L. FitzGerald, H.G. Glyde, Kenneth Lochhead, and Norah McCullough. Martin Baldwin, Charles Comfort, R.H. Hubbard, A.Y. Jackson and Will Ogilvie chose work from Ontario with C.P. Fell, while Hubbard assisted Arthur Lismer, Jacques de Tonnancour and National Gallery trustees Jean Chauvin and Cleveland Morgan in selecting works in Québec. $^{43}$

LeRoy Zwicker and Jack Humphrey rounded out the Maritime committee (along with Flemington), but not until after some debate. A list of suggested members drawn up on July 7, 1953, indicates that an "outside jury" comprised of Québec art historian Pierre de Ligny Boudreau, painter and former Nova Scotia College of Art principal Arthur Lismer, and Montréal painter and art educator Anne Savage was proposed, overriding initial suggestions for local figures LeRoy Zwicker, Miller Brittain, and Jack Humphrey, and New Brunswick Museum curator Avery Shaw and Donald C. MacKay. A revised version of these suggestions, typed a week later, forcefully disregards the notion of an "outside jury" and settles upon Flemington, Humphrey and Zwicker. ${ }^{44}$ It is curious that an outside jury would be considered. Had the Annual Exhibition's Maritime committee not performed as expected? That seems implausible, since Flemington was again appointed to guide it. Would outsiders contribute to a better understanding of Atlantic Canadian art? In future biennial exhibitions, organizers certainly believed this was the case.

Once again, there was very little attempt by exhibition organizers to concern themselves with Newfoundland and absolutely none regarding Prince Edward Island. No 
individuals from either province were invited to sit on the "Maritime" committee.

Several art groups in the region could have been contacted for input, including the Prince Edward Island Society of Art, the Prince Edward Island Art Association, or the St. John's Art Club. As far as Newfoundland was concerned, Flemington saw no point in "taking any steps to send anybody over there this year" unless McCurry wished. ${ }^{45}$ As an afterthought, Flemington told McCurry he could write Reginald Sheppard and ask him to send a maximum of five paintings in by himself, his wife (Helen Parsons Shepherd), Harold Goodridge, and anyone else who may have risen to prominence in Newfoundland. ${ }^{46}$

Flemington's committee devised a list of thirty-five artists from New Brunswick and Nova Scotia, although he apologetically stated in a letter to McCurry that "a number of them are probably not in the running." ${ }^{47}$ The helmsman's lack of support or faith in the artists of his region is curious.

When the Biennial Exhibition opened on May 18, 1955 in Ottawa, distinct currents in Canadian art could be discerned. Avant-garde artists like B.C. Binning, Roy Kiyooka, Ray Mead, Jack Bush, Kazuo Nakamura, Harold Town, Paul-Emile Borduas, Pierre Gauvreau and Gentile Tondino were represented alongside Nova Scotians Robert Annand and LeRoy Zwicker, New Brunswick artists Lawren P. Harris, Alex Colville, Jack Humphrey, Fred Ross, and Sinclair Healy, and Reginald Shepherd of Newfoundland, most of whom tended toward representational art.

Although only eight paintings from Atlantic Canada were chosen, within the parameters of McCurry's representation-by-population quota model, this number meant that, significantly, 12.9 per cent of all sixty-two works exhibited were from the Atlantic 
region - or more precisely New Brunswick, Newfoundland, and Nova Scotia. Two works, one each, from New Brunswick (Alex Colville) and Nova Scotia (Robert Annand) were purchased out of a total of seventeen nationwide, meaning that 11.7 per cent of purchased works were from Atlantic Canada. ${ }^{48}$ According to 1951 census data, the four Atlantic provinces comprised 11.6 per cent of the country's population; therefore, the Biennial successfully and strictly incorporated the region according to McCurry's quantitative approach.

Reviews provide the descriptions of the exhibition and selected artworks, and are especially useful when installation images are non-existent and works were not reproduced in the catalogues. The Halifax Mail Star discussed Halifax artist and art dealer Zwicker's painting Sea Power as being representative of the ocean and the power behind it, with its "well-designed wave patterns". ${ }^{49}$ Truro artist Robert Annand's predominantly blue-hued, expressive canvas Family Group was characterized as gloomy, but was strongly composed and "sensitively handled" in its portrayal of three generations of a working-class family. ${ }^{50}$ One commenter, "Grateful Viewer", saw in Annand's poignant depiction of a poor and tired family a celebration of strength and love. ${ }^{51}$ Standing Harlequin, a tempera work by Fred Ross demonstrating the Renaissance motifs which so absorbed him in the $1950 \mathrm{~s},{ }^{52}$ did not distinguish itself to critics beyond its strength as an imaginary portrait with beautiful colours and high-quality draftsmanship. ${ }^{53}$

The Leader Post in Regina noted that although Atlantic Canada was well represented, no works from there were outstanding. While Annand was credited with having the most interesting work from the region, Colville's Four Figures on a Wharf was deemed to have the most widespread appeal. ${ }^{54}$ Four Figures does not depict the 
expected local scene of fishermen on a wharf but instead depicts four marble-like, classically posed statuesque figures placed at precise intervals along a white platform jutting out into a carefully rendered body of water, halving the surface and following the horizon. Still, Four Figures demonstrated "chaste simplicity" in the eyes of artist and critic Mildred Valley Thornton in the Vancouver Sun; perhaps a better descriptor would have been austere. ${ }^{55}$ The other works from Atlantic Canada were not described.

In general, painters represented in the First Biennial Exhibition were celebrated for their imagination, originality, and vitality and it was generally agreed that abstract artists were the leaders of Canadian art. As a cross-section of contemporary painting, the First Biennial Exhibition of Canadian Painting presented "the best and the least significant trends" in Canadian art, leading one reviewer from the Ottawa Journal to unflatteringly label the show "Art Like Porridge". 56

The exhibition spent much time touring Nova Scotia and New Brunswick. After its Western tour from September to April 1955 through Regina, Edmonton, Saskatoon, Winnipeg, Vancouver, and Calgary, with a brief stop in Québec, it visited Atlantic Canada. The show was brought to Mount Allison University by the Sackville Art Association in April, and was later brought to the Owens Art Gallery by the School of Fine Arts in August after a brief trip to London, Ontario in June. The Halifax Memorial Library hosted the exhibition in April and May and the Saint John Art Club sponsored its display at the New Brunswick Museum in May and June. ${ }^{57}$ Unfortunately, due to a lack of space in the region's exhibition venues, the Atlantic leg of the travelling show was bereft of so-called "surplus" works (presumably, works either too large or delicate), to the disappointment of Atlantic Canadians who rarely saw exhibitions of this breadth in 
the region. ${ }^{58}$ The exhibition was not hosted in Prince Edward Island or in Newfoundland. Neither province ever saw a travelling biennial exhibition, contrary to the National Gallery's stated desire to see the shows toured "from coast to coast" in response to "everincreasing" demand for travelling exhibitions, even though suitable exhibition space was developed before the series' demise. These included the Confederation Centre Art Gallery (opened in 1964) and the Memorial University Art Centre (established in 1961). ${ }^{59}$

Considering the region's substantial (indeed more than its statistically fair share) representation in the 1955 exhibition, it is unsurprising that few Atlantic Canadians criticized the show or the methods utilized in organizing it. Montréaler and cofounder of the influential Contemporary Arts Society, John Lyman, had been very vocal in his suspicion of selection committee members' appointments in Québec (and the National Gallery's failure to publicize their names), but only Avery Shaw inquired about the committee selection methods as they pertained to Atlantic Canada. ${ }^{60}$ As director of the Art Department of the New Brunswick Museum and the member of the Maritime Art Association (MAA) responsible for bringing the exhibition to the Halifax Memorial Library, Shaw wrote the newly hired National Gallery of Canada director Alan Jarvis (hired in 1955) for an explanation about the committee's selection, surely not only for himself but for many individuals in the MAA. For an upcoming MAA annual general meeting, Shaw required less "vague" details about the exhibition's history, selection criteria, and methods. ${ }^{61}$ Jarvis replied that the procedure used "did not work out in a wholly satisfactory way" and was being changed for the next exhibition. ${ }^{62}$

As Alan Jarvis promised, the Second Biennial Exhibition of Canadian Art (1957) was organized differently. A new method was bound to be employed, not only because 
of the substantial investment of time and energy required to organize and dialogue with committees, but also due to McCurry's retirement in 1955 and his replacement by the young, enigmatic Jarvis.

Jarvis had recently returned to Canada, with the express goal of becoming director of the National Gallery after spending thirteen years in England working in adult education and film, and being involved in social work while maturing as a sculptor. ${ }^{63} \mathrm{He}$ was appointed by Louis St.-Laurent's Liberal government, in part to personify the National Gallery of Canada's changing character: sophisticated, worldly, down-to-earth, and relevant to Canadians. This task was ensured by securing the services of an advertising agency to shape and popularize Jarvis' image. ${ }^{64}$ Germane to the Gallery's attempts to popularize and publicize itself, the handsome, well-spoken, and wellconnected Jarvis was sent on a nation-wide tour in the latter part of 1955 to see and discuss Canadian art. ${ }^{65}$

Jarvis freely shared his views on contemporary art (that it should be moving and push boundaries), which resonated with emerging artists such as Kenneth Lochhead and insulted more conservative patrons who favored the inoffensive "chocolate box" brand of art which Jarvis derided ${ }^{66}$ He also offended a segment of the public who eagerly supported the arts by provocatively saying that Toronto and Montréal art circles consisted of snobs who indulged in art as a social affectation and built galleries for purposes of self-recognition. ${ }^{67}$

Jarvis insisted that Canadian art must be judged by international standards and maintained a dismissive view of art and architecture in the Atlantic and Prairie provinces. ${ }^{68}$ His unsubstantiated comment that he felt "very strongly" a "general poverty 
in the Maritimes of social and cultural life" and his belief that Saint John was one of the world's "ugliest cities... a shanty town in effect" did not bode well for the region's inclusion in the upcoming biennial, or for relations between Atlantic Canadian artists and the National Gallery of Canada. ${ }^{69}$

Organized under the direction of Donald Buchanan, associate director of the National Gallery, the Second Biennial Exhibition of Canadian Art (1957) relied on three advisors from within the institution, two unofficial advisors, and two advisors from abroad to select works in several media that "made their impact in Canada during the post war period" ${ }^{70}$ These works were presented to a jury of three for final selection. JeanRené Ostiguy, the National Gallery's information and extension officer, worked alongside Buchanan and curator Robert Hubbard to select work from artists across the country. ${ }^{71}$ Philip James, the National Gallery's London advisor, and Parisian art dealer Jacques Dubourg sent works to Ottawa from abroad while artists in Italy, Mexico, New York, and Spain were contacted by the Gallery directly. Unofficial, personal advisors (including B.C. Binning and businessman and art collector F.S. Mendel in the West) were appointed by the National Gallery to survey given sections of the country. ${ }^{72}$ Alan Jarvis, Andrew Ritchie (director of the Department of Painting and Sculpture at the Museum of Modern Art, New York), and Jean Simard (art critic and instructor at Montréal's École des Beaux-Arts) were the jurors.

Lawren P. Harris began coaching Jarvis as early as February 1956 on the methods he felt best for the biennials, including the number of pieces to include from each region, potential jury members and painters in British Columbia, the type of work to include, the amount of art to acquire, and the payment of rental fees and prize monies to participating 
artists. ${ }^{73}$ Although he agreed that a large exhibition featuring first-rate art of all media as envisioned by Jarvis would be a "good idea as a big "buying show", Harris counseled Jarvis against such a concept for several reasons. Harris rightly noted that this format would hinder smaller regional galleries' ability to host the biennial exhibition when it toured, and warned that the high standard Jarvis sought would never work for a national survey exhibition. Harris believed that,

It is inevitable that the best work, say from the Prairie Provinces, will not be as good as that say from Québec. No matter what improvements in standards occur the work of one province or region will be better than the others and yet all parts of the country should be represented in a National biennial.

Harris believed that such lopsided excellence was less visible in provincial or regional survey exhibitions and suggested that the volume and media of work for the exhibition be carefully thought through to avoid this pitfall. ${ }^{74}$

Artists were approached by invitation and those selected had the option of sending more than one work to the jury, including drawings, prints, and sculpture (although no sculptures were selected from the few that were submitted). ${ }^{75}$ Some artists were flattered by invitations to submit works for exhibition but an invitation did not necessarily mean works would be chosen by the jury. ${ }^{76}$

Jean-René Ostiguy, a rising art scholar and the National Gallery's first bilingual staff member (he was the public relations officer), ${ }^{77}$ was solely responsible for the overwhelming task of selecting art in the Atlantic Provinces and Québec. Ostiguy visited Robert Annand in Truro, Ruth Wainwright and LeRoy Zwicker in Halifax, Alex Colville and Lawren P. Harris in Sackville, Jack Humphrey, Fred Ross, Julia Crawford, and Miller Brittain in Saint John, and Bruno Bobak in Fredericton, during the autumn of 1956. ${ }^{78}$ Buchanan toured studios in the Prairie Provinces and British Columbia and 
Hubbard had the less onerous task of selecting work from Ontario artists, mainly in Toronto.

A cumbersome total of four hundred artworks from one hundred eighty-three artists were sent to Ottawa for consideration. The jury chose forty-five oil paintings and thirty-two drawings and prints for the Second Biennial Exhibition of Canadian Art, sixteen from British Columbia, eleven from the Prairie Provinces, sixteen from Ontario, and thirty from Québec. ${ }^{79}$ Out of the twenty-five works Ostiguy submitted to the jury from Atlantic Canada, four pieces were chosen: one by Wainwright (the charcoal drawing Skeleton Structure), two by Colville (an oil on masonite painting, Woman at Clothes Line, and the serigraph Cat on Fence), and one by Humphrey (the watercolour From Perry Point). ${ }^{80}$ While the total number of works for this exhibition increased from the 1953 annual and first biennial (1955) exhibitions, Atlantic artists' representation dropped from a proportional 12.9 per cent in the First Biennial Exhibition of Canadian Painting to 5.2 per cent in the Second. However, the precise and cool-hued Woman at Clothes Line, the prowling Cat on Fence, and the energetic, gestural From Perry Point were among thirty-four works purchased by the Gallery, and the Atlantic Provinces accounted for 8.8 per cent of purchases made from the exhibition by the National Gallery. The region never saw the exhibition, though, as it travelled the country.

Works rejected by biennial juries were occasionally offered to the Department of External Affairs for possible purchase, relieving the Gallery from returning them and providing the Department of External Affairs and Canadian embassies with original Canadian art. In some cases, these pieces were privately purchased by Buchanan and his associates. ${ }^{81}$ The blow of rejection was softened for Atlantic Canadian artists by the 
potential inclusion of their rejected work in a future exhibition, Some Artists from the Maritime Provinces, being planned by Ostiguy for $1960 .^{82}$

\section{A Biennial for Canada or a Canadian Biennial for the World?}

The Second Biennial Exhibition of Canadian Art opened in Ottawa in April 1957 and was circulated to all provinces but New Brunswick, Nova Scotia, Prince Edward Island, and Newfoundland. Donald Buchanan's introduction in the catalogue set an international tone for the show. Buchanan noted that the exhibition demonstrated Canadian artists' "full acceptance of the whole western world as their cultural home. The best of Canadian work is now being merged in the universality of art."83 He identified changing focal points in Canadian art: namely, fading regional characteristics, vanishing naturalism and realism ("even in their decorative or romantic variations, [naturalism and realism] are no longer the favourite paths to creation among Canadian artists") ${ }^{84}$ and exponential growth in abstraction.

In the field of abstraction, however, Buchanan identified only a handful of successful practitioners. Only noteworthy abstract painters such as Paul-Émile Borduas, Jean Paul Riopelle, and William Ronald were included in the exhibition. He denounced the other abstractionists as fleeting "non-flowering grasses and stalks of art", shooting up quickly and dying as suddenly "to form the compost heap from which the more powerful growths are fertilized." 85

Buchanan cited the disappearance of regional characteristics, yet immediately identified regional distinctions between French and English artists in Montréal and Toronto through their paint handling, and singled out Colville's "romantic realism", linking what he had previously judged to be a vanishing style with the Atlantic region. ${ }^{86}$ 
The National Gallery's attempt to cultivate and project an international image by linking Canadian abstraction with international abstract art movements, while simultaneously surveying the actual state of Canadian art in the two years since 1955, made reconciling various styles in one exhibit difficult. This is evident in the merit awards given at the show. Alex Colville (whose acute realism seems an uneasy fit with these abstractionists) is nestled amidst Paul-Émile Borduas, Jean Paul Riopelle, William Ronald, Jacques de Tonnancour, Harold Town, Léon Bellefleur and Albert Dumouchel. Of all the merit award winners, Jean Paul Lemieux's style was closest to Colville's, although their production differs greatly. Lemieux's "delicate technique" and stiff, arrested figures in his 1950s work demonstrate an overlapping interest in the figure but his works lack the arresting coolness and high realism of Colville's work. Should Colville's work demonstrate an international link, it would be with American realism, not the Abstract Expressionism and other international abstract movements so championed at that time.

A scathing letter from nineteen Québec artists, self-identifying as the "compost" of abstraction, accused the jury of incompetence, calling the final selection process a game of compromises, partisanship, and favoritism which omitted many young abstract artists' work. Signed by painters Louis Belzile and Fernand Toupin (representatives of the Plasticiens), Paterson Ewen, André Jasmin, Fernand Leduc, Rita Letendre, Jean McEwen, and Jean-Paul Mousseau (associated with the Non-figurative Artists' Association of Montréal), and co-signed by fellow artists including Ulysse Comtois, Marcelle Maltais, and Guido Molinari, this document displays the confidence painters in Montréal had in their work and their desire to make their displeasure known. ${ }^{87}$ 
There was no such publicized anger, though, from Atlantic Canadian artists regarding Jarvis' disdainful comments on the region or their under-representation by the biennial jury. Unlike the Québec artists above, Atlantic artists seemed to take no offense when, based on the region's limited representation - not its content in the Second Biennial Exhibition -, art critic Robert Ayre declared the Maritimes to be lagging behind strong artistic centres in Québec, Ontario, and Vancouver. ${ }^{88}$ Although the work of Annand, Humphrey, Ross, Zwicker and other rejected artists was not completely abstract, their expressions were no less reflective of the times in which they were made and no more derivative than works adhering to the "One-World [style] of modern art ([or] the Paris and New York studios)" ${ }^{89}$ The Halifax Chronicle-Herald and Mail Star ran an article and editorial, respectfully, in response to Jarvis' comments on the Atlantic Canada's cultural poverty. Both denounced him and noted that Maritimers' faith in directors of national institutions had been shaken by his proclamation. No articles, however, discussed Atlantic representation at the biennial exhibition.

In addition to Jarvis' desire for Canadian art to meet international standards, American curator Andrew Ritchie's place on the jury, and Buchanan's outward-looking catalogue essay, the National Gallery demonstrated its burgeoning desire to become part of the international art scene by sending selected works from the Second Biennial Exhibition of Canadian Art to the Canadian Pavilion at the Universal and International Exhibition held in Brussels from April to October 1958. ${ }^{90}$

In only four years (from 1953 to 1957), the biennial series was established as a significant event in Canada's cultural life. The exhibitions (and their organization) proved to be controversial among artists and the public alike. Each exhibition would 
showcase the results of experiments into the best ways to select Canadian art. ${ }^{91}$ It was, thus far, not necessarily the modifications to the selection methods or lack of touring that led to uneasiness with the series in Atlantic Canada. Instead, the characterization of the region's art in exhibition catalogues (which segregated it from work done elsewhere in the country) and insulting comments from Alan Jarvis led to tension between the region and National Gallery. This uneasiness was not openly communicated by artists to the Gallery, but this bitterness would ripen as the biennial series continued to extend its reach into the international art world. 
Endnotes

${ }^{1}$ Nathalie Limbos-Bomberg, "The Ideal and the Pragmatic: The National Gallery of Canada's Biennial Exhibitions of Canadian Art -1953-1968" (master's thesis, Carleton University, 2000), 37-38.

${ }^{2}$ Paul Litt, The Muses, The Masses, and the Massy Commission (Toronto: University of Toronto Press, 1992), 186.

${ }^{3}$ Douglas Ord, The National Gallery of Canada: Ideas, Art, Architecture (Montréal and Kingston: McGillQueen's University Press, 2003), 123.

${ }^{4}$ Letter from Harris to Unknown, November 1950, Annual Exhibition of Canadian Painting 1953, File 1, NGA.

${ }^{5}$ The use of the term "Maritime" is erroneous here, as it excludes the new province Newfoundland. The term "Atlantic" Canada would reflect the inclusion of this province. Harris to Comfort, 30 January 1951, Annual Exhibition of Canadian Painting 1953, File 1, NGA.

${ }^{6}$ Annual Exhibition of Canadian Painting 1953, File 1, NGA.

${ }^{7}$ Board of Trustees: Minutes of Meetings, File 9.2-B, 517-518, NGA.

${ }^{8}$ Ibid.

${ }^{9}$ Letter from McCurry to Flemington, 12 December 1952, Annual Exhibition of Canadian Painting 1953, File 1, NGA.

${ }^{10}$ Annual Exhibition of Canadian Art 1953, File 1, NGA.

${ }^{11}$ Letter from McCurry to Flemington, 12 December 1952, Annual Exhibition of Canadian Painting 1953, File 1, NGA.

${ }^{12}$ Excerpt from letter from Lawren S. Harris to unknown (presumably McCurry), 1 December 1950, Annual Exhibition of Canadian Painting 1953, File 1, NGA.

${ }^{13}$ Harris to McCurry, 10 December 1951, Annual Exhibition of Canadian Painting 1953, File 1, NGA.

${ }^{14}$ Letter from Brittain to Hubbard, 3 December 1952, Annual Exhibition of Canadian Painting 1953, File 1, NGA.

${ }^{15}$ Letter from Lawren P. Harris to unknown (presumably McCurry), n.d., Annual Exhibition of Canadian Painting 1953, File 1, NGA. See also Russell Harper, Jack Humphrey: A Painter in the Maritimes (Fredericton: Beaverbrook Art Gallery, between 1970-1976), 13.

${ }^{16}$ Annual Executive Report for Year Ending December 31, 1951, MG.20 vol. 208, NSMFA Book Volume III, NSARM. Letter from D.C. MacKay to McCurry, 5 December 1952, Annual Exhibition of Canadian Painting 1953, File 1, NGA.

${ }^{17}$ Letter from McCurry to Flemington, 12 December 1952, Annual Exhibition of Canadian Painting 1953, File 1, NGA. Paul Litt, The Muses, the Masses, and the Massey Commission (Toronto: University of Toronto Press, 1992), 52 \& 147.

${ }^{18}$ Letter from Newton to McCurry, 11 December 1951, Annual Exhibition of Canadian Painting 1953, File 1, NGA. Letter from McCurry to Flemington, 12 December 1952, Annual Exhibition of Canadian Painting 1953, File 1, NGA.

${ }^{19} \mathrm{He}$ claimed to know "absolutely nothing whatsoever." L. Harris to H.O. McCurry, 5 March 1951, Annual Exhibition of Canadian Painting 1953, File 1, NGA.

${ }^{20}$ Excerpt from letter from Lawren Harris (presumably to McCurry), 11 February 1951, Annual Exhibition of Canadian Painting 1953, File 1, NGA.

${ }^{21}$ Letter from Harris to unknown (presumably McCurry), 1 December 1950, Annual Exhibition of Canadian Painting 1953, File 1, NGA.

${ }^{22}$ Letter from Harris to McCurry, 10 December 1951, Annual Exhibition of Canadian Painting 1953, File 1, NGA.

${ }^{23}$ Letters exchanged between McCurry and Newton which refer to Harris' determination to avoid representation by population demonstrate how frustrating a matter this was in planning the exhibition. See Annual Exhibition of Canadian Painting 1953, File 1, NGA.

${ }^{24}$ Letter from McCurry to Newton, 13 December 1951, Annual Exhibition of Canadian Painting 1953, File $1, \mathrm{NGA}$

${ }^{25}$ See "Carot Interviews Jean Sutherland Boggs", Carot 2, no. 4 (Summer 1976): 8. 
${ }^{26}$ Members of the NSMFA believed that the National Gallery should take an interest in art across the country but that the provinces would benefit more from provincially-generated interest. NSMFA Minutes, 7 December 1949, MG.20 vol. 208, NSMFA Book Volume III, NSARM.

${ }^{27}$ Lawren Harris, "Community Art Centres - A Growing Movement," Canadian Art 2, no. 2 (December 1944 - January 1945): 63. Limbos-Bomberg, 43.

${ }^{28}$ McCurry's began as a civil servant who classified trade statistics with the Customs Department before moving to the Gallery in to oversee accounts for the Department of Public Works. There, he became a close friend and eventually assistant and successor to Eric Brown. As a follower of Brown's aesthetic opinions for a time (although he came to appreciate and actively collect Modern European works), and a Christian Scientist, McCurry surely clashed with Harris and his background as painter, activist, a Theosophist. In any case, both rallied for the National Gallery and Canadian artists' best interests. See Ord's chapter "Brown, 'National Spirit,' and 'Futurism'" for more context and discussion. Ord, 75-99, pages 96 to 98 for specific material on McCurry. See also Peter Larisey, Light for a Cold Land: Lawren Harris' Work and Life - An Interpretation (Toronto: Dundurn Press, 1993) for more information on Harris. ${ }^{29}$ Excerpt from letter from Lawren S. Harris to unknown (presumably McCurry), 1 December 1950, Annual Exhibition of Canadian Painting 1953, File 1, NGA.

${ }^{30}$ Quote from Massey Commission Report is found in Limbos-Bomberg, 59. Also Excerpt from letter from Lawren S. Harris to unknown (presumably McCurry), 1 December 1950, Annual Exhibition of Canadian Painting 1953, File 1, NGA.

${ }^{31}$ See Appendix I: Regional Representation for the Annual Exhibition of Canadian Painting in LimbosBomberg, 171.

${ }^{32}$ Robert Newton opposed artists being on committees. It is surprising that artists on committees could have their work selected for submission to the jury. See Newton to McCurry, 11 December 1951, Annual Exhibition of Canadian Painting 1953, File 1, NGA.

${ }^{33}$ Annual Exhibition of Canadian Painting 1953, Exhibition Catalogue (Ottawa: National Gallery of Canada, 1953), Annual Exhibition of Canadian Painting 1953, Vol. 3, Box 174, File 2, NGA.

${ }^{34}$ Limbos-Bomberg, 60-61.

${ }^{35}$ Excerpt from letter from Lawren S. Harris to unknown (presumably McCurry), 1 December 1950, Annual Exhibition of Canadian Painting 1953, File 1, NGA.

${ }^{36}$ Letter from McCurry to Sydney Key, 7 May 1953, Annual Exhibition of Canadian Painting 1953, File 2.

${ }^{37}$ See Annual Exhibition of Canadian Painting 1953 Doc files, NGA, and Limbos-Bomberg, 63-64.

${ }^{38}$ Limbos-Bomberg, 64.

${ }^{39}$ Letter from McCurry to Harris, 13 December 1951, Annual Exhibition of Canadian Painting 1953, File 1, NGA.

${ }^{40}$ John Lyman vocalized his disapproval of the selection process and aims of the series as early as the First Biennial and represents many of his colleagues. Letter from Lyman to Hubbard, 30 June 1955, First Biennial Exhibition of Canadian Painting, File 2, NGA. Ontario artist Frank Panabaker told Charles Comfort the Biennial program should be dropped as he believed the Fourth was a "sheer waste of good public money". 8 August 1962, 12-4-154, vol. 1, The Fifth Biennial Exhibition of Canadian Painting, NGA. Jack Humphrey labeled the Fourth and Fifth Biennial Exhibitions as "unsearching", "inadequate" and "remarkably unsatisfactory". Letter from Humphrey to Hubbard, 26 November 1964, 12-4-227, vol. 3 , The Sixth Biennial Exhibition of Canadian Painting, NGA. See biennial exhibition documentation files for newspaper clippings that praise the exhibitions.

${ }^{41}$ Exactly what the very best work consists of or looks like is not stated or clarified by exhibition organizers.

${ }^{42}$ Announcement of Biennial Exhibition of Canadian Painting, 1955, First Biennial Exhibition of Canadian Painting, File 1, NGA.

43 "Biennial Exhibition of Canadian Painting: Selection Committees (suggested)," 14 July 1953, First Biennial Exhibition of Canadian Painting, File 1, NGC.

${ }^{44}$ Selection Committees (Suggested), 7 July 1953 and 14 July 1953, First Biennial Exhibition of Canadian Painting, File 1, NGA.

${ }^{45}$ Dr. Flemington to H.O. McCurry, 14 July 1954, First Biennial Exhibition of Canadian Painting, File 1, NGA .

${ }^{46}$ Ibid. 
${ }^{47}$ Ibid.

${ }^{48}$ This figure contradicts Limbos-Bomberg's figure of 11.2 per cent. She apparently did not include Sinclair Healy in her calculation of works included by Atlantic artists in the first biennial exhibition. A memo circulated in 1954 to the Ontario selection committee indicates that purchases were to be a "minor consideration". Instead, the goal would be to keep the Gallery in touch with current developments in Canadian art. Memo to Meeting of the National Gallery Ontario Committee for the Canadian Biennial Exhibition, 17 March 1954, First Biennial Exhibition of Canadian Painting, File 1, NGA.

${ }^{49}$ Halifax Mail Star, "Canadian Art Exhibition Now Open," 30 April 1956, First Biennial Exhibition of Canadian Painting, File 3, NGA.

${ }^{50}$ Ibid.

${ }^{51}$ Halifax Mail Star, "Letters to the Editor: Above the Commonplace", 11 May 1956, First Biennial Exhibition of Canadian Painting, File 3, NGA.

${ }^{52}$ See Tom Smart, The Art of Fred Ross: A Timeless Humanism (Fredericton: Goose Lane Editions and The Beaverbrook Art Gallery, 1993), 46-49.

${ }^{53}$ Halifax Mail Star, "Canadian Art Exhibition Now Open," 30 April 1956, First Biennial Exhibition of Canadian Painting, Doc files, NGA.

${ }^{54}$ R.B.S., "Display of Canadian Painting at Gallery," The Leader Post (Regina, Saskatchewan), 13 May 1954, First Biennial Exhibition of Canadian Painting, Doc files, NGA.

${ }^{55}$ Mildred Valley Thornton, "National Art Show Arrives in City," Vancouver Sun, December 1955, First Biennial Exhibition of Canadian Painting, Doc files, NGA.

${ }^{56}$ R.B.S., "Display of Canadian Painting at Gallery," The Leader Post (Regina, Saskatchewan), 13 May 1954. Shirley Gillespie, "Art Like Porridge: Canadian Paintings at National Gallery 'Full of Vitality", The Ottawa Journal (19 May 1955), First Biennial Exhibition of Canadian Painting, Doc files, NGA.

${ }^{57}$ First Biennial Exhibition of Canadian Painting 1955 Itinerary, First Biennial Exhibition of Canadian Painting, File 1, NGA.

${ }^{58}$ Halifax Mail Star, "Canadian Art Exhibition Now Open". See also letter from McCurry to Flemington, 28 April 1955, First Biennial Exhibition of Canadian Painting, File 2, NGA.

${ }^{59}$ Canadian Press Dispatch, "The National Gallery Announces First Biennial Exhibition", First Biennial Exhibition of Canadian Painting, File 3, NGA. See correspondence between NGC and PEISA in Letter from Laura A. Master to Mrs. Henderson, 15 August 1955, First Biennial Exhibition of Canadian Painting, File 3, NGA.

${ }^{60}$ Lyman was most likely upset about artists excluded by the Québec selection committee as well. Letter from Lyman to Hubbard, 30 June 1955, First Biennial Exhibition of Canadian Painting, File 2, NGA.

${ }^{61}$ Letter from Shaw to Alan Jarvis, 3 May 1956, First Biennial Exhibition of Canadian Painting, File 3. Shaw to Jarvis, 24 May 1956, First Biennial Exhibition of Canadian Painting, File 3, NGA.

${ }^{62}$ Letter from Jarvis to Shaw, 30 May 1956, First Biennial Exhibition of Canadian Painting, File 3, NGA.

${ }^{63}$ For a detailed biography of Alan Jarvis see Andrew Horrall, Bringing Art to Life: A Biography of Alan Jarvis (Montréal and Kingston: McGill-Queen's University Press, 2009).

${ }^{64}$ Ibid., 242.

${ }^{65}$ Ibid., 249-251.

${ }^{66}$ Robert McKeown (interviewer), "Is Art Necessary?" Weekend Magazine, vol. 6, no. 20 (19 May 1956): 2.

${ }^{67}$ Ibid.:4.

${ }^{68}$ Horrall, 252.

${ }^{69}$ See quote and comments from the Weekend interview in MAA Reports and Minutes of the Annual Meeting 1955-56, Amherst, 31 May 31 - 1 June 1956, Vol. 501, File 6, NSARM.

${ }^{70}$ Typewritten letter, "Canadian Biennial Exhibition, National Gallery of Canada 1957", no sender or recipients listed, Second Biennial Exhibition of Canadian Art, File 1, NGA.

${ }^{71}$ Buchanan to Jarvis, Hubbard, Fenwick and Ostiguy, 1 November 1956, Second Biennial Exhibition of Canadian Art, File 1, NGA.

${ }^{72}$ Buchanan sent confidential letters to Binning and Mendel requesting advice on new talents he should visit during his westward studio tour. Letters from Buchanan to Binning and Mendel, 2 November 1956, Second Biennial Exhibition of Canadian Art File 1, NGA.

${ }^{73}$ Harris to Jarvis, 5 February 1955, 30 May 1955, 13 June 1955, 21 June 1955, Second Biennial Exhibition of Canadian Art, File 1, NGA. 
${ }^{74}$ Harris to Jarvis, 21 June 1955, Second Biennial Exhibition of Canadian Art 1957, File 1, NGA.

${ }^{75}$ Second Biennial Exhibition of Canadian Art, File 1, NGA.

${ }^{76}$ Ruth Wainwright congratulates Ostiguy on the "excellent" new selection procedure and notes that it is "certainly ideal for the artists... what more could one ask?!!" Letter from Wainwright to Ostiguy, 4 February 1957, Second Biennial Exhibition of Canadian Art, File2, NGA.

${ }^{77}$ Ostiguy had a fairly illustrious career before working for the National Gallery of Canada. He was a former art critic for Le Devoir and professor of Basic Design and History of Art at the Ecole des BeauxArts in Montréal and Professor of Art Appreciation in Valleyfield, Québec schools. A.L. Tunnell, Canadian Who's Who: 1958-1960, Volume VIII (Toronto: University of Toronto Press, 1960), 853. Horrall notes that Ostiguy was the first bilingual NGC staff member, 247.

${ }^{78}$ See Second Biennial Exhibition of Canadian Art, File 1, NGA for information on Ostiguy's travels through Atlantic Canada.

${ }^{79}$ Donald W. Buchanan, "Introduction", Second Biennial Exhibition of Canadian Art (Ottawa: National Gallery of Canada, 1957), 1.

${ }^{80}$ The figure "twenty-five" was arrived at by totaling paintings and drawings listed in letters and inward shipment records. See Second Biennial Exhibition of Canadian Art, File 1, NGA. Limbos-Bomberg's history of the exhibitions notes the inclusion of a Newfoundland artist in her Appendix. I can find no record of a Newfoundland artist included in this exhibition. She also indicates that two works from Nova Scotia were purchased from this exhibition, but in fact none from that province were. See Second Biennial Exhibition of Canadian Art 1957, File 3, NGA for records of Atlantic Canadian purchases.

${ }^{81}$ Letters from Buchanan to Tanabe, Samuals, Jensen and Bobak, 10 April 1957, Second Biennial Exhibition of Canadian Art, File 3, NGA.

${ }^{82}$ Rejection letters to Atlantic Canadian artists may be found in Second Biennial Exhibition of Canadian Art, File 3, NGA.

${ }^{83}$ Donald W. Buchanan, "Introduction", Second Biennial Exhibition of Canadian Art 1957 (Ottawa: National Gallery of Canada, 1957), 1.

${ }^{84}$ Ibid., 2.

${ }^{85}$ Ibid.

${ }^{86} \mathrm{Ibid}$.

${ }^{87}$ Letter from Fernand Leduc [initials appear to be F.L.] to Jarvis, 24 May 1957, Second Biennial Exhibition of Canadian Art, File 4, NGA.

${ }^{88}$ Donald W. Buchanan and Robert Ayre, "The Second Biennial of Canadian Art", Canadian Art 14, no. 4 (Summer 1957): 148.

${ }^{89}$ Carl Weiselberger, "Most Younger Artists Using Abstract Theme," Ottawa Citizen (4 April 1957), Second Biennial Exhibition of Canadian Art 1957 DOC file, NGA.

${ }^{90}$ Letter from Buchanan to Claude Picher, 13 February 1958, Second Biennial Exhibition of Canadian Art File 5, NGA. For more on Canada's preparations for Brussels see Donald Buchanan "Best Food Forward in Brussels," Canadian Art 14, no. 2 (Winter 1957): 64-67.

${ }^{91}$ Each exhibition catalogue contains in its foreword at least one sentence referring to the experimental nature of the selection methods used. 


\section{Chapter 3}

\section{Experimentation, Regional Tension,}

and the Demise of the Biennial Exhibitions of Canadian Art (1959-1968)

This chapter continues examining Atlantic Canadian inclusion in the biennial exhibitions of Canadian art from 1959 to the series' demise in 1968. During this later period, the exhibitions grew in size and the selection processes were altered for each. Modifications to the selection process (some as drastic as the fourth biennial's open submission call in 1961 ) and changes in touring (which reached an international peak when the Fifth Biennial Exhibition was opened in London in 1963) were devised in order to reach out to certain pockets of the Canadian art community. Little known artists welcomed the open submission call as a chance to become known; while many acclaimed artists balked at such a process. Established artists criticized the relentless jurying that occurred throughout the series and some eventually declined to participate. Difficult economic times for Canada during the 1960s forced the National Gallery to examine the value provided by these modifications. The open submission call resulted in a very expensive exercise in democratic selection, leading the Gallery, unsurprisingly, to use streamlined and cost effective juries of one for the last two biennial exhibitions in 1965 and 1968.

With these changes, the National Gallery attempted to please the public, established artists, and the federal government, but the biennial exhibitions increasingly alienated different Gallery constituents. Although Atlantic Canadian artists were initially well-represented in the series, their inclusion in the exhibitions steadily diminished, their relationship with the National Gallery was at times strained, and the characterization of 
the region's art (particularly during the Fifth Biennial Exhibition's 1963 London tour) grew increasingly unfavourable. Following Clement Greenberg's influential visit to the Emma Lake Artists' Workshop in 1962 and his championing of Prairie artists for the remainder of the decade, the Atlantic region became even less attractive to biennial exhibition organizers seeking international approval. ${ }^{1}$ As the biennial period ended, though, a transformation occurred that would see the Atlantic region become an hotbed of avant-garde activity. But for the duration of the biennial exhibitions, the Atlantic region and Atlantic artists were often left behind.

\section{Reaching Out to the Atlantic Region}

By 1959, Jean-René Ostiguy, previously the National Gallery's information and extension officer, had been promoted to education director at the Gallery and subsequently became exhibition organizer for the Third Biennial Exhibition of Canadian Art. Once again, artists demonstrating progress and high standards ${ }^{2}$ were invited by invitation to submit works for final selection by a jury of three, including Gordon Washburn from the Carnegie Institute (1959's “distinguished American” juror), ${ }^{3}$ Colin Graham, curator at the Art Gallery of Greater Victoria, and the National Gallery's Donald Buchanan.

The National Gallery appointed regional liaison officers in 1958 to reach out to peripheral regions and maintain contact and dialogue with them, an adaptation of the 1944 Federation of Canadian Artists' recommendation to split the National Gallery into satellite branches. ${ }^{4}$ Norah McCullough had been the executive secretary of the Saskatchewan Arts Board and had previously advised the National Gallery on artists in the region before becoming the National Gallery of Canada's Western liaison officer. 
Claude Picher, artist, art historian, and former director of exhibitions at the Musée de la Province in Québec City, became the Eastern liaison officer and was responsible for outreach to the four Atlantic provinces as well as Québec. ${ }^{5}$

For the Third Biennial Exhibition of Canadian Art, McCullough and Picher were responsible for identifying artists in their areas who should be invited to submit works. The liaison officers were also encouraged to seek the advice of art gallery and museum directors at the Vancouver Art Gallery, the Edmonton Museum of Art, the Norman MacKenzie Art Gallery, Regina College, the Winnipeg Art Gallery, the Art Gallery of Toronto, Montréal's École des beaux-arts, Québec City’s Musée de la Province, and the Nova Scotia College of Art. This consultation was to identify potential artists to invite, and to ensure that art would be accumulated and housed in those locations for McCullough and Picher's inspection. ${ }^{6}$

Picher, along with Richard Simmins, director of exhibitions, Extension Services at the National Gallery of Canada, travelled in February 1958 to Sackville, New Brunswick, to attend the annual meeting of the Maritime Art Association, assess exhibition facilities in the region for the purposes of tailoring travelling exhibitions for the Atlantic circuit, meet with artists and arts administrators in the region, and explain the extension services offered by the National Gallery. ${ }^{7}$ After Jarvis' injurious comments about Atlantic Canada two years earlier, it appeared that the region was poised to make a fresh start with the National Gallery; Extension Services was working with the Maritime Art Association, striving to understand the state of Atlantic Canadian art, service the region's exhibition and art education needs, and consider its infrastructure limitations. When selecting art for the Third Biennial Exhibition during March 1959, though, Picher 
noted in a telegram to Ostiguy that there was "hard driving here and much bitterness". Was Picher referring to the weather or to the artists he encountered?

From Atlantic Canada, Alex Colville, Lawren P. Harris, Jack Humphrey, Fred Ross, Ruth Wainwright, LeRoy Zwicker, and Robert Annand were initially invited to submit works to the Third Biennial, ${ }^{9}$ but exhibition entry form records suggest that Picher looked carefully at Nova Scotia and New Brunswick artists during his busy survey and invited many more to participate. From New Brunswick, painter Dorothy Sleep submitted three works and Miller Brittain four. Nova Scotia painters Gerald Roach, Aileen Meagher, John Cook, and the then-recently-transplanted Dalhousie University librarian Douglas Lochhead (Kenneth Lochhead's brother, who had ties to the province through his mother and his Sydney-born wife ${ }^{10}$ each submitted three works. ${ }^{11}$ Newfoundland remained a befuddling province for exhibition organizers who did not know who to ask for assistance in choosing artists there. ${ }^{12}$ Reginald Shepherd once again submitted works to the jury, the lone artist representing Newfoundland. In total, Picher selected an impressive sixty works from the region. ${ }^{13}$

Surprisingly, of those works, Washburn, Graham, and Buchanan selected only four (Colville's Hound in a Field and Couple on a Beach, Humphrey's Fanciful Structure, and Ruth Wainwright's Coal Pier). ${ }^{14}$ Approximately seven hundred pieces were sent to the National Gallery from across the country as well as from France, Switzerland, Italy, the United States, and the United Kingdom; ninety-eight pieces in total were selected by the jury. ${ }^{15}$ As in the Annual Exhibition, eight works were purchased for the permanent collection, two of which were by Colville. A 
disproportionate 25 per cent of purchases from the exhibition were from the Atlantic provinces. ${ }^{16}$

Following its summer showing in Ottawa, the Third Biennial Exhibition toured British Columbia, Alberta, Saskatchewan, Ontario and Québec. It spent twenty-two days in New Brunswick at the Beaverbrook Art Gallery in Fredericton. Much to the shock and disappointment of members of the Sackville Art Association (SAA), who tried for months to rent the exhibition for display in the Owens Art Gallery, the National Gallery would not allow them to borrow the show. Upon seeking an explanation, R. A. Boorne, director of the SAA, was notified by Richard Simmins that "exhibitions of this sort rarely can be offered to centres like Sackville. The Biennial is booked only in the major cities in Canada."17 This explanation fails to account for the previous loan of the First Biennial Exhibition of Canadian Painting and for the myriad travelling exhibitions sent to Mount Allison University on a regular basis, as Boorne pointed out in a dismayed response. ${ }^{18}$ In addition, Fredericton had not become one of Canada's major cities (even if it was the provincial capital), but its new art gallery (specifically its well-known Europe-affiliated benefactor and namesake) was significant enough to host an increasingly "famous" exhibition. ${ }^{19}$

At the May 2, 1960 opening of the Third Biennial Exhibition at the Beaverbrook Art Gallery, the National Gallery's board of trustees chairman, Thomas Maher, promised "a gigantic step in art in the Atlantic provinces" due to the upcoming exhibition of Maritime Artists. Ostiguy had been planning the aptly titled Some Maritime Artists and hoped to circulate it under the auspices of the National Gallery from September 1960 to June $1961 .^{20}$ This special regional exhibition had been in development as early as 1957, 
when Lawren P. Harris heard rumours that the National Gallery was planning a Maritime exhibition. Harris had been concerned that such a show which would overlap with a similar one planned for Mount Allison University. ${ }^{21}$ The National Gallery 's survey exhibition of Maritime artists would not occur for several years, with major issues intervening between the planned autumn 1960 opening of Some Maritime Painters (most conspicuously its 1960 cancellation) and the opening of the smaller, replacement version organized a year later by Simmins, entitled Six East Coast Painters. Rather than foster good relations or mutual respect between Ottawa and Atlantic Canada, planning these exhibitions brought to the fore underlying and previously unarticulated tensions that existed between Atlantic Canadian artists and the National Gallery of Canada.

Claude Picher was tasked with selecting art for Some Maritime Painters during his spring 1960 speaking tour in the region. He selected twenty-five painters in addition to those "known to a certain extent" by the National Gallery, such as Jack Humphrey, Fred Ross, Miller Brittain, Alex Colville, Lawren P. Harris, Edward Pulford, Robert Annand, Ruth Wainwright, and LeRoy Zwicker. In his report on the exhibition's progress, Picher noted that not all the works were masterpieces, but out of the ninety pieces he selected from New Brunswick, Nova Scotia, and Newfoundland, he believed fifty (or two works from each artist) would effectively represent current trends in the region. Picher identified these trends as figuration, sometimes naïve, and predominately landscape-based work, and he countered critics of the proposed exhibition by declaring that,

in my opinion, there is no doubt that this exhibition should be organized as well as any other exhibition from the rest of Canada. The question is not, in my own mind, to judge if this exhibition is d'avant-garde or not. One should only consider the qualities of authenticity and of the techniques. ${ }^{22}$ 
The most adamant critic of Some Maritime Painters was Richard Simmins, who had recently toured the Maritimes with Picher to discuss the National Gallery's extension services and denied the Sackville Art Association's request to host the Third Biennial Exhibition at the Owens Art Gallery. Simmins demanded the cancellation of Some Maritime Painters due to what he believed was low-quality art and an inability to secure the latest work by certain artists. By June 1960 Picher had drafted a letter to artists explaining the difficult situation. ${ }^{23}$

The National Gallery's new director, Charles Comfort (hired in 1960), initially favoured holding the exhibition without the latest work of Colville, Humphrey, Ross and Brittain until Simmins convinced him otherwise. ${ }^{24}$ By September, artists including Lawren P. Harris and Aileen Meagher had heard rumours of Claude Picher's upcoming resignation and were apprehensive about the exhibition's fate, but had to wait a month to hear any news. ${ }^{25}$ The official reason for the exhibition's cancellation, as told to artists contacted for Some Maritime Painters, was an insufficient amount of material, ${ }^{26}$ as many "leading" painters had prior exhibition commitments or had loaned their work. ${ }^{27}$

Several artists and the chairman of the board of trustees, Thomas Maher, were upset about this change of events. ${ }^{28}$ Maher was disturbed by the cancellation of Some Maritime Painters on the grounds of an insufficient amount of work and was embarrassed that he had publicly stated that the National Gallery would sponsor an exhibition of Atlantic Canadian artists before it had been sufficiently determined if such an exhibition was feasible, a sentiment echoed by Lawren P. Harris. ${ }^{29}$ Artists seemed to grasp the sentiment behind the official notice. Aileen Meagher noted that if artists had officially received earlier notice of the exhibition's organization they would not have been caught 
in an "unmatted-unframed-[and] general "no time to dig it out'-flap". 30 Should Colville, Humphrey, Ross and Brittain have had more than six months' notice of an upcoming, regionally-specific exhibition, more of their works would most likely have been available as well. Meagher implored Simmins, "Please - we're minor but give us a chance."31 This chance would come with the modified exhibition, entitled Six East Coast Painters, which replaced the cancelled Some Maritime Painters. Simmins was instructed "in no uncertain terms" to organize such an exhibition to placate his superiors as, in his words, "Mr. Mayer [sic] and the Maritime Trustees seem to be rather concerned."32 The format chosen followed advice given by Lawren P. Harris and was identical to the show 7 West Coast Painters, organized by the National Gallery and which was seen in 1959 at the Vancouver International Festival Exhibition. Included in Six East Coast Painters were five of the same artists Harris had recommended to Simmins for inclusion: Miller Brittain, Alex Colville, Jack Humphrey, Fred Ross, and Ruth Wainwright. He had also suggested including Robert Annand, but was himself represented in the exhibition instead. $^{33}$

Long before this alternative arrangement for representing Canada's east coast was settled, Jack Humphrey cautioned Picher that such a limited focus would not accurately show the breadth of work being done in Atlantic Canada and noted that he would dearly love to play jury to some central Canadian painters in the same spirit of ruthless private prejudice which has come to govern their judgments... It would be satisfying for once to point out their [central Canadian painters'] flaws and show these power-inflated "masters" a sample of what they disperse. ${ }^{34}$

The National Gallery attempted to placate excluded Atlantic artists with offers to hold their work for possible inclusion in the Fourth Biennial Exhibition in $1961{ }^{35}$ The friction caused by the cancellation of Some East Coast Painters and the hasty organization of its 
reduced version undoubtedly led to the lowest Atlantic representation in the biennial series at the Fourth Biennial Exhibition of Canadian Art.

\section{The Experiment Continues}

Planning the Fourth Biennial Exhibition, which opened on May 19, 1961, coincided with a tumultuous period in the National Gallery's history. Since the last biennial exhibition, John Diefenbaker's newly elected Conservative government had become embroiled in and exacerbated a debacle over the purchase of works by the National Gallery from the Prince of Liechtenstein, which ultimately saw Charles Fell (chairman of the board of trustees from 1952 to 1959$)^{36}$ and then Jarvis resign from the National Gallery in August 1959. ${ }^{37}$ Staff morale was low and the situation so discomfiting that some began looking for opportunities elsewhere. ${ }^{38}$

The Gallery was slated to move out of the Victoria Building, where it had functioned in cramped and inadequate quarters since 1920, and into the newly built Lorne Building on Elgin Street by November 1959. It remained without a director until Charles Comfort's January 1960 appointment by Cabinet, just in time for the Gallery's inaugural opening the next month. The board of trustees required reshuffling due to the loss of its chairman and the subsequent and publicly bitter resignation of trustee Cleveland Morgan after Jarvis' dismissal. ${ }^{39}$

In hiring Comfort, a well known and relatively conservative painter and former Royal Canadian Academy of Arts president, the government intended the Gallery to become less controversial than it had recently been. An attempt was made, for example, during the Fourth Biennial Exhibition of Canadian Art to mollify artists who had 
previously objected to an invitation-only arrangement and demonstrate the National Gallery's democratic mores to a public insulted by Jarvis' inflammatory comments. Comfort's tenure, however, would not ultimately be remembered as placid due to a scandal in 1965 involving the exhibition of known forgeries in the Chrysler collection (from the Chrysler Museum in Norfolk, Virginia) and Comfort's infamous disavowal of New York Pop artist Andy Warhol's Brillo Boxes as sculpture, ${ }^{40}$

In an effort to re-establish confidence and stability at the Gallery and avoid controversy, after much debate, the Gallery staff and trustees agreed upon a new selection format for the Fourth Biennial. An open submission call was the most democratic of selection formats. In addition to sending invitations to artists, the National Gallery placed advertisements in newspapers encouraging painters, draughtspersons, and printmakers, including those hitherto unknown or "undiscovered" by Gallery staff or trustees, to submit work for possible inclusion in the Fourth Biennial Exhibition of Canadian Art.

The exhibition was organized by Richard Simmins and featured a jury of five individuals drawn from across Canada, one from Europe, and no one from the National Gallery of Canada. The jury was comprised of Philip James (jury chair), secretary of the Museums Association in England; Clare Bice, curator of the Public Library and Art Museum in London, Ontario; Alex Colville, artist and associate professor of fine art at Mount Allison University; Ferdinand Eckhardt, director of the Winnipeg Art Gallery; and Jean Paul Lemieux, artist and instructor at the École des beaux-arts in Québec City. ${ }^{41}$

This submission format presented many difficulties, including monopolizing administrative, curatorial, registrar and preparatory staff for several months, necessitating 
the hiring of an outside packing company, a tremendous sum spent for advertising and return shipping, and refusals by many established artists to participate. ${ }^{42}$

A letter received by the National Gallery from Northwest Territories artist Elizabeth Templeton recounts the difficultly of finding frames in Fort Smith and marks the first instance of an artist from Northern Canada submitting art to a biennial exhibition of Canadian art. ${ }^{43}$ Jack Humphrey was one Atlantic Canadian artist who doubted that sending pieces to the Fourth Biennial Exhibition would be in the "best interests" of his work and questioned by whose standards of quality his art was being judged. ${ }^{44}$ It appears that the Gallery staff had little patience remaining for regional discontent and would have placed Humphrey into "one of the New Brunswick factions who are usually unhappy about various things". ${ }^{45}$ Proportional regional representation played no part in assembling this exhibition, as witnessed by the Atlantic region securing only 2.2 per cent of the total works chosen by the jury. Russell Harper inferred in a letter to the un-exhibited Reginald Shepherd that the lack of a National Gallery staff member on the jury was partially responsible for its lack of any reference to regions while making their selections. ${ }^{46}$

The logistical nightmare of inviting any and all artists to send a maximum of two works to Ottawa, regardless of professionalism or experience, led to approximately nineteen hundred works arriving at the National Gallery. The jury spent over two days "having a delightful time throwing out things", in the words of Harper. ${ }^{47}$ The jury used an elaborate system to select ninety pieces from the nineteen hundred works submitted to Ottawa, wherein paintings, then prints and drawings were tagged with differently shaped pieces of paper if they were accepted or rejected. Each juror had differently coloured 
pieces of paper and handlers moved the pieces about when works received four oblong strips of paper (an acceptance) or four triangular pieces (a rejection). ${ }^{48}$

Ironically, and frustratingly for exhibition organizers, while amateur artists were eager to submit works (predominantly landscapes) to the biennial jury, many of the renowned and serious avant-garde Canadian artists the Gallery wanted to exhibit objected to the selection methods or had better exhibition prospects. In a letter to Russell Harper, Jack Bush summarized his feelings by saying, "I am not at all sure that I will decide to enter The Fourth Biennial, due to several other firm commitments, as well as objecting some to this idea of jurying and pre-jurying." 49 Others, such as Harold Town and Alex Colville, were more interested in sending their work to important international exhibitions such as the São Paulo Biennale rather than to the Fourth Biennial Exhibition of Canadian Art. ${ }^{50}$

For an exhibition where "every painter in Canada [had] a chance to have his work considered", 51 the final list of artists chosen was nearly identical to those of previous biennial exhibitions. The "tendency to stick to a well-worn path" was a danger that juror Alex Colville had identified and hoped to rectify through his support of the open submission exhibition. Colville cautioned Comfort that maintaining the practices of inviting artists and using regional juries would leave the National Gallery "open to the accusation of favouring a certain clique, or certain cliques."

In their statement, the jury lamented the absence of works by un-named artists who had demonstrated the "highest standards" in past exhibitions and apologetically noted that although many good reasons existed for open submission calls, such a format did not necessarily lead to the best exhibitions. James, Bice, Colville, Eckhardt and 
Lemieux identified four broad categories of art - abstract, representational ("with some marked degree of personal vision and stylization"), academic, and naive work - with abstract art dominating the lot. They singled out for praise the work of artists in Toronto, Vancouver, and Montréal and felt that although many distinguished artists did not adhere to a particular school, groups in these cities were "a source of stimulus to their members and [had] a certain indigenous quality" while simultaneously demonstrating "international flavour". 53

The majority of the eighty-one artists included in the exhibition had participated in previous biennials (including Donald Jarvis, Tom Hodgson, Jack Shadbolt, Gordon Smith, Jacques de Tonnancour, and Harold Town - who exhibited in all four biennials and their contemporaries in Vancouver, Toronto, and Montréal); but thirty-seven new artists (approximately forty-six per cent) were also included. ${ }^{54}$ These artists were predominately from British Columbia (mainly Vancouver), which was represented by nineteen works, Ontario (or more specifically Toronto; thirty-three), and Québec (including twenty works by new artists from Montréal, Québec City, and Chicoutimi). Alberta, Saskatchewan, and Manitoba were represented by sixteen works and Atlantic Canada by a lowly two, by Fred Ross and newcomer Christopher Pratt.

Fred Ross exhibited Lorna and the Heron (subsequently purchased by the New Brunswick Museum), which reflected Ross' steadfast interest in figurative work and his shift towards portraying psychological themes in adolescent subjects. ${ }^{55}$ In 1961 , Christopher Pratt had recently returned to Newfoundland following studies at Mount Allison University and the Glasgow School of Art. His serigraph Boat in Sand was the lone Atlantic Canadian piece purchased by the National Gallery, among fifteen others, 
and evinces Pratt's passion for order and the dignity that follows it. ${ }^{56}$ Pratt has said that this work was printed during a time of change in Newfoundland, when "traditional and viable" ways of life were "being systematically discredited" ${ }^{57}$ Boat in Sand is not necessarily nostalgic for these traditional ways, but displays the dignity of ordinariness amidst political and social change that Pratt identifies as an important element in his work. $^{58}$

The Fourth Biennial Exhibition of Canadian Art travelled first to the New Brunswick Museum in Saint John along its cross-country tour, followed by Montréal's École des beaux-arts, London's Public Library and Art Museum, the MacKenzie Gallery in Regina, the Edmonton Art Gallery, the Art Gallery of Greater Victoria, and the University of British Columbia in Vancouver. Once again, critics noted that the most celebrated works mirrored paintings coming from Paris, New York, and London. One critic felt that the Fourth Biennial Exhibition of Canadian Art was repetitious, that it exhibited more of the same abstract trends seen in previous biennials, and called for a "Salon of the Rejected" so Gallery visitors could see the other side of painting in Canada. ${ }^{59}$ Perhaps the two works from Atlantic Canada cultivated such criticism.

\section{Alienation and Innovation- The Biennial Series at a Crossroads}

Soon after the Fourth Biennial Exhibition completed its tour across Canada, exhibition organizers were faced with the dilemma of how to conduct the selection process for the fifth. Austerity programming was in effect, which limited government spending and restricted the staff and time available for a Canadian survey like the last, wherein large sums were spent on returning over one thousand eight hundred artworks, many sent by individuals clearly not capable of exhibiting in such a show. ${ }^{60}$ Some established artists 
had refused to participate and sculptors grew increasingly upset that this Canadian art survey regularly failed to include their medium. ${ }^{61}$ The series' title for the following two exhibitions would reflect this omission.

After the difficulties encountered with the open exhibition of 1961, the Fifth Biennial Exhibition of Canadian Painting's organizers, National Gallery curator of Canadian art Russell Harper and director Charles Comfort, reverted to relying on regional advisors and conducting studio visits for preliminary selections. This was not an easy decision. Reminiscent of the Annual Exhibition of Canadian Painting held in 1953, debates occurred between ensuring a high-quality exhibition and exercising the Gallery's democratic and fiscal responsibility to the Canadian public through proportional regional representation. To ensure consistent quality Harper insisted that a single individual jury the exhibition. Failing that, it should be cancelled. ${ }^{62}$

Harper's ultimatum prompted Comfort to outline his reason against this "autocratic" method: his moral responsibility, as director of the National Gallery, to utilize democratic formats such as the open call, since the biennial exhibitions were supported by public funds. ${ }^{63}$ Hubbard, one of the series' original organizers, supported Comfort's position, noting that what worked in principle (reliance on a single juror) might not always work in practice and that the open submission call should be "the norm" until a better system was identified. Hubbard took this opportunity to reiterate his belief that judging "artistic quality without regard to school or style should always be our guiding principle." 64

During planning for the Fourth Biennial Exhibition Jean-René Ostiguy (education director and exhibition organizer for the third biennial) suggested using regional advisors 
to select work for regional exhibitions funded by the National Gallery as a preliminary selection method for upcoming biennial exhibitions. In this way, regional advisors would be responsible for ensuring the best representation of their respective regions, allowing the National Gallery's staff to focus on presenting and purchasing the best of these works, not on finding them.

Importantly, such a regionally-directed selection method would have fostered "a climate of confidence between regional, provincial and federal relationships ... built-up by the years because we [the National Gallery of Canada] would in no way treat the provinces or regions as children". ${ }^{65}$ Mrs. H.A. Dyde, a member of the board of trustees and Alberta resident, alerted Comfort to the alienation that artists felt following staff selections during past biennial exhibitions, highlighting the shadow of paternalization and disaffection descending upon the National Gallery in conjunction with the series. Cooperation with the regions would also "appeal to public feeling" during trying economic times and benefit the Gallery's public image. ${ }^{66}$ These were substantial issues the National Gallery could not ignore.

Momentarily divided on cancelling or postponing the exhibition, dropping the series, relying on a one-man jury or contending with a legion of regional exhibitions across the country, the trustees ultimately decided to secure the input of twenty-five honorary advisors in the Prairie and Atlantic provinces, British Columbia, Ontario, and Québec, and to send Russell Harper on a three-month studio tour from Newfoundland to British Columbia, making the selection process democratic and diplomatic. ${ }^{67}$ A jury of six made final selections and was comprised of three trustees, Thomas Maher (chairman 
of the board), J. Grant Glassco, and Jean Raymond, along with Hubbard, Harper and Kathleen Fenwick, curator of Prints and Drawings, from the National Gallery.

Honorary advisors were predominantly art school directors (such as Fred Amess, Sydney Watson, Lawren P. Harris, and Donald C. MacKay), gallery directors - including John MacGillivray (the Edmonton Art Gallery), Kenneth Saltmarche (the Art Gallery of Windsor), W.J. Withrow (the Art Gallery of Toronto), T.R. MacDonald (the Art Gallery of Hamilton), Evan H. Turner (the Montréal Museum of Fine Arts), and Edwy Cooke (the Beaverbrook Art Gallery) - and fine art professors (for example Ian McNaire, H.G. Glyde, Claude Beaulieu, and Christopher Pratt). The advisors for the Atlantic region were Lawren P. Harris, Edwy Cooke, Lucy Jarvis (former curator at the University of New Brunswick Art Centre and a Nova Scotia painter), Donald C. MacKay and Christopher Pratt. ${ }^{68}$

MacKay suggested many artists in the Halifax area who had never been approached by the National Gallery and whose work he felt suitable for the Fifth Biennial Exhibition of Canadian Painting. They included Elizabeth Annand, Anthony Law, Gordon Simmons, and Jack Gray. ${ }^{69}$ Harris added Herzl Kashetsky, Tom Forrestall, and Claude Roussel (all in New Brunswick) to the list of Atlantic artists Harper should visit. ${ }^{70}$ To expedite the Newfoundland leg of his trip, Pratt provided Harper with names of artists who would assemble their work at Memorial University for his inspection. They included Woldemar Brants, Garry Saunders, Alistair Drysdale, Reginald Shepherd and Helen Parsons Shepherd in St. John's, and Marcel Cloarec in Labrador City. Pratt also remarked, though, that much of this work would not be suitable for the exhibition, but 
that from "the diplomatic point of view it is desirable for you to make a short to visit to St. John's, even if no work is selected."71

While honorary regional advisors were suggesting new artists for the Fifth Biennial Exhibition, the National Gallery was developing a plan to open the show in London, England. Schemes for exhibiting a survey exhibition of Canadian art at the Tate Gallery had been in development for some time and offered a great deal of prestige for the National Gallery of Canada should it exhibit there. London's recently opened Commonwealth Institute was a possible venue as well. Due to mockery following its unimpressive inaugural exhibition, however, Harper was encouraged to send the potentially uneven biennial exhibition to the less prestigious of these two British galleries and reserve a future, stronger showing of Canadian art for the more prominent Tate Gallery. $^{72}$

Although the Commonwealth Institute was a second-choice venue for the Fifth Biennial Exhibition, organizers wanted to present Canada's newest, most dynamic artists. To this effect, Harper visited over two hundred and fifty artists' studios and galleries and amassed approximately three hundred artworks for the jury's evaluation. ${ }^{73}$ After touring Hamilton, London, Windsor, Toronto and Kingston, Harper visited artists in Fredericton, Saint John, St. John's, Halifax, Truro, and Sackville from January 28 to February 12, 1963 before visiting Québec and the Western centres. ${ }^{74}$ He had corresponded with a Charlottetown artist, Barry Bugden, but was unable to visit his studio due to time limitations and encouraged Bugden to send a painting to the National Gallery for the jury. ${ }^{75}$ This interaction marked the first and only biennial exhibition encounter between Prince Edward Island and the National Gallery of Canada. 
Bugden's work was not selected by the jury. Instead, Atlantic Canada was represented by six paintings by six artists: Bruno Bobak's Saint John Harbour (Bobak was then in Fredericton as University of New Brunswick artist-in-residence), along with Miller Brittain's Figure on a Beach, Alex Colville's Swimmer, Jack Humphrey's Rose Crevice, new-to-Halifax artist Carol Fraser's The New Winter Grave, and Christopher Pratt's House and Barn. ${ }^{76}$ None of these works were purchased by the Gallery. Work by Prairie artists such as Roy Kiyooka, Arthur F. McKay, Otto Donald Rogers, Ronald Bloore, Kenneth Lochhead and Ron Spickett was chosen by the jury along with regular biennial exhibitors including Jean Paul Riopelle, Harold Town, Gordon Smith, Tony Onley, Tom Hodgon, and Jean Paul Lemieux. A total of eighty-six works was selected after the jury examined thirty-two from Atlantic Canada (from which, as noted above, six were chosen), fifty-eight from Québec (twenty-six chosen), seventy-four from Ontario (twenty-three selected), fifty-five from the Prairie provinces (seventeen kept for exhibition), thirty-four from British Columbia (fourteen of which were selected), and seventeen sent in from Canadian artists abroad. ${ }^{77}$

The Fifth Biennial Exhibition of Canadian Painting opened on June 13, 1963 at London's Commonwealth Institute by Indian president Dr. Radhakrishnan in the presence of Queen Elizabeth and Prince Philip. In his foreword to the exhibition catalogue, Charles Comfort celebrated Harper's “homeric journey” across Canada and noted the satisfaction felt in assembling the Fifth Biennial Exhibition and sharing it with the British public, who might be as surprised as the jury was to see what discoveries Canada's young painters had made and to find them rediscovering the figure in their work. $^{78}$ 
In an effort to identify the varied threads in Canadian art, Harper asked in his exhibition catalogue essay how one might judge the merit of paintings. Is merit to be found, he pondered, in a "textural quality", through the digestion of trends or international influence, in inventiveness, or can it be found in craftsmanship and in the "sincere, emotive statements" of "regional workers"? ${ }^{79}$ In response to his questions, Harper examined each region's artwork and highlighted his uneasiness with Atlantic Canadian art.

Harper recounted that in his discussions with artists (not workers) in Ontario and Québec they demonstrated their doubts about possible future directions of abstract art and predicted a return to figurative painting. He claimed, however, that Atlantic Canadian workers "cling tenaciously to figurative painting" with only sparse (and unnamed) studios creating non-objective work. Harper identified the Beaverbrook Art Gallery and universities (the University of New Brunswick, Mount Allison University, the Nova Scotia College of Art, and Memorial University) as reinforcing this preoccupation with the figure. Instead of seeing the work of Colville, Annand or Ross as anticipating or leading a Canadian resurgence in figurative painting, Harper saw these Atlantic artists' subjects as traditional: something to hang on to. Conversely, Harper celebrated "serious" artists, with "rigorous art training" and "nothing whimsical in their makeup" from Ontario, Winnipeg and Calgary for giving the "most reasoned Canadian attack against the abstract and non-objective approach" by "exploring nostalgia... and social realism" in their work and even looking back to Renaissance themes. ${ }^{80}$ In doing so, Harper blatantly ignored the work Atlantic Canadian artists had done. As a former archivist of the New Brunswick Museum and curator at the Beaverbrook Art Gallery, Harper was well 
acquainted with the history of Atlantic Canadian art and in a position to represent its contemporary breadth and seriousness. Although he was certainly an expert on the Atlantic region's importance in Canada's art historical past (as his writings and exhibitions testify), in this exhibition catalogue essay he does not celebrate the latest developments in Atlantic Canadian art. ${ }^{81}$

For example, Christopher Pratt, whose work innovatively explores nostalgia and change in Newfoundland, was not mentioned in Harper's paragraph on the province. Instead, Newfoundland artists were criticized for modernizing their landscapes, unaware of the authenticity they were losing by their "reluctance to use Canadian motifs and paint 'Canadian"” by not painting the sea and shoreline. ${ }^{82}$ Painting "Canadian" had not been encouraged by the National Gallery for a long time and was not celebrated in the biennial exhibitions. Harper identified this modernist shift as an "inferiority complex towards their [Newfoundlanders'] own artistic convictions and their own surroundings". 83 Perhaps this lament points to Harper's nostalgia for a time when Atlantic Canadian art could easily be equated with the past, pigeonholed as military views and comforting landscapes. The Atlantic scene had changed.

Saint John artists Miller Brittain and Jack Humphrey had been among Canada's foremost social realist artists. But Brittain's focus shifted dramatically by the 1960 s, becoming increasingly esoteric, formal, and psychological, reflecting his desire to incorporate "such abstract qualities as love, despair, terror, and so on...the inevitable expression of Everyman" into his work. ${ }^{84}$ Harper overlooked Brittain's originality in his catalogue essay. By the 1960s Humphrey too shifted to increasingly non-objective and experimental subjects. He aimed to reconcile "quality which is as universal as it is 
contemporary while surrounded by purely regional nourishment." Ironically, Harper would write an essay for Humphrey's posthumous retrospective three years later, praising the painter for his awareness of American and international trends and noting the experimental work Humphrey completed on visits to New York. ${ }^{85}$ Very little "clinging" is visible in the work of these two artists included in the biennial exhibitions. After predicting a resurgence of figurative painting, Harper does not comment on Fred Ross' contribution to the genre, as his portraits of the proud yet vulnerable "leather jacket boys" of Saint John and other adolescents demonstrate. ${ }^{86}$

Although Harper must have been aware of recent trajectories in Ross's and other painters' work - thanks to the 1961 exhibition Six East Coast Painters, which highlighted an arc of figurative representation in Atlantic Canada ${ }^{87}$ - his essay for the Fifth Biennial Exhibition of Canadian Painting cloyingly minimizes the strength, seriousness, and momentum of contemporary painting in the Atlantic region. The contrasts he formulated between art and artists from Atlantic Canada (clinging, lagging, promising but unaware) and centres such as Montréal, Toronto and Vancouver (well-trained, serious, and successful) are ill-considered. ${ }^{88}$

The connections Harper drew between preoccupations with the past and Atlantic Canadian art encouraged reviewers to disparage the region's art. Christopher Pratt's journal entries from 1964 attest to the weight of these damaging comments. Pratt notes David Silcox's discussion in Canadian Art on the London reaction to the exhibition, writing,

he makes light of the coverage in what he calls, properly I think, the "large circulation, low mentality dailies" and refers to the reviews in the "astute" papers as "brief, patronizing notices." He quotes as most significant the Apollo review, which finished with the observation that "the sprinkling of what could be called 
'traditional' painting is so bad as to be embarrassing." Presumably, my offering... was one of, if not the most 'traditional' painting of the group. ${ }^{89}$

This comment and others, from John Russell (referring in Art News to an award given to Colville "only by an apotheosis of hick taste") and Diana Armatage (discussing in Canadian Art Mount Allison students' concern with making heartless and dull "pictures of things, rather than making paintings") on Atlantic art in other shows, made Pratt "find it difficult to muster enough self-confidence and feeling to continue with my work". 90 Pratt criticized Canadian Art for not reviewing the Fifth Biennial Exhibition and noted his suspicion of its editors,

wish[ing] to align themselves with the international sophistication of the London reaction by inference. Perhaps they consider an exhibition, selected coast to coast with 'Hockey Night in Canada' patriotism, and containing examples of the provincial as well as the metropolitan styles, to be academic in the old sense and damaging to Canada's reputation, and by extension their own, when sent abroad? ${ }^{91}$

In the Canadian press, Prairie artists (such as Roy Kiyooka, Arthur McKay, Otto Donald Rogers, Glen Toppings, George Wood, Ronald Bloore, Kenneth Lochhead, Ronald Spickett and Jan Wyers) represented in the fifth biennial were celebrated for having "taken on a vigorous, eye-catching New York sophistication". 92 Canadian artists' assimilation of avant-garde trends from New York, London, and Paris was derided by several European critics (including the Manchester Guardian's Eric Newton and the Evening Standard's John Richardson) who felt that this must be internalized and made Canadian. ${ }^{93}$ The Ottawa Citizen's Carl Weiselberger expressed a diplomatic view of the exhibition, claiming that Canadian artists were holding their own despite the stimulus of international styles. ${ }^{94}$ On a positive note, Oswell Blakeston of The Arts Review in London believed international influences as varied as Clement Greenberg's impact at the 
Emma Lake Workshop and Japanese store fronts in Vancouver positively shaped Canadian art and lent it a distinct flavour. Blakeston characterized Carol Fraser's New Winter Grave (celebrated as powerful and moving by other critics) as a "Canadian weather report". 95

Across the regions, however, artists in Canada took issue with this biennial exhibition. Toronto artist and National Gallery trustee Frank Panabaker believed the series should be dropped, as it was a "waste of money" and not a proper survey of "the best" in Canadian painting as the finest artists were growing so "cooly [sic] indifferent" that they refused to submit their work. ${ }^{96}$ The Shepherds in St. John's felt that regardless of what was submitted to the jury, Harper had already chosen the final works before seeing the full range of submissions. ${ }^{97}$ Toronto artist Dennis Burton demanded to know who had been chosen as honorary advisors to devise a list of artists, calling the Fifth Biennial Exhibition of Canadian Painting a "Comfort-able show" that blatantly ignored some of the best artists in Canada and aimed to be a "safe, sure, and uncontroversial" exhibition for the mother country. ${ }^{98}$ Artist Eli Bornstein at the University of Saskatchewan commented that "although it may soothe the conscience of galleries and museums to organize exhibitions of this kind, I am quite convinced that it is unfair to the art and the artists concerned to have separate, isolated examples [of their work] thrown together in such a potpourri. ${ }^{, 99}$ Also, not all artists were interested in participating in a travelling survey exhibition due to the potential loss of sales at commercial galleries, and would rather retain work for upcoming solo exhibitions in Canada and the United States. ${ }^{100}$ 


\section{The Series Unravels}

As 1965 approached, the National Gallery's staff was showing definite signs of weariness and inertia with regards to the biennial exhibition series. Although staff spent countless hours organizing the exhibitions of Canadian art and fending off the growing Canadian criticism encountered in conjunction with the series, smaller, more focused shows of small groups of Canadian artists were more successful. Exhibitions of regional work such as Five Painters from Regina (exhibited in 1961) and Canadian art in international venues such as the Venice and São Paulo Biennales and the Primera Bienal Americana de Grabada in Santiago, Chile were celebrated and reflected positively on the National Gallery, in contrast with the biennials of Canadian art. ${ }^{101}$

In 1963, Russell Harper left the National Gallery making the task of selecting works for the Sixth Biennial Exhibition of Canadian Painting (1965) even more problematic, since there was no obvious person to head the project. Other curators were "madly busy" and had little time to devote to the next biennial, ${ }^{102}$ let alone attempt to organize a system of regional juries similar to what Ostiguy had suggested four years earlier and which the trustees were proposing for this show. ${ }^{103}$ Their solution was to rely on an outside individual to compile and select artwork.

Philip James, the Gallery's London advisor, was suggested for his prestige (gained through "his association with the recent Gulbenkian exhibition at the Tate") and previous work as a juror for the Fourth Biennial Exhibition, as was French art critic Pierre Restany. ${ }^{104}$ William Townsend, painter and at that time Fine Arts professor at the Slade School at University College London and visiting professor at the Banff School of Fine Arts, was chosen instead. 
Townsend promised to bring a "most genuine enthusiasm for the project in hand" and select an exhibition that properly reflected "the vitality and enterprise of the artists who are at work in Canada today." 105 Before embarking on a two-part journey across Canada in autumn 1964 (interrupted by responsibilities in England), Townsend received the advice of twenty-seven honorary advisors across the country. Many of these advisors had been previously involved with the process, but some were new to it, including Peter Bell at Memorial University's Art Centre, Stuart Smith, curator at the Beaverbrook Art Gallery, Jean-Paul Morisset in Québec City (the Gallery's Eastern liaison officer since 1962), Edward Lawson (curator) and Guy Viau (artist) in Montréal, Ralph Allen in Kingston (director of the Agnes Etherington Art Centre), and Samuel J. Zacks (art collector and patron) and John C. Parkin (architect) in Toronto. On the Prairies, Richard E. Williams (artist) of Winnipeg, John Climer (director-curator of the Mendel Art Gallery) and F.S. Mendel (businessman and arts benefactor) in Saskatoon, A.F. Key (director of the Calgary Allied Arts Centre) in Calgary, and Doris Shadbolt (curator at Vancouver Art Gallery) guided Townsend toward new artists and those whose work had developed. ${ }^{106}$ Artists and dealers were urged through newspaper notices (in Montréal, Toronto, Ottawa, and Vancouver only) to make their best works available for Townsend's upcoming inspection. ${ }^{107}$ No Canadians abroad were invited to submit artwork.

After seeing the work of approximately three hundred and fifty painters in nineteen cities where he attended solo exhibitions, made studio visits, and viewed assembled works in central venues such as Memorial University's Art Centre, Townsend 
chose 150 pieces in his preliminary selection. Upon further viewing, this number was whittled down to 114 , with ninety artists represented.

From the Atlantic coast, only one new artist was exhibited, Jeffrey Ervin Poklen, a California-born painter teaching at Mount Allison University. Poklen might not have been "found" if Townsend's time in this region had not been extended from two to five days. ${ }^{108}$ Poklen's painting Hybrid was initially selected along with Pratt's Woman at a Dresser, two paintings by Carol Fraser (Hillside and Jim, John, \& Coltrane), Ruth Wainwright's Landscape of the Fish, Lawren P. Harris' Midnight Chimes, and work from Bruno and Molly Lamb Bobak (Roses \& Daisies and Holiday Town, respectively). Molly Lamb Bobak's painting did not survive Townsend's final selection. Fraser's Enclosed Garden was substituted for Hillside. All other works resisted elimination during Townsend's final selection. ${ }^{109}$

Young artists, such as Terrence Syverson (Saskatchewan born but then residing in New York), Claude Tousignant and Yves Gaucher of Montréal, were particularly fascinating to Townsend, as were the stimulating visits he made to studios of Vancouver and Saskatchewan artists. Kenneth Lochhead, Guido Molinari, Jacques Hurtubise, Charles Robb, and Les Levine (living in New York but formerly of Toronto) were celebrated for their "excessive simplicity of form" which Townsend believed communicated a great deal through "inflections of wrist and arm". Townsend identified Marcelle Maltais and Lise Gervais as the saviours of an otherwise languishing Montréal ${ }^{110}$ but did not specifically report his views on developments in Atlantic Canada. Of the twenty works purchased, only Carol Fraser's Enclosed Garden was selected from the Atlantic region. 
Townsend referred to "primitive painters" of whose importance he was persuaded but whose work (he does not explicitly say to whom he was referring) was "missing something". To whom did he refer as "local assets, whose work has a touching charm and the interest we find in recognizing scenes recorded with affection for their details" or those "who were apparently cultivating, with some professional skill and purpose, an innocent formula that would preserve an illusion of naïve vision and untutored hand"? ${ }^{111}$ No marginalia or rough drafts indicate who these artists may have been. Could this preserved illusion relate to Pratt's Woman at Dresser, which one critic likened to "a moment of arrested time in the tradition of Colville realism"? ${ }^{112}$

Townsend did not aim for a true survey of all of Canadian art, a goal detractors felt the National Gallery had fallen short of meeting in previous biennial exhibitions. ${ }^{113}$ He was instead instructed to look for new talent and new directions taken by established artists. He certainly located promising developments, as nearly half the artists were new to the biennial series. ${ }^{114}$ The trustees placed Townsend under no obligation to represent all the provinces or to meet a quota from each region. ${ }^{115}$ Should any criticism arise about his selections, Townsend personally accepted responsibility for any "oversights and faults of emphasis" in the exhibition although the National Gallery was ultimately responsible for his directions. ${ }^{116}$

After the Sixth Biennial Exhibition opened on June 4, 1965, critics praised the lone British juror's choices, his view that "the continuation of activity already acclaimed is not a discovery", and his proclamation that Canadian art had little to do anymore with the wilderness. ${ }^{117}$ Jarvis had voiced that sentiment since 1959 but the more conservative 
Harper - in his Fourth Biennial Exhibition catalogue essay - was conflicted about the absence of this in Canadian art. ${ }^{18}$

Not only was the resulting exhibition deemed successful, but the selection format relieved curators of organizational burdens and positioned the National Gallery alongside Canadian and international galleries that had also begun relying on particular art authorities for exhibitions rather than groups whose members' views led to compromising and "discouragingly pedestrian" exhibitions. ${ }^{119}$ In making this connection in his exhibition catalogue introduction, Comfort was apparently referencing and breaking away from previous biennials.

After its Ottawa showing, the exhibition travelled across Canada (although in a reduced version due to some works' fragility), stopping at the customary galleries in New Brunswick (the Beaverbrook Art Gallery), Québec, Ontario, Manitoba, Saskatchewan, Alberta and British Columbia. There was a push for it to spend time on the Prairies the artists from which were well represented (with twenty-four works). This was an effort to "establish their reputations on (more-or-less indifferent) home ground." ${ }^{120}$ In response, the exhibition spent eighty days in the region.

Other "more-or-less indifferent" hometowns might have included St. John's ("a land of many small rivalries and jealousies" whose artists produced "hundreds" of inferior works, according to Peter Bell) ${ }^{121}$ and Halifax. Although the Beaverbrook Art Gallery had proved significant enough to associate with the National Gallery of Canada and host the occasional biennial exhibition, Nova Scotia had not seen one since 1955. Newfoundland and Prince Edward Island never saw any. Transportation costs were 
probably not a factor, since the last biennial exhibition had been shipped to and from London for a glamorous opening.

A definitive swing toward aligning with the international art world (reminiscent of Jarvis' intentions) occurred for the National Gallery with Charles Comfort's retirement in 1965 and the appointment of American-educated (but Canadian) Degas scholar Jean Sutherland Boggs on June 1, 1966. Momentously, Boggs began acquiring photographs as well as modern and contemporary American art. These acts signaled a radical break with the Gallery's earlier policies on excluding American art and made clear the Gallery's newfound desire to take seriously, and be taken seriously on, the international art scene. ${ }^{122}$ After all, the world's eyes were on Canada as the country made preparations for its centennial and Montréal was poised to host a global audience as the site of the 1967 International and Universal Exposition, or Expo 67 as it was commonly known.

In 1966, National Gallery staff busily prepared exhibitions to open the following year, including historical surveys of Canadian art from all corners of the country. These included Canadian Painting, 1850-1950; Cape Dorset: A Decade of Eskimo Prints and Recent Sculptures; Design Canada, 1867-1967; Three Hundred Years of Canadian Art (also shown at the Art Gallery of Ontario); Prints from the Sixties; a photographic exhibition of Québec architecture; exhibitions of recent acquisitions and contemporary Canadian art; retrospectives of work by Ernest Lawson, John Lyman, Jean Paul Lemieux; and several exhibitions reflecting the National Gallery's interest and involvement in the global arts community. In addition to mounting exhibitions of Ethiopian illuminated manuscripts, reproductions from the French Embassy of French painting from 1863 to 1960, works from Poland, Spain, and Russia, along with Australian prints, the National 
Gallery sent exhibitions to Australia, to the 5e Biennale de Paris, the International Fine Arts Exhibition at Expo 67, São Paulo’s IX Biennale, and the Fifth Guggenheim International Exhibition (to which it contributed Canadian sculpture). There could be little doubt among members of the international art community about the National Gallery's arrival on the global stage after such frenzied activity.

With centennial momentum being directed to other projects, the Seventh Biennial Exhibition of Canadian Art was put on hold and rescheduled to open on July 5, 1968 instead of in 1967. The efficient selection method chosen for the last biennial was employed once again, although Boggs was determined - after relying on international advisors when organizing the exhibition for Expo 67 - to consult Canadian experts "whenever possible" in the future. ${ }^{123}$ Nevertheless, William Seitz, Director of the Rose Art Museum at Brandeis University, Massachusetts, was appointed to travel the country with the assistance of Richard Graburn, executive assistant to Boggs, to make initial and final selections for the Seventh Biennial Exhibition of Canadian Art. Junior curators Pierre Théberge and Dennis Reid provided assistance with travel and catalogue biographies (respectively) as needed, but gone were the days of heavy trustee and senior staff involvement with the series.

Lawren S. Harris had retired from the board of trustees in 1963, at a time when proportional regional representation in the biennial series was foundering and inconsistent. Five years later, in the Seventh Biennial Exhibition, the veneer of regional inclusion faded completely as no regional advisors were retained or local advice sought, and Seitz was instructed to ignore geographical representation. ${ }^{124}$ Regardless, on his seven-week tour Seitz uncovered a "new regionalism" in Canadian art, predominantly in 
Sackville, London, and Saskatchewan. "Small-town vigour" was found around Mount Allison University (incarnated in Mount Allison fine arts instructor and painter David Samilia's canvas-wrapped, assembled plywood shapes) ${ }^{125}$ and the Emma Lake Artists' Workshop. Seitz attributed the energy and intensity of these centres to technological advances which allowed artists to communicate and share ideas more easily with each other. He credited Canada's "accelerating vitality" (witnessed during his visits to more than one hundred and eighty artists in eighteen cities) to the local and to small milieus. ${ }^{126}$

But for all of his emphasis on small-town community "ferment and achievement" and the remarkable art training at Mount Allison University, Seitz lavishly exhibited and praised the work of - unsurprisingly - Vancouver, Toronto, and Montréal artists, even while criticizing their lack of a self-generating scene and linking studios there to Los Angeles, New York, and London. ${ }^{127}$ The exhibition represented British Columbia with twenty nine-paintings, Alberta with nine, Saskatchewan with twenty-one, Manitoba with three, and Ontario and Québec with thirty-two each out of a record total of one hundred and thirty-five pieces. The Atlantic region was represented by Samila's five works, and one painting each from Colville, Harris, Poklen, and Pratt. ${ }^{128}$ Fifteen artists warranted the distinction of exhibiting five paintings each: Jack Bush, Paterson Ewen, Brian Fisher, Reg Holmes, Ernest Lindner, Jan Menses, Guido Molinari, Kazuo Nakamura, Iain Baxter, Toni Onley, William Perehudoff, Bodo Pfeifer, David Samila, Takao Tanabe, and Harold Town. $^{129}$

\section{The Final Biennial Exhibition}

Foretelling the impending demise of the series, Seitz wrote in his juror's statement that the work found within Canada had become too varied to be summarized in a biennial 
exhibition, that "Art in Canada is already too multiform and copious to present painting, drawing, graphics and sculpture [although this never occurred] ... in a single exhibition." 130 Critics readily picked up the inference that the biennial series was losing its relevance and forecast its end with headlines such as "We've Outgrown Biennials" and "Days of Biennials Numbered?"131 Critics also noted that the exhibition distorted what was actually being produced in Canada, was argued that it was too heavily weighted towards the Prairie provinces, and amounted to an exercise in cultural colonialism. ${ }^{132}$ In the minds of already established and recognized artists (biennial exhibition veterans like William Ronald, who called the shows "a drag") the exhibitions inconveniently tied up paintings that could be sold or exhibited in other major shows. ${ }^{133}$ For a large group of Canadian painters, the series had helped them become known but was worn out. The National Gallery acquired contemporary art through other exhibitions and devised other methods to better showcase Canadian art. One such program, organized by the Gallery's newly formed International Exhibitions Department, sent exhibitions such as Canada-Art Aujourd'hui to Europe on exchange. This exhibition, not the biennial, was promoted as the "most important exhibition of contemporary Canadian art." The biennial exhibition remained in Ottawa, as if touring was meaningless by this point; it had been replaced by better shows. $^{134}$

Regardless of how much clamour Canadian art provoked through mirroring international currents or how little Canadian nationalism was now involved in Canadian artmaking, an American juror's presence generated a tension not seen or heard when Townsend, with his British and Canadian affiliations, literally ran the preceding show. The avid Canadian nationalist Barry Lord wrote: 
This is a Biennial that does not do its job. It undoubtedly does represent the taste of one well-known U.S. museum curator. Some of the work that Seitz liked would undoubtedly be approved in New York. In the days when U.S. approval seemed important, that would have been enough. Today, when we see U.S. civilization in far more dubious perspective, while recognizing the validity of our own culture with post-Expo confidence, it doesn't seem to matter very much. ${ }^{135}$

Perhaps one of the series' original motivations to show a country unified through the visual arts - and mandated by the Massey Commission to build a united Canadian identity impenetrable to American mass media - had resulted in increased confidence in some cities' artists. The Seventh Biennial Exhibition of Canadian Art proved that artists and critics in centres such as Montréal, Toronto, Regina, and Vancouver no longer required experts (from anywhere) to accumulate and show them their best paintings.

Such independence was, however, well cultivated in Atlantic artists. Over the course of the biennial series, wavering inclusion in the exhibitions and their tours, deprecating and dismissive views of the region's art, and the National Gallery's steadily growing international stature did little to inspire Atlantic artists' confidence in the Gallery and in its ability to accurately present a cross-section the country's art or examine the Atlantic region. There was no longer an H.O. McCurry emphatically calling for the proportional regional representation which initially led to a large amount of Atlantic art being shown and purchased. American, British, or Canadian, biennial jurors seemed to consistently confirm Atlantic Canadian artists' beliefs in a centrally-dominated, Ontario and Québec-centric Canadian art world. But perhaps these realizations provided the impetus the Atlantic provinces needed to become more proactive in guiding their own exhibition and art education infrastructure. Although by July 1968 the region's art scene was burgeoning - in a way that curators at the National Gallery had not forecast; after that date it would explode. 
Endnotes

${ }^{1}$ Greenberg certainly did not present any Atlantic Canadian artists with exhibition opportunities. See Dennis Reid, A Concise History of Canadian Painting, $2^{\text {nd }}$ ed. (Toronto: Oxford University Press, 1988), 283.

2 "General Information and Proposals that were agreed upon Tuesday November 25, 1958", The Third Biennial of Canadian Art, Vol. 1, NGA.

${ }^{3}$ Letter from Jarvis to Gordon Bailey Washburn, 15 January 1959, The Third Biennial of Canadian Art Vol. 1, NGA.

${ }^{4}$ Peter Larisey, Light for a Cold Land: Lawren Harris' Work and Life - An Interpretation (Toronto: Dundurn Press, 1993), 155-156.

${ }^{5}$ See Paul Dumas, Picher (Ottawa: Éditions Marcel Broquet Inc., 1981).

6 "General Information and Proposals that were agreed upon Tuesday November 25, 1958", The Third Biennial of Canadian Art, Vol. 1, NGA.

${ }^{7}$ Minutes of Meeting of Executive, 3 and Minutes of the Annual Meeting of the MAA 1957-58, 5, Vol. 501 , file 6, NSARM.

${ }^{8}$ Telegraph from Picher to Ostiguy, 3 March 1959, , The Third Biennial of Canadian Art, Vol. 4, NGA.

${ }^{9}$ Letter from Ostiguy to Picher suggesting artists to invite from Atlantic Canada, 27 January 1959, The Third Biennial of Canadian Art, Vol. 1, NGA.

${ }^{10}$ Douglas Lochhead information from Bill Hamilton, "Looking Into Trees Attracting Widespread Attention," The Sackville Tribune Post (13 January 2010): < http://www.sackvilletribunepost.com/Opinion /Columns/2010-01-13/article-894675/Looking-Into-Trees-attracting-widespread-attention/1>.

${ }^{11}$ Entry forms, The Third Biennial of Canadian Art, NGA.

${ }^{12}$ See correspondence between Ostiguy and G. A. Frecker, Newfounland Deputy Minister of Education regarding Newfoundland throughout February 1959, The Third Biennial of Canadian Art, Vols. 2-3, NGA. ${ }^{13}$ Entry forms, The Third Biennial of Canadian Art, NGA.

${ }^{14}$ Acceptance letters from Ostiguy to artists, 12 to 20 May 1959, The Third Biennial of Canadian Art, Vol. 6, NGA.

${ }^{15}$ Jarvis reports to Charles Fell, Chairman of Board of Trustees, 23 June 1959, The Third Biennial of Canadian Art, Vol. 8, NGA.

${ }^{16}$ High Diver was submitted by Colville, rejected for the Third Biennial, but purchased for the permanent collection. See list from 1 June 1959, The Third Biennial of Canadian Art, Vol. 7 and also letter from Hubbard to Colville, 9 June 1959 and memo to Simmins 5 October 1959, The Third Biennial of Canadian Art, Vol. 8, NGA.

${ }^{17}$ Simmins to Boorne, 29 September 1959, The Third Biennial of Canadian Art, Vol. 9, NGA.

${ }^{18}$ Boorne to Simmins, 8 October 1959, The Third Biennial of Canadian Art, Vol. 9, NGA.

19 "Famous Art Exhibition Opening Tonight", The Daily Gleaner, Fredericton, 2 May 1960. The cream of New Brunswick society, including Premier Hugh John Flemming and UNB President Dr. Colin B. Mackay, along with Picher, Charles Comfort, Flemington and Thomas Maher from the National Gallery attended the opening night of the Third Biennial Exhibition of Canadian Art at the Beaverbrook Art Gallery on 3 May 1960. Ted Guidry, "National Gallery Exhibition Here Scores Great Success As More Than 300 Attend", The Daily Gleaner, Fredericton, 3 May 1960, The Third Biennial of Canadian Art, Vol. 10, NGA. Jarvis was quick to disregard the Beaverbrook Art Gallery's success by highlighting its European connection. Robert McKeown (interviewer), "Is Art Necessary?" Weekend Magazine, vol. 6, no. 20 (19 May 1956): 4. ${ }^{20}$ Ted Guidry, "National Gallery Exhibition Here Scores Great Success As More Than 300 Attend", The Daily Gleaner, Fredericton, 3 May 1960, The Third Biennial of Canadian Art, Vol. 10, NGA. Maher replaced Charles Fell.

${ }^{21}$ Lawren P. Harris to Ostiguy, 1 April 1957, The Third Biennial of Canadian Art, File 3, NGA.

${ }^{22}$ Claude Picher, Report on Maritimes Painters, 14 April 1960, East Coast Painters, Vol. 1, NGA.

${ }^{23}$ Picher to Comfort, 25 August 1960, East Coast Painters, Vol. 1, NGA.

${ }^{24}$ Memorandum from Comfort to Simmins with marginalia by Simmins regarding a 28 September 1960 conversation with Comfort, 2 September 1960, East Coast Painters, Vol. 2, NGA.

${ }^{25}$ Letter from Harris to Russell Harper, 2 September 1960. Letter from Meagher, 12 September 1960. East Coast Painters, Vol. 2, NGA. 
${ }^{26}$ Draft, letter from Simmins to LeBreton, June 1960, East Coast Painters, Vol. 2, NGA. Simmins notes that Comfort phoned and approved this draft letter for mailing to artists affected by the changes with the exhibition.

${ }^{27}$ The "leading" painters were the ones already familiar to the National Gallery. Comfort to Humphrey, 4 October 1960, East Coast Painters, Vol. 2, NGA.

${ }^{28}$ Maher was chairman of the National Gallery of Canada's Board of Trustees from 1959 to 1964. See A.L. Tunnell, Canadian Who's Who: 1967-1969, Vol. XI (Toronto: University of Toronto Press, 1969), 698.

${ }^{29}$ Letter from Maher to Comfort, 31 October 1960. Letter from Harris to Simmins, 14 October 1960. East Coast Painters, Vol. 2, NGA.

${ }^{30}$ Letter from Meagher to Simmins, 17 October 1960, East Coast Painters, Vol. 2, NGA.

${ }^{31}$ Ibid.

${ }^{32}$ Simmins to Norah McCullogh, 9 November 1960, East Coast Painters, Vol. 2, NGA.

${ }^{33}$ Harris to Simmins, 21 October 1960, East Coast Painters, Vol. 2, NGA.

${ }^{34}$ Humphrey to Picher, 28 June 1960, East Coast Painters, Vol. 1, NGA. Humphrey was not involved in organizing the exhibitions Some Maritime Painters or Six East Coast Painters.

${ }^{35}$ Draft, letter from Simmins to LeBreton, June 1960, East Coast Painters, Vol. 2, NGA.

${ }^{36}$ For more information on Fell see A.L. Tunnell, Canadian Who's Who: 1961-1963, Vol. IX (Toronto: University of Toronto Press, 1963), 348.

${ }^{37}$ Andrew Horrall, Bringing Art to Life: A Biography of Alan Jarvis (Montréal and Kingston: McGillQueen's University Press, 2009), 283-294. It is generally agreed by Jarvis' contemporaries and National Gallery of Canada historians to have been a forced resignation.

${ }^{38}$ Ibid., 297-298. Indeed, Hubbard resigned in October 1960 while Comfort began transferring the Gallery's Design Centre (Buchanan's personal project for over ten years) to the Department of Trade and Commerce. See Ord, 171.

${ }^{39}$ Horrall, 295.

${ }^{40}$ Ord, 175-179.

${ }^{41}$ Press release, "Biennial Works Selected by International Jury," 14 April 1961, Fourth Biennial of Canadian Art, Vol. 5, NGA.

${ }^{42}$ See letter outlining problems with Fourth Biennial Exhibition of Canadian Art in Fourth Biennial of Canadian Art, Vol. 1, NGA. The hiring of an outside packing company is referred to in Fourth Biennial of Canadian Art, Vol. 6, NGA.

${ }^{43}$ Letter from Elizabeth Templeton to NGC, 15 February 1961, Fourth Biennial of Canadian Art, Vol. 2, NGA.

${ }^{44}$ Letter from Humphrey to Harper, 31 December 1960, Fourth Biennial of Canadian Art, Vol. 1, NGA.

${ }^{45}$ Russell Harper placed New Brunswick painter Julia Crawford in one such faction. Memo from Harper to Comfort, 1 December 1960, Fourth Biennial of Canadian Art, Vol. 1, NGA.

${ }^{46}$ Harper to Shepherd, 19 June 1961, Fourth Biennial of Canadian Art, Vol. 6, NGA.

${ }^{47}$ Letter from Harper to Hubbard, 5 April 1961, Fourth Biennial of Canadian Art, Vol. 4, NGA.

Correspondence regarding the exhibition's organization and attesting to the difficulties encountered when coordinating such a large volume of submissions from inexperienced painters can be found in this volume as well. Entry forms are found in Fourth Biennial of Canadian Art, Vols. 23-43, NGA.

48 "IV Biennial Exhibition: National Gallery of Canada - Information for Jury Members", 17 January 1961, Fourth Biennial of Canadian Art, Vol. 1, NGA.

${ }^{49}$ Jack Bush to Russell Harper, 12 December 1962, Fifth Biennial Exhibition of Canadian Painting, Vol. 7 , NGA. Bush wrote this as planning was underway for the fifth biennial, demonstrating how little he was concerned with the series.

${ }^{50}$ Harold Town to Russell Harper, 24 February 1961, Fifth Biennial Exhibition of Canadian Painting, Vol. 2, NGA. See correspondence between Harper and Clare Bice regarding Colville's Boy, Dog, and Saint John River going to the Sao Paulo Biennale, April 1961, Fourth Biennial of Canadian Art, Vol. 5

${ }^{51}$ Press release, "Biennial Exhibition Now Open to All", 8 November 1960, Fourth Biennial of Canadian Art, Vol. 1, NGA.

${ }^{52}$ Letter from Colville to Comfort, 3 August 1960, Fourth Biennial of Canadian Art, Vol. 1, NGA.

${ }^{53}$ Untitled jury statement, signed by James, Bice, Colville, Eckhardt, Lemieux, no date, Fourth Biennial of Canadian Art, Vol. 9, NGA. 
${ }^{54}$ Press Release, "Young Artists Well Represented in Fourth Biennial of Canadian Art," 19 May 1961, Fourth Biennial of Canadian Art, Vol. 6, NGA.

${ }^{55}$ Tom Smart, The Art of Fred Ross: A Timeless Humanism (Fredericton: Goose Lane Editions and The Beaverbrook Art Gallery, 1993), 57.

${ }^{56}$ Doris Shadbolt in conversation with Christopher Pratt, in Christopher Pratt, exhibition catalogue accompanying exhibit, organized and circulated by Memorial University of Newfoundland, Arts and Culture Centre, 6 - 31 July 1970 (St. Johns: Memorial University of Newfoundland, Arts and Culture Centre, 1970), 5 .

${ }^{57}$ National Gallery of Canada, CyberMuse Artwork Page, "Boat in Sand by Christopher Pratt": $<$ http://cybermuse.gallery.ca/cybermuse/search/artwork_e.jsp?mkey=6016>.

${ }^{58}$ Christopher Pratt, Ordinary Things: A Different Kind of Voyage (St. John's: Breakwater Books Ltd., 2009), prologue.

59 "Canadian Biennial: We Propose Salon of the Rejected!" Ottawa Citizen, 8 July 1961, n.p. Fourth Biennial of Canadian Art Doc files, NGA.

${ }^{60}$ The indignant letter by rejected "bird artist" Glen Ryder typifies amateur artists who sent work to the jury in Ottawa for the Fourth Biennial Exhibition of Canadian Art. From Ryder to the National Gallery of Canada, 21 April 1961, Fourth Biennial of Canadian Art, Vol. 5, NGA.

${ }^{61}$ Letter from Art Price to Harper, 15 November 1960, Fourth Biennial of Canadian Art, Vol. 1, NGA.

${ }^{62}$ Memo from Russell Harper, no date, Fifth Biennial Exhibition of Canadian Painting, Vol. 1, NGA.

${ }^{63}$ This approach was reminiscent of McCurry's egalitarian stance during the Annual Exhibition and the first biennial. Letter from Comfort to Chairman and members of the Board of Trustees, 31 July 1962, Fifth Biennial Exhibition of Canadian Painting, Vol. 1, NGA.

${ }^{64}$ Memorandum from Hubbard to Comfort, 1 August 1962, Fifth Biennial Exhibition of Canadian Painting, Vol. 1, NGA.

${ }^{65}$ Letter from Ostiguy (presumably to Comfort, Buchanan, Hubbard, Simmins and Picher as they had been corresponding regarding a new policy for biennial exhibitions), "Further to Biennial Policy," 17 June 1960, Fourth Biennial of Canadian Art, Vol. 1, NGA.

${ }^{66}$ Lawren Harris to Comfort, 13 August 1962, Fifth Biennial Exhibition of Canadian Painting, Vol. 6, NGA.

${ }^{67}$ Note "Fifth Biennial Trustee Opinions," 21 August 1962, Fifth Biennial Exhibition of Canadian Painting, Vol. 1, NGA.

68 "Fifth Biennial of Canadian Painting 1963: Honorary Committee", Fifth Biennial Exhibition of Canadian Painting, DOC files, NGA.

${ }^{69}$ Letter from MacKay to Comfort, 26 October 1962, Fifth Biennial Exhibition of Canadian Painting, Vol. 1, NGA.

${ }^{70}$ Harris to Comfort, 31 August 1962, Fifth Biennial Exhibition of Canadian Painting, Vol. 1, NGA.

${ }^{71}$ Letter from Pratt to Harper, 7 November 1962, Fifth Biennial Exhibition of Canadian Painting, Vol. 6, NGA.

${ }^{72}$ Letter from Hubbard to W.S.A. Dale, no date, "Observations on proposed exhibitions in London (to provide basis for discussion)", Fifth Biennial Exhibition of Canadian Painting, Vol. 2, NGA. The exhibition at the Tate Gallery became A Quarter Century of Canadian Painting 1939-63 and was on display from February 7 to March 22, 1964.

${ }^{73}$ J. Russell Harper, "The Contemporary Canadian Scene", Fifth Biennial Exhibition of Canadian Art 1963, exhibition catalogue (Ottawa: National Gallery of Canada, 1963), 3.

${ }^{74}$ Mr. Harper's Travel Schedule for Biennial, October 1962, Fifth Biennial Exhibition of Canadian Painting, Vol. 6, NGA.

${ }^{75}$ I say apparently because there is no document detailing from whom Harper received information on Bugden. Letter from Harper to Bugden, 4 December 1962, Fifth Biennial Exhibition of Canadian Painting, Vol. 2, NGA.

${ }^{76} 1963$ Packing List, Fifth Biennial Exhibition of Canadian Painting, Vol. 4, NGA.

${ }^{77}$ Harper, "The Contemporary Canadian Scene", 3.

${ }^{78}$ Charles Comfort, "Foreword", Fifth Biennial Exhibition of Canadian Art 1963, exhibition catalogue (Ottawa: National Gallery of Canada, 1963), 1.

${ }^{79}$ Harper, "The Contemporary Canadian Scene", 3.

${ }^{80}$ Ibid., 5. 
${ }^{81}$ Janice Seline, "J. Russell Harper - The Writing of History", Vanguard 13, no. 8 (October 1984): 27-28.

${ }^{82}$ Ibid., 4-5.

${ }^{83}$ Ibid., 4.

${ }^{84}$ See Anita Lahey, "From Realist to Visionary?" Vernissage (Fall 2009): 18.

${ }^{85}$ Russell Harper, "A Painter in the Maritimes," from the exhibition catalogue accompanying Jack Humphrey: A Retrospective Exhibition, organized by the Beaverbrook Art Gallery and circulated by the National Gallery of Canada, (Fredericton: Beaverbrook Art Gallery, between 1970-1976):13-14.

${ }^{86}$ Smart, The Art of Fred Ross, 47-61.

${ }^{87}$ Ibid., 59.

${ }^{88}$ Harper, "The Contemporary Canadian Scene", 3-5.

${ }^{89}$ Christopher Pratt, Ordinary Things: A Different Kind of Voyage, 27-28.

${ }^{90}$ Ibid., 27.

${ }^{91}$ Ibid., 28.

92 "Prairie Artists", Leader Post (Regina), 19 June 1963, Fifth Biennial Exhibition of Canadian Painting DOC files, NGA.

${ }^{93}$ Paul Duval, "Un-palette-able Platitudes", Saturday Night (29 July 1963): 13 N, Fifth Biennial Exhibition of Canadian Painting DOC files, NGA.

${ }^{94}$ Carl Weiselberger, "Talks about art: How the English critics reacted to Canadian paintings in London", The Ottawa Citizen, 29 June 1963, Fifth Biennial Exhibition of Canadian Painting DOC files, NGA.

${ }^{95}$ Oswell Blakeston, "Canadian Painting: Commonwealth Institute", The Arts Review (London, England), 29 June - 13 July 1963, Fifth Biennial Exhibition of Canadian Painting DOC files, NGA. Lenore Crawford in "Showcase of Canadian Art Now on Display in London", London Free Press (16 November 1963): A praises Fraser's work and reproduced it on page B of her article.

${ }^{96}$ Letter from Panabaker to Comfort, 8 August 1962, Fifth Biennial Exhibition of Canadian Painting, Vol. 6, NGA.

${ }^{97}$ Letter from Reginald Shepherd to Harper, 6 April 1963, Fifth Biennial Exhibition of Canadian Painting, Vol. 6, NGA.

${ }^{98}$ Letters from Burton to Harper, Received 8 May 1963, Fifth Biennial Exhibition of Canadian Painting, Vol. 7, NGA.

${ }^{99}$ Bornstein to Harper, 4 April 1963, Fifth Biennial Exhibition of Canadian Painting, Vol. 7, NGA.

${ }^{100}$ Atlantic Canadian artists such as Colville, Roach, and Ross were reluctant to exhibit in the Fifth

Biennial Exhibition of Canadian Painting for these reasons. Alex Colville to R. Harper, 19 February 1963; Gerald Roach to R. Harper, 30 January 1963; Fred Ross to R. Harper, 25 April 1963, Fifth Biennial Exhibition of Canadian Painting, Vol. 6, NGA.

${ }^{101}$ Peter Trepanier, The Sixties at the National Gallery of Canada, catalogue accompanying the National Gallery of Canada Library and Archives Exhibition No. 19 (Ottawa: National Gallery of Canada, 2005),13.

${ }^{102}$ Letter from Hubbard to William Townsend, 19 May 1964, The Sixth Biennial Exhibition of Canadian Painting, Vol. 1, NGA.

${ }^{103}$ Memo from Comfort to Trustees, 14 July 1964, The Sixth Biennial Exhibition of Canadian Painting, Vol. 1, NGA.

${ }^{104}$ Letter from Comfort to Hubbard, 8 July 1964, The Sixth Biennial Exhibition of Canadian Painting, Vol. 1 , NGA.

${ }^{105}$ Letter from Townsend to Comfort, 22 August 1964, The Sixth Biennial Exhibition of Canadian Painting, Vol. 1, NGA.

${ }^{106}$ Letter from Comfort to honorary advisors, 12 August 1964, The Sixth Biennial Exhibition of Canadian Painting DOC files, NGA.

107 "Papers to which 'Biennial' Advertisement was sent", 16 August 1964, The Sixth Biennial Exhibition of Canadian Painting, Vol. 1, NGA.

${ }^{108}$ Press releases "Sixth Biennial of Canadian Painting 1965: Juror and Advisory Committee Chosen", 28 August 1964, and "Sixth Biennial of Canadian Painting 1964: Revised Schedule", 14 October 1964, The Sixth Biennial Exhibition of Canadian Painting Doc files, NGA.

${ }^{109}$ Townsend's list, 6 November 1964, The Sixth Biennial Exhibition of Canadian Painting, Vols. 3 and 13, Vol. 4, NGA. Limbos-Bomberg did not take Jeffrey Poklen into account when she tallied the New Brunswick artists in her appendix. Seven works, not six, were exhibited from Atlantic Canada. 
${ }^{110}$ Willıam Townsend's juror statement, 4-7, The Sixth Biennial Exhıbitıon of Canadıan Paintıng, Vol 4, NGA

${ }^{111}$ Ibid , 7

112 "The Arts Praırıe Outburst", Tıme, Canadıan Edıtıon, Montréal (18 June 1965), B, Sıxth Biennial

Exhibition of Canadian Paintıng 1965, The Sixth Biennial Exhıbıtıon of Canadian Paintıng Doc files, NGA

${ }^{113}$ Humphrey writes to Hubbard "to voice [his] feelıngs" about the Fourth and Fifth Biennial Exhibitions

Humphrey felt that neither exhibition was a survey of depth, with a "wide gap" demonstrated between actual achievements in Canadian art and "the results of these unsearching surveys" 26 November 1964, The Sixth Biennial Exhibition of Canadian Painting, Vol 3, NGA

114 "The Arts Prairie Outburst", Tıme, Canadian Editıon, Montréal (18 June 1965), A, Sixth Biennial Exhıbitıon of Canadian Paintıng 1965, The Sixth Bıennıal Exhıbıtıon of Canadıan Paintıng Doc files, NGA

${ }^{115}$ Willıam Townsend's juror statement (18 January 1965), 1, The Sixth Biennial Exhibition of Canadian

Painting, Vol 4, NGA

${ }^{116}$ Ibid

117 "The Arts Prairie Outburst", Tıme, A-B

${ }^{118}$ While Jarvis noted that pine trees had very little to do with contemporary Canadian art, he too yearned for a "Canadian idiom" which would function like an accent, "not put on, not obtrusive " Robert

McKeown, "Is Art Necessary", Weekend Magazıne, vol 6, no 20 (19 May 1956) 4

${ }^{119}$ Comfort, "Foreword", Sixth Biennial Exhıbitıon of Canadian Paintıng 1965, exhıbition catalogue

(Ottawa National Gallery of Canada, 1965), 3

${ }^{120}$ Memo to Ostıguy from unknown, 30 October 1963, The Sixth Biennial Exhıbıtıon of Canadian Paintıng, Vol 5, NGA

${ }^{121}$ Bell to Comfort, received 28 September 1964, 12-4-22 The Sixth Biennial Exhıbıtıon of Canadian Paintıng 7, Vol 2, NGA

${ }^{122}$ Ten Decades of Service The Natıonal Gallery of Canada, Ottawa (Ottawa The National Gallery of Canada for the Corporation of the Natıonal Museums of Canada, 1979), 20

${ }^{123}$ Jean Sutherland Boggs, "CAROT Interviews Jean Sutherland Boggs", CAROT 2, no 4 (Summer 1976)

1 Sutherland Boggs claimed to the press that an American was chosen because the National Gallery was

finally purchasing American paintıngs The link seems tenuous Gail Dexter, "Days of biennials

numbered?" Toronto Dally Star (5 July 1968), The Seventh Biennial Exhıbitıon of Canadian Paintıng Doc files, NGA

${ }^{124}$ Press release "Seventh Biennial of Canadian Paıntıng", 25 June 1968, The Seventh Biennial Exhıbıtıon of Canadian Art Doc files, NGA

${ }^{125}$ Barry Lord, "Art and Artısts It's What Isn't There That Hurts Showing”, Kitchener Waterloo Record (6 July 1968), The Seventh Biennial Exhibition of Canadian Art Doc files, NGA

${ }_{126}$ Bernadette Andrews, "The Biennial", The Telegram, Toronto (6 July 1968) 54, The Seventh Biennial Exhibition of Canadian Art Doc files, NGA

${ }^{127}$ Kay Kritzwiser, "The Biennial the fruit of a search for Canadian works", Globe and Mall (6 July 1968), The Seventh Biennial Exhıbitıon of Canadian Art Doc files, NGA

128 "Atlantic Artısts Exhıbitionısts" The Argosy Weekly, Sackvılle, New Brunswick (25 October 1968) C-

92, The Seventh Biennial Exhibition of Canadian Art Doc files, NGA Limbos-Bomberg seems not to have included Harris and Poklen in her appendix's list of works

${ }^{129}$ Ga1l Dexter, "Days of biennials numbered"

${ }^{130}$ Gail Dexter, "Days of biennials numbered?"

131 "We've outgrown biennials", Toronto Star (6 July 1968) and Gail Dexter, "Days of biennials

numbered?", The Seventh Biennial Exhibition of Canadian Art Doc files, NGA

${ }^{132}$ Barry Lord, "Art and Artists It's What Isn't There That Hurts Showing", Yves Robillard,

"L'ımagınatıon au pouvoir"' La Presse, Montréal (24 August 1968), The Seventh Biennial Exhıbitıon of

Canadian Art Doc files, NGA

${ }^{133}$ Bernadette Andrews, "The Biennial"

${ }^{134}$ Nathalıe Limbos-Bomberg, "The Ideal and the Pragmatic The National Gallery of Canada's Biennial Exhibitions of Canadian Art -1953-1968" (master's thesıs, Carleton Unıversity, 2000), 151-152

${ }^{135}$ Barry Lord, "Art and Artısts It's What Isn't There That Hurts Showing" For more on Lord's position on Canadian natıonalısm and this phenomena in general see Stephen Azzi, Walter Gordon and the Rıse of

Canadıan Natıonalısm (Montréal and Kıngston McGıll-Queen's Unıversity Press, 1999), 138 


\section{Conclusion}

This thesis began by asking: Were there precedents for Atlantic artists' underrepresentation in large survey exhibitions of contemporary Canadian art and what are the broader implications of under-representation? Held from 1953 to 1968, the biennial exhibitions of Canadian art have provided a case study through which I have tested that question. These exhibitions have demonstrated a precedent of under-representation. Indeed, the history of Atlantic Canadian inclusion in the biennial exhibitions is a complex one and although there was wavering representation over the course of its history, it is important to address the issues involved.

Rather than drawing on quantitative data, I have based my argument on a detailed survey of the region's place in the series. This approach points to complex decisions that the National Gallery organizers faced when designing the series and tailoring each exhibition to the Gallery's needs and the changing course of the institution during these decades. This survey also required an understanding of multivalent conditions governing art production and display in each of the Atlantic Provinces.

This thesis demonstrates that the region's inclusion and characterization in the biennial exhibitions was dependent on many issues originating both within the National Gallery and within the Atlantic region. As the National Gallery made efforts to align itself with the international art world and pronounce its (and the country's) arrival as a serious contributor to global discussions, Atlantic Canada took the opposite approach. The region instead linked itself with the past to encourage development. This approach failed to attract a high level of National Gallery interest in the region's contemporary art during the biennial years. 
In curatorial essays, the region's art was regularly tied to the past, with representational and traditional subjects, like landscapes and seascapes, and figurative art. Although these representational and figurative works originated from contemporary circumstances - many of which were not local but the shared human experiences of the mid-twentieth century - curators did not comment in their essays on the radically changed character of these traditional formats. Colville's and Pratt's familiar landscapes and figurative paintings, for example, bore little resemblance to the documentary views of the region and portraits of earlier generations of Atlantic Canadian artists.

Some Atlantic Canadian artists were repeatedly exhibited - albeit not nearly as many, as often, or with as many works as their counterparts in other regions - but the perennial darlings of the series were Alex Colville, Christopher Pratt, and Jack Humphrey. Although Humphrey died in 1967, the work he created during the biennial series' span did not give itself away as tied-to-the-past "Atlantic Canadian art." I would argue that, likewise, most of the artists from Atlantic Canada represented in the series did not suggest their geographic location (or ties to the past) in their art. Of those who reliably depicted their environs, such as Colville and Pratt, their unique techniques certainly differentiated their art from the art of the past.

Russell Harper, while writing his essay for the Fifth Biennial Exhibition of Canadian Painting in 1963, both highlighted what he felt was the region's refusal to let go of old modes of painting and yet bemoaned the change when he saw this happening. His words announced that the region had left the past but had not yet arrived at its future destination. While not entirely accurate, there was a ring of truth to Harper's depiction of the region's art that is discernable in hindsight. 
As Chapter 1 demonstrated, contemporary Atlantic art was championed by tenacious individuals and groups across the region's provinces which created infrastructure to support the development and exhibition of home-grown contemporary art. Universities attracted accomplished artists to teach in fine art departments and were, more often than not, home to the region's art galleries. The extent of fine arts infrastructure varied among the provinces (especially during the early 1950s) but by the late 1960s New Brunswick, Nova Scotia, Prince Edward Island, and Newfoundland had significantly augmented the educational and exhibition opportunities available in the region.

The Nova Scotia College of Art, which by the late 1960s advocated the most innovative art practices in the region and, arguably, in the country at the time, coexisted in a world where Helen Creighton continued to expound her anti-modern view of the region and tell tales of its Folk. The anti-modern history promoted by such individuals and provincial governments, while providing a substantial and much-needed economic boost to the region, surely hurt the Canadian public's understanding of the modernity of the region's artists. The majority of the literature and press surrounding Atlantic Canada's contributions to the biennial exhibitions did not contradict the impression of the region as tied to the past.

As Chapters 2 and 3 demonstrated, by the late 1950s, the National Gallery was moving confidently ahead in its mission to become a player on the international art stage. The increasing professionalization of the Gallery's staff (through the hiring of bilingual individuals, regional liaisons, and rigorously trained leaders - which culminated in the hiring of Jean Sutherland Boggs as the first director with a $\mathrm{PhD}$ ), the growing number of 
exhibitions it sent abroad, and the increased purchases of American and international modern art, confirmed the Gallery's intent to be recognized as a museum of international prestige.

The contents of the National Gallery's biennial surveys of Canadian art had to be significant enough to stand out in the contemporary international art world not only for the Gallery's purposes but for the positive reputation of the country. In this context, art identified with tradition (that is, Atlantic Canadian art) would not single the National Gallery out in an admirable way. When the Fifth Biennial Exhibition opened London in 1963, the British press called such pieces "embarrassing", a label the Gallery surely did not want to be associated with. Regardless, William Townsend, curator for the Sixth Biennial Exhibition selected seven works from the region (one more than travelled to London), attesting to the interesting and innovative work being done on the Atlantic coast. When regionalism was identified by Seventh Biennial Exhibition curator William Seitz as a positive force in Atlantic Canadian art, the stimuli and seriousness he located in Sackville - ingredients for high-quality art making - could not compete successfully for the praise he lavished on artists in highly modern cities such as Vancouver, Toronto, and Montreal.

After the installation of Garry Neill Kennedy as the Nova Scotia College of Art's new president in 1967, lingering signs of traditional art making in Atlantic Canada (in the forms of seasoned but out dated faculty and established art curricula) were shaken loose, to the protest of those who were truly entrenched in the status quo. In Kennedy's words, "this relative vacuum presented an opportunity...to make the College a centre for visual arts in its immediate region and far beyond." This opportunity brought Atlantic Canadian 
art into alignment with avant-garde movements sweeping the globe as renowned artists came to Halifax to teach and invited their colleagues to come to the city to discuss art. The first such gathering was the Halifax Conference in 1969, when twenty-five artists, including Joseph Beuys, The N.E. Thing Company (Iain and Ingrid Baxter), Richard Serra, Michael Snow, Roy Lichtenstein, Claes Oldenburg, Larry Poons, and Robert Rauschenberg, travelled to Halifax to share and debate current issues and ideas. After this event, contemporary practices moved permanently into Halifax and put the region on the international art map. ${ }^{1}$ 


\section{Endnote}

${ }^{1}$ Garry Neill Kennedy, "NSCAD and the Sixties," in Conceptual Art: The NSCAD Connection 1967-1973, ed. Bruce Barber (Halifax: Nova Scotia College of Art and Design, 2001), 21-23. 
Appendix I: Atlantic Canadian Representation in Biennial Exhibitions of Canadian Art Legend: • Exhibited O Purchased

\begin{tabular}{|c|c|c|c|c|c|c|c|c|c|}
\hline & Artist & $\begin{array}{l}\text { Annual } \\
(1953)\end{array}$ & $\begin{array}{c}\text { First } \\
(1955) \\
\end{array}$ & Second (1957) & $\begin{array}{l}\text { Third } \\
(1959) \\
\end{array}$ & Fourth (1961) & $\begin{array}{l}\text { Fifth } \\
(1963)\end{array}$ & $\begin{array}{c}\text { Sixth } \\
(1965)\end{array}$ & $\begin{array}{l}\text { Seventh } \\
(1968)\end{array}$ \\
\hline \multirow[t]{10}{*}{ NB } & Bruno Bobak (1923-) & & & & & & $\bullet$ & $\bullet$ & \\
\hline & Miller Brittain (1912-1968) & $\bullet$ & & & & & $\bullet$ & & \\
\hline & Alex Colville (1920-) & & 0 & 00 & 00 & & $\bullet$ & & $\bullet$ \\
\hline & $\begin{array}{c}\text { Norman Eastman } \\
(1931-2003)\end{array}$ & $\bullet$ & & & & & & & \\
\hline & $\begin{array}{c}\text { Lawren P. Harris } \\
(1910-1994)\end{array}$ & $\bullet$ & $\bullet$ & & & & & $\bullet$ & $\bullet$ \\
\hline & Sinclair Healy (1925-) & & - & & & & & & \\
\hline & $\begin{array}{c}\text { Jack Humphrey } \\
(1901-1967)\end{array}$ & O & $\bullet$ & O & $\bullet$ & & $\bullet$ & & \\
\hline & Jeffrey Poklen (1934-) & & & & & & & $\bullet$ & $\bullet$ \\
\hline & Fred Ross (1927-) & $\bullet$ & $\bullet$ & & & $\bullet$ & & & \\
\hline & David Samila (1941-) & & & & & & & & $\bullet \bullet \bullet \bullet \bullet$ \\
\hline \multirow[t]{8}{*}{ NS } & Robert Annand (1923-) & & $\mathrm{O}$ & & & & & & \\
\hline & Carol Fraser (1930-1991) & & & & & & $\bullet$ & $0 \bullet$ & \\
\hline & Anthony Law (1916-1996) & $\bullet$ & & & & & & & \\
\hline & $\begin{array}{c}\text { Donald C. McKay } \\
(1906-1979)\end{array}$ & $\bullet$ & & & & & & & \\
\hline & Joseph Purcell (1927-) & $\bullet$ & & & & & & & \\
\hline & Edward Pulford (1914-1944) & $\bullet$ & & & & & & & \\
\hline & $\begin{array}{c}\text { Ruth Wainwright } \\
(1902-1984)\end{array}$ & & & $\bullet$ & $\bullet$ & & & $\bullet$ & \\
\hline & LeRoy Zwicker (1906-1987) & $\bullet$ & $\bullet$ & & & & & & \\
\hline $\mathrm{PE}$ & - - & & & & & & & & \\
\hline \multirow[t]{2}{*}{ NF } & Christopher Pratt (1935-) & & & & & 0 & $\bullet$ & $\bullet$ & $\bullet$ \\
\hline & $\begin{array}{c}\text { Reginald Shepherd } \\
(1924-2002)\end{array}$ & $\bullet$ & $\bullet$ & & & & & & \\
\hline \multicolumn{2}{|c|}{ Atlantic work exhibited/purchased } & $11 / 1$ & $8 / 2$ & $4 / 3$ & $4 / 2$ & $2 / 1$ & $6 / 0$ & $7 / 1$ & $9 / 0$ \\
\hline \multicolumn{2}{|c|}{ Total work exhibited/purchased } & $77 / 8$ & $62 / 17$ & $77 / 34$ & $98 / 8$ & $91 / 16$ & $86 / 10$ & $114 / 20$ & $135 / 9$ \\
\hline
\end{tabular}




\section{Selected Bibliography}

\section{Primary Sources}

National Gallery of Canada Library and Archives:

Annual Exhibition of Canadian Painting 1953

First Biennial Exhibition of Canadian Painting

Second Biennial Exhibition of Canadian Art

Third Biennial of Canadian Art

Fourth Biennial of Canadian Art

Fifth Biennial Exhibition of Canadian Painting

Sixth Biennial Exhibition of Canadian Painting

Seventh Biennial Exhibition of Canadian Art

Board of Trustees: Minutes of Meetings

East Coast Painters

Nova Scotia Archives and Records Management, Halifax:

Bulletin of Maritime Art News

Maritime Art Association

Nova Scotia Museum of Fine Arts

Nova Scotia Society of Artists

\section{Books, Exhibition Catalogues, and Theses}

Azzi, Stephen. Walter Gordon and the Rise of Canadian Nationalism. Montreal and Kingston: McGill-Queen's University Press, 1999.

Confederation Centre Art Gallery and Museum. Charlottetown: Confederation Art Gallery, 1969.

Creighton, Helen. A Life in Folklore. Toronto: McGraw-Hill Ryerson Limited, 1975.

Dominion Bureau of Statistics. 1961 Census of Canada: General Review: Rural and Urban Population, Bulletin 7.1-2. Ottawa: The Minister of Trade and Commerce, 1963.

Drouin-Brisebois, Josée. Christopher Pratt: All My Own Work. Ottawa: National Gallery of Canada / Douglas \& McIntyre, 2005.

Dumas, Paul. Picher. Ottawa: Éditions Marcel Broquet Inc., 1981. 
Eyland,Cliff. ATQUE ARS. Catalogue essay for Tantramar City: Contemporary Painting by Mount Allison Associates, curated by Cliff Eyland, Charlotte Townsend Gault and Gemey Kelly. Sackville: Owens Art Gallery, 1989.

Gard, Peter. Helen Parsons Shepherd and Reginald Shepherd: Four Decades. St. John's: Art Gallery, Memorial University of Newfoundland, 1989. Published in conjunction with Helen Parsons Shepherd and Reginald Shepherd: Four Decades shown at the Art Gallery, Memorial University of Newfoundland.

Harvey, Andrew S. and W. Stephen Macdonald. Evaluation of the Brudenell-Mill River Tourist and Recreation Complexes Embodied in the Prince Edward Island Development Plan. Halifax: Dalhousie University Institute of Public Affairs: Regional and Urban Studies Centre, 1974.

Higgins, Benjamin. Impact of the Université of Moncton on the Regions of Moncton, Edmunston and Shippagan. Moncton: Institut Canadien de Recherche sur le Développement Régional, 1988.

Horrall, Andrew. Bringing Art to Life: A Biography of Alan Jarvis. Montreal and Kingston: McGill-Queen's University Press, 2009.

Grattan, Patricia. The Power of Place: St. Michael's Printshop and 30 Years of Printmaking in Newfoundland. St. John's: Art Gallery of Newfoundland and Labrador/St. Michael's Printshop, 2004.

Larisey, Peter. Light for a Cold Land: Lawren Harris' Work and Life - An Interpretation. Toronto: Dundurn Press, 1993.

Limbos-Bomberg, Nathalie. "The Ideal and the Pragmatic: the National Gallery Canada's Biennial Exhibitions of Canadian Art - 1953-1968." Master's thesis, Carleton University, 2000.

Litt, Paul. The Muses, the Masses, and the Massey Commission. Toronto: University of Toronto Press, 1992.

MacNeil ,Steven. Library and Archives Exhibition No. 13: Maritime Art: Canada's First Art Magazine, 1940-1943. Ottawa: National Gallery of Canada, 2002.

Montague, Susan. A Pictorial History of the University of New Brunswick. Fredericton: The University of New Brunswick, 1992.

Ord, Douglas. The National Gallery of Canada: Ideas, Art, Architecture. Montreal and Kingston: McGill-Queens University Press, 2003.

O'Neill, Mora Dianne. Paintings of Nova Scotia: From the Collection of the Art Gallery of Nova Scotia. Halifax: Art Gallery of Nova Scotia, 2004. 
Overton, James. Making a World of Difference: Essays on Tourism, Culture and Development in Newfoundland. St. John's: Memorial University of Newfoundland - Institute of Social and Economic Research, 1996.

Christopher Pratt. Exhibition catalogue accompanying exhibit, organized and circulated by Memorial University of Newfoundland, Arts and Culture Centre, 6 - 31 July 1970. St. Johns: Memorial University of Newfoundland, Arts and Culture Centre, 1970.

Pratt, Christopher. Ordinary Things: A Different Kind of Voyage. St. John's: Breakwater Books Ltd., 2009.

Christopher Pratt: Personal Reflections on a Life in Art. Introduction by David Silcox. Toronto: Key Porter Books Ltd., 1995.

Reid, Dennis. A Concise History of Canadian Painting, $2^{\text {nd }}$ ed. Toronto: Oxford University Press, 1988.

Reid, John G. Mount Alison University: A History, to 1963, Vols. I and II. Toronto: University of Toronto Press for Mount Allison University, 1984.

Kieran Simpson, Canadian Who's Who: 1985, Volume XX (Toronto: University of Toronto Press, 1985.

Smart, Tom. The Art of Fred Ross: A Timeless Humanism. Fredericton: Goose Lane Editions and The Beaverbrook Art Gallery, 1993.

Soucy, Donald and Harold Pearse. The First Hundred Years: A History of the Nova Scotia College of Art and Design. Fredericton and Halifax: University of New Brunswick and NSCAD, 1993.

Ten Decades of Service: The National Gallery of Canada, Ottawa. Ottawa: The National Gallery of Canada for the Corporation of the National Museums of Canada, 1979.

Trepanier, Peter. The Sixties at the National Gallery of Canada. Catalogue accompanying the National Gallery of Canada Library and Archives Exhibition No. 19. Ottawa: National Gallery of Canada, 2005.

Tunnell, A.L.. Canadian Who's Who: 1958-1960, Volume VIII. Toronto: University of Toronto Press, 1960.

Canadian Who's Who: 1961-1963, Vol. IX. Toronto: University of Toronto Press, 1963. 
Canadian Who's Who: 1967-1969, Vol. XI. Toronto: University of

Toronto Press, 1969.

Peter B. Waite, The Lives of Dalhousie University: Volume II: 1925-1980, The Old College Transformed. Montreal and Kingston : McGill-Queen's University Press, 1997.

Young, Deborah A. Robert Annand: A Retrospective. Exhibition catalogue. Halifax: Art Gallery of Nova Scotia, 1983.

\section{Articles}

Acadia University Art Gallery. "Permanent Collection History." Acadia University Art Gallery (Wolfville: Acadia University Art Gallery, 2010): $<$ http://gallery.acadiau.ca/Acadia_Art_Gallery/history.html>.

Alfoldy, Sandra. "Moncrieff Williamson, Maritime Regionalism, and the Dream of a National Craft Museum." Journal of Canadian Art History 28 (2007): 38-51.

Ayre, Robert. “Art in Newfoundland," Canadian Art 7, no. 1 (Autumn 1949): 18-21.

Beaverbrook Art Gallery. "50th Anniversary Celebrations": $<$ http://www.beaverbrookartgallery.org/main-e.asp?207>.

Boggs, Jean Sutherland. "CAROT Interviews Jean Sutherland Boggs", CAROT 2, no. 4 (Summer 1976): 1, 6, 8.

Buchanan, Donald. "Best Food Forward in Brussels." Canadian Art 14, no. 2 (Winter 1957): 64-67.

"Coast to Coast in Art." Canadian Art 10, no. 4 (Summer 1953): 162-168.

"Coast to Coast in Art." Canadian Art 11, no. 2 (Winter 1954): 74-77.

"Coast to Coast in Art." Canadian Art 13, no. 3 (Spring 1956): 302-205.

Dalhousie University. "The Buildings of Dalhousie University: Sir James Dunn Building." Dalhousie University Archives and Special Collections, Digital Collections: <http://www.library.dal.ca/duasc/buildings/Dunn.htm>.

Dalhousie University. "The Buildings of Dalhousie University: Dalhousie Arts Centre." Dalhousie University Archives and Special Collections, Digital Collections: $<$ http://www.library.dal.ca/duasc/buildings/ArtsCentre.htm>. 
Eyland, Cliff. "Rethinking the Rural in Contemporary Newfounland Art." In Rethinking the Rural in Contemporary Art. St. John's: Art Gallery of Newfoundland and Labrador, 1997), 5-10. Published in conjunction with Rethinking the Rural in Contemporary Newfoundland Art shown at the Art Gallery of Newfoundland and Labrador, St. John's.

Galerie d'art Louise-et-Ruben Cohen de l'Université de Moncton. "Claude Roussel." In Artothèque : Overview of Contemporary Art in Acadia (Moncton: RCIP and Galerie d'art Louise-et-Ruben Cohen de l'Université de Moncton, 2006): $<$ http://www2.umoncton.ca/cfdocs/artotheque/EN/18/Biographie.pdf $>$.

Grattan, Patricia. "Foreword." In Rethinking the Rural in Contemporary Newfoundland Art. (St. John's: Art Gallery of Newfoundland and Labrador, 1997), 4. Published in conjunction with Rethinking the Rural in Contemporary Newfoundland Art shown at the Art Gallery of Newfoundland and Labrador, St. John's.

Griswold, A. Whitney. "The Natural Allies." The Fine Arts and the University (Toronto: The MacMillan Company of Canada Limited, 1965), 1-12.

Hamilton, Bill. "Looking Into Trees Attracting Widespread Attention." The Sackville Tribune Post (13 January 2010): < http://www.sackvilletribunepost.com/Opinion /Columns/2010-01-13/article-894675/Looking-Into-Trees-attracting-widespreadattention/1>.

Harper, Russell. "A Painter in the Maritimes." From the exhibition catalogue accompanying Jack Humphrey: A Retrospective Exhibition, organized by the Beaverbrook Art Gallery and circulated by the National Gallery of Canada. (Fredericton: Beaverbrook Art Gallery, 1966), 5-15.

Harris, Lawren S. "Community Art Centres - A Growing Movement," Canadian Art 2, no. 2 (December 1944 - January 1945): 63.

Humphrey, Jack. "The Problem of the Artist in the Maritimes," Canadian Art 12, no. 2 (Winter 1955): 69-72.

Kennedy, Garry Neill. "NSCAD and the Sixties." In Conceptual Art: The NSCAD Connection 1967-1973. Ed. Bruce Barber (Halifax: Nova Scotia College of Art and Design, 2001), 20-31.

Lacroix, Laurier. "Artists' Organizations." The Canadian Encyclopedia (Historica Foundation, 2010): <http://www.thecanadianencyclopedia.com/index.cfm? $\mathrm{PgNm}=\mathrm{TCE} \&$ Params $=\mathrm{a} 1 \mathrm{ART}$ A0000340 $>$.

Lahey, Anita. "From Realist to Visionary?" Vernissage (Fall 2009): 18-23. 
Matthews, Ralph. "The Smallwood Legacy: The Development of Underdevelopment in Newfoundland, 1949-1972." Journal of Canadian Studies 13, no. 4 (1978-79): 89-106.

McKay, Ian. "Handicrafts and the Logic of 'Commercial Antimodernism': The Nova Scotia Case." In Antimodernism and Artistic Experience: Policing the Boundaries of Modernity. Ed. Lynda Jessup (Toronto: University of Toronto Press, 2001), 117-129.

-------. "Helen Creighton and the Politics of Antimodernism." In Myth and Milieu: Atlantic Literature and Culture - 1918-1939. Ed. Gwendolyn Davis (Fredericton: Acadiensis Press, 1993), 1-16.

"History and the Tourist Gaze: The Politics of Commemoration in Nova Scotia, 1935-1964.” In Atlantic Canada after Confederation. Ed. P.A. Buckner, Gail G. Campbell, and David Frank, The Acadiensis Reader, vol. 2, 3rd ed. (Fredericton: Acadiensis Press, 1999), 102-138.

------. The Quest of the Folk: Antimodernism and Cultural Selection in TwentiethCentury Nova Scotia. Montreal and Kingston: Queen's University Press, 2006.

McKeown, Robert. “Is Art Necessary?” Weekend Magazine, vol. 6, no. 20 (19 May 1956): 2-4, 36-39.

McTavish, Lianne. "Learning to See in New Brunswick, 1862-1929." The Canadian Historical Review 87, no. 4 (December 2006): 553-581.

Moore, Mavor. "No Province is an Island, Entire of Itself." The Globe and Mail (June 2, 1984).

National Gallery of Canada. "Boat in Sand by Christopher Pratt": <http://cybermuse.gallery.ca/cybermuse/search/artwork_e.jsp?mkey=6016>.

--------.LeRoy Zwicker Information Form, NGC, 2 April 1945: $<$ http://cybermuse.gallery.ca/cybermuse/servlet/imageserver?src=D09375 \&ext $=x \cdot p d f>$.

New Brunswick Museum. "Humanities Collection: Beyond New Brunswick International.” (Saint John, New Brunswick: New Brunswick Museum, 2008): $<$ http://www.nbm-mnb.ca/index.php?option=com_wrapper\&view= wrapper \&Itemid $=563>$.

"New Brunswick Museum History." (Saint John, New Brunswick: New Brunswick Museum, 2008): <http://www.nbmmnb.ca/index.php?option= com_content \&view=article \&id=59\&Itemid=251>. 
Owens Art Gallery. History (Sackville: Mount Allison University, 2010): $<$ http://www.mta.ca/owens/history/index.php $>$.

Pacey, Desmond. "Coast to Coast in Art: The Maritimes," Canadian Art 18, no. 6 (November/December 1961): 419-425.

Reid, John G. “The 1920's: Decade of Struggle." In The Challenge of Modernity: A Reader on Post-Confederation Canada. Ed. Ian McKay (Toronto: McGraw-Hill Ryerson Ltd., 1992), 246-257.

Ryder, Huia. "Contemporary Handicrafts." In Arts in New Brunswick (Fredericton: University Press of New Brunswick Ltd., 1967), 261-271.

Saskatchewan Council for Archives and Archivists. "Educational Institutions: University of Saskatchewan." Saskatchewan and the Visual Arts: an Exhibit. Online exhibition. (Saskatoon: Saskatchewan Council for Archives and Archivists, 2001): < http://scaa.sk.ca/gallery/art/educational-uofs.html>.

Scalzo, Julia. "Walter Abell: From Maritime Art to Canadian Art." Vanguard 16, no. 1 (February-March 1987): 20-23.

Scott, Charles H. and Lucy Jarvis. "Paintings from East and West." Canadian Art 6, no. 4 (Summer 1949): 167-170.

Seline, Janice “J. Russell Harper - The Writing of History", Vanguard 13, no. 8 (October 1984): 27-28.

Shadbolt, Doris: "Coast to Coast in Art: An Important Conference on Galleries and Art Education.” Canadian Art 14, no. 1 (Autumn Number, 1957): 35.

Shaw, Avery. "Painters of New Brunswick." Canadian Art 11, no. 4 (Summer 1954): 151-153.

Spalding, Jeffrey. "A Brief Foray into the World of Christopher Pratt." In Josée Drouin Brisebois Christopher Pratt: All My Own Work (Ottawa: National Gallery of Canada / Douglas \& McIntyre, 2005), 12-35.

UNB Art Centre. Fact Sheet. Fredericton: UNB Art Centre, 2010. 